\title{
Combined action of Enzyme and Metal Catalyst, applied to the preparation of D-Mannitol
}

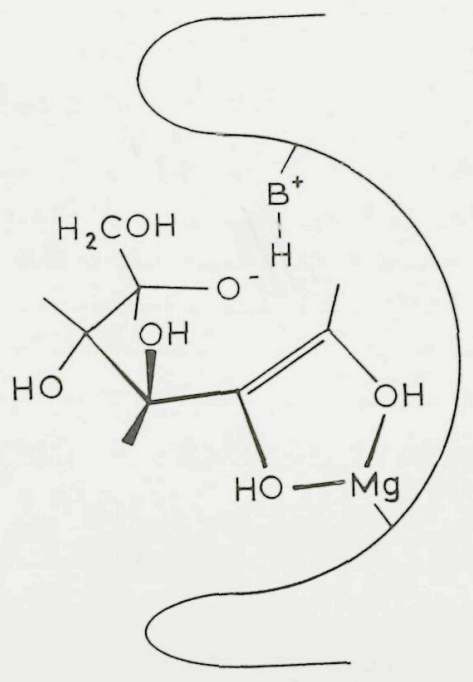

Michiel Makkee 
Combined action of Enzyme and Metal Catalyst, applied to the preparation of D-Mannitol 


\section{Combined action of Enzyme and Metal Catalyst, applied to the preparation of D-Mannitol}

\section{Proefschrift}

Ter verkrijging van de graad van doctor in de technische wetenschappen aan de Technische Hogeschool Delft, op gezag van de Rector Magnificus, prof.ir. B.P.Th. Veltman,

in het openbaar te verdedigen ten overstaan van het College van Dekanen op

dinsdag 4 december 1984 te 16.00 uur

door

Michiel Makkee geboren te 's-Gravenhage scheikundig ingenieur 
DIT PROEFSCHRIFT KWAM TOT STAND

ONDER LEIDING VAN

PROF.DR.IR. H. VAN BEKKUM, PROMOTOR,

DR.IR. A.P.G, KIEBOOM

\section{STRI.IINGEN}

1. Hoschke c.s, beweren ten onrechte dat modificatie van het actieve centrum van enzymen de evenwichtsligging van een reactie kan verschuiven.

A. Hoschke, K. Balogh, E. László en J. Holló, Starch 35 (1984) 26.

2. De conclusie van Bock C.s. dat $B-D$-fructofuranose de reactieve fructosevorm is voor het enzym glucose-isomerase (E.C. 5.3.1.5) is niet juist.

K. Bock, M. Meldal, B. Meyer en L. Wiebe, Acta Chem. Scand. B 37 (1983) 101

Dit proefschrift, Hoofdstuk 6 .

3. De verklaring van Weiss c.s. dat de vorming van saccharinezuren uit suikers in alkalisch milieu plaats vindt door middel van complexe cross-Cannizzaro reacties is niet juist.

A.H. Weiss, R.F. Socha, V.A. Likholobov en M.M. Sakharov, Chemtech. 1980,643 .

4. De verklaring yan Baust c.s, dat het niet elueren van ureum van gesulfoneerd polystyreen-divinylbenzeen in de calciumvorm bij $90^{\circ} \mathrm{C}$ te wijten is aan sterke complexering is onwaarschijnlijk.

J.G. Baust, R.E. Lee, R.R. Rojas, D.L. Hendrix, D. Friday en H. James, J. Chromatogr. 261 (1983) 65

5. In kinetische modellen voor de alkalische afbraak van glucose en fructose wordt de isomerisatie naar en de afbraak van psicose ten onrechte buiten beschouwing gelaten.

C. Kooyman, K. Vellenga en H.G.J. de Wilt, Carbohydr. Res. 54 (1977) 33 G. de Wit, A.P.G. Kieboom en H. van Bekkum, Carbohydr. Res. 74 (1979) 157. 
6. Bij het gebruik van glucose-isomerase voor de productie van glucose/fructose-stropen wordt te weinig rekening gehouden met het feit dat de mutarotatiesnelheid van glucose de snelheidsbeperkende stap kan zijn.

Gist Brocades N.V., Datasheet Maxazyme GI-Imonob., Mgi-02-01/83.03.En.05. Novo Industri A.S., Datasheet Sweetzyme Q, B 174d-GB 2000, Aug. 1981. Miles Kali-Chemie A.G., Datasheet Optisweet 22, Advances in the Enzymatic Processing of the Starch Industry.

7. De veronderstelling van Wisniak en Simon dat het inactief $2 i j n$ van een Raney-nikkel katalysator in de hydrogenering van fructose het gevolg is van productinhibitie is niet erg plausibel.

J. Wisniak en R. Simon, Ind. Eng. Chem. Prod. Res. Dev. 18 (1979) 50.

8. De aanpassing van het toetsenbord van telefoontoestellen aan dat van rekenmachines zou het gebruikersgemak vergroten.

9. In plaats van de luchtweerstandscoëfficiënt $C_{W}$ dient $C_{W}$ * (frontaaloppervlak) als maat voor de stroomlijn van auto's te worden gehanteerd. Ter informatie van de gebruiker is voorts de mat $C_{W}$ * (frontaaloppervlak)/(inwendig nuttig volume) aan te bevelen.

10. Met het toelaten van betaalde coaches als speler aan de Nederlandse cricketcompetitie heeft het bondsbestuur slechts één van de beoogde doelstellingen bereikt.

Koninkli,jke Nederlandse Cricket Bond, Beleidsnota' 80.

11. De door de kabelnetexploitant geleverde ontvangstkwaliteit van diverse buitenlandse radio- en televisiezenders rechtvaardigt (nog) niet verhoging van de abonnementsgelden ter voldoening van auteursrechten van het aangeboden materiaal. 
1. INTRODUCTION

References

2. PRODUCTION METHODS DF D-MANNITOL

Application and production

Alternative D-mannitol procedures

(i) D-giucose

(ii) D-fructose

(iii) D-mannos

(iv) D-mannose and D-fructose

Conclusions

References

3. HYDROGENATION OF D-FRUCTOSE AND D-FRUCTOSE/D-GLUCOSE

Introduction

Experimental

Matemials

Apparatus

Procedure

Analysis method

Results and discussion

Catalyst sereening

Additives

Kinetics of the D-fructose hydrogenation

Mechanism of the D-fructose hydrogenation over copper

Effect of borate addition

Mechanism of the aldose hydrogenation over copper

Conclusions 
4. INTERACTION OF BORATE WITH D-MANNITOL, D-GLUCITOL, D-FRUCTOSE AND D-GLUCOSE

Introduction

Experimental

Results and discussion

Interaction of borate anions with diols

Interaction of borate anions with D-mannito

Interaction of borate anions with D-glucitol

Interaction of borate anions with D-fructose

Interaction of borate anions with D-glucose

Effect of borate in the D-fructose hydrogenation

\section{Conclusions}

\section{Acknowledgements}

References

5. GLUCOSE ISOMERASE AND ITS BEHAVIOUR UNDER HYDROGENATION CONDITIONS

\section{Introduction}

\section{Literature survey of glucose isomerase}

History

Glucose isomerase and its mechanism of isomerization Conmercially available immobilized glucose isomerase Properties of imobilized glucose isomerase

\section{Experimental}

Materials

Apparatus

Procedure

Analysis method

Calculation of enzyme activity

\section{Results and discussion}

D-Glucose/D-fructose equilibrium constant

Hydrogen pressure

The influence of $\mathrm{Mg}(I T)$ and $\mathrm{Ca}(I I)$

The influence of some transition metal ions

Borates as additive

The influence of sugar alcohols

The influence of immobilized glucose isomerase on the

hydrogenation catalysts
6. MECHANISM OF THE ENZYMATIC ISOMERIZATION OF D-GLUCOSE AND D-FRUCTOSE

Introduction

\section{Results and discussion}

Experimental

Acknowledgements

References

7. COMBINED ACTION OF ENZYME AND METAL CATALYST, APPLIED TO THE PREPARATION OF D-MANNITOT

Introduction

Experimental

Materials
Apparatus
Procedure

Analysis method

Results and discussion

Glucose isomerase entrapped in cell material

Glucose isomerase immobilized on silica

D-Glucose as starting material

Conclusions

Acknowledgements

References

8. HPLC ANALYSIS OF REACTION MIXTURES CONTAINING MONOSACCHARIDES AND ALDITOLS

Introduction

Cation exchange resins in carbohydrate HPLC-analysis

Experimental

Apparatus

Chromatographic conditions

Materials

column preparation 


\section{Results and discussion}

The influence of the particle size of the cation exchange resin

The influence of temperature and flow rate on the capacity factor and the efficiency

Practical chromatographic conditions chosen

\section{Acknowledgements}

References

SUMMARY

1. INTRODUCTION 


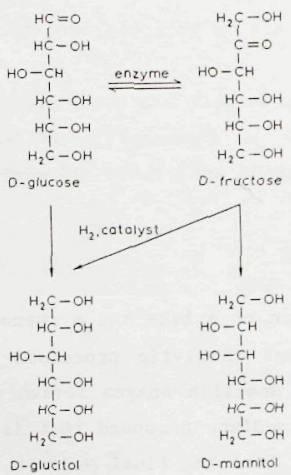

Scheme I. Combi-process: simultaneous enzymatic isomerization and metal catalyzed hydrogenation of D glucose/D-fructose mixtures.

Optimal D-mannitol formation in this 'combi-process' requires (i) preferential hydrogenation of D-fructose with respect to D-glucose, (ii) selectivity towards D-mannitol in the D-fructose hydrogenation, (iii) relatively fast $\mathrm{D}-\mathrm{glucose} \rightleftharpoons$ D-fructose interconversion in order to maintain the $D$-fructose concentration at a maximum, and (iv) minimum interference of the two catalytic species, including their different demands for sufficient activity.

It will be demonstrated that these requirements may indeed be fulfilled to a large extent by an appropriate choice of metal catalyst and reaction conditions. The experiments performed in the search for a selective hydrogenation catalyst are described in Chapter 3. It was found that copper is the most suitable catalyst metal for the required selective hydrogenation of $D$-fructose in the presence of D-glucose. The D-mannitol/D-glucitol ratio obtained upon hydrogenation of D-fructose proved to be satisfactory (0.67) for a silica-supported copper catalyst, but could be improved substantially upon addition of small amounts of borate to the hydrogenation formulation. The mechanism of the copper catalyzed hydrogenation has been studied in detail. The selectivities observed can be understood by the preferential and stereoselective hydrogenation of furanose ring structures.

In order to gain further insight in the positive effect of borate anions on D-mannitol formation from D-fructose, the complexation of borate with D-glucose, D-fructose, D-mannitol, and D-glucitol has been investigated in more detail (Chapter 4). Particularly NMR techniques proved to be valuable in the study of borate-sugar and borate-alditol esters.

Also, we had to find out whether immobilized glucose isomerase remained sufficiently active under applicable hydrogenation conditions. The results of this study and a survey of the behaviour and properties of glucose isomerase are given in Chapter 5.

The mechanism of the enzymatic isomerization of D-glucose and D-fructose, accomplished by the enzyme glucose isomerase, is described in Chapter 6.

on the basis of the above-mentioned work concerning the bio- and chemo-catalyst, i.e. immobilized glucose isomerase and supported copper, respectively, the behaviour of the two catalysts in a single batch procedure has been investigated (Chapter 7). Mutual poisoning of enzyme and metal catalyst could be largely avoided by a proper choice of reaction conditions and fornulation. This resulted an enhanced yield of D-mannitol (65\%) as compared to the present industrial process ( $30 \%)$.

Throughout this investigation, high performance liquid chromatography (HPLC) was used as the analytical technique. After some modification of procedures reported in the literature, it proved to be a rapid and reproducible quantitative analytical tool (Chapter 8).

\section{References}

1. M. Makkee, A.P.G. Kieboom, H. van Bekkum, and J.A. Roels, J. Chem. Soc., Chem. Commun. 1980, 930.

2. M. Makkee, A.P.G. Kieboom, H. van Bekkum, and J.A. Roels, Abstracts of Papers, 29th IUPAC Congress, Cologne (1983) 434. 
2. PRODUCTION METHODS OF D-MANNITOL*

Application and production

D-Mannitol is a valuable nutritive sweetener, because it is non-hygroscopic in its crystalline form ${ }^{1}$ and has no teeth decaying effects ${ }^{2}$. Up to a daily intake of $10-20 \mathrm{~g}$ D-mannitol shows no laxative properties $^{1,3}$.

$$
\begin{aligned}
& \mathrm{H}_{2} \mathrm{C}-\mathrm{OH} \\
& \mathrm{H}-\mathrm{CH} \\
& \mathrm{HO}-\mathrm{C} \\
& \mathrm{HO}-\mathrm{CH} \\
& \mathrm{H} \\
& \mathrm{HC}-\mathrm{OH} \\
& \mathrm{H}-\mathrm{OH} \\
& \mathrm{H}-\mathrm{OH} \\
& \mathrm{I} \\
& \mathrm{H}_{2} \mathrm{C}-\mathrm{OH} \\
& \text { D-mannitol }
\end{aligned}
$$

Fig. 1. D-Mannitol.

Due to these properties, D-mannitol is used as a sweet builder in 'sugar-free' chewing gum and pharmaceutical preparations. In the latter application, it masks the unpleasant taste of drugs and shows a higher mechanical strength and stability ${ }^{1}$.

The commercial production of D-mannitol (ca. 6000 ton in 1978$)^{4}$ takes place by high pressure hydrogenation of $1: 1$ D-glucose/D-fructose mixtures with Raney-Nickel as the catalyst. In the hydrogenation reaction the D-mannitol source is D-fructose which gives rise to D-glucitol and D-mannitol upon hydrogenation:

\footnotetext{
* Accepted for publication in 'Starch'.
} 


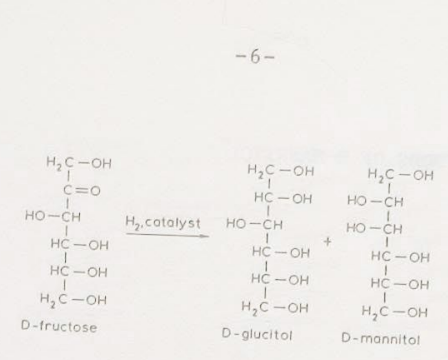

Fig. 2. Hydrogenation of D-fructose.

Due to the chirality of D-fructose the D-mannitol/D-glucitol ratio on specific molecto may vary depending genation reaction ${ }^{5}$.

Concomitantly, the D-glucose part of the mixture is converted into D-glucitol:

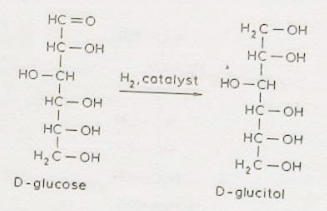

Fig. 3. Hydrogenation of D-glucose.

The starting D-glucose/D-fructose mixture is obtained either by hydrolysis of sucrose (using the enzyme invertase as the catalyst as carried out by CCA-Biochem, Gorinchem, of D-glucose (using the enzyme The Netherlands ${ }^{6}$ ) or by the isomerization formed by poqueting the enzyme glucose isomerase as the catalyst as perconsists of aquette Frères, Lille, France ${ }^{7}$ ). The hydrogenation product solution. per liter water at $\left.25{ }^{\circ} \mathrm{C}\right)$ as solubility of D-mannitol in water $(220 \mathrm{~g}$ per liter water at $\left.25^{\circ} \mathrm{C}\right)$ as compared to that of D-g1ucitol $(2350 \mathrm{~g}$ liter water at $25^{\circ} \mathrm{C}$ ), D-mannitol can be obtained by fract (2350 $\mathrm{g}$ per lization ${ }^{1,8}$. The filtrate is concentrated by fractional crystalD-glucitol solution process is summarized in sche some D-mannitol. The D-mannitol schemes, roughly correspond to parts of the compounds on a weight base.

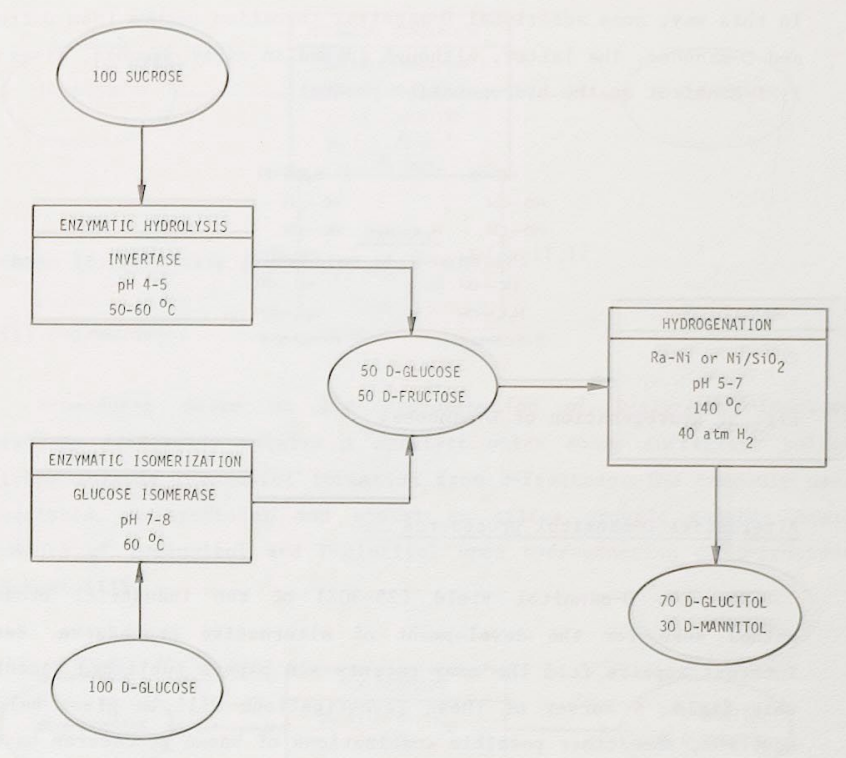

Scheme I. Commercial production of D-mannitol, using isoglucose invert sugar as starting material ${ }^{6,7}$.

It has to be mentioned that the industrial hydrogenation step is of ten carried out in two stages at different $\mathrm{pH}^{4}, 9,10$. During the first stage (at neutral pH) D-fructose hydrogenation takes place preferentially. Then the $\mathrm{pH}$ of the reaction mixture is made slightly alkaline by addition of calcium hydroxide in order to induce partial isomerization of D-glucose into D-fructose and D-mannose:

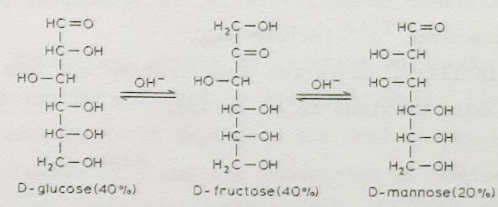

Fig. 4. Alkaline isomerization of D-glucose. 
In this way, some additional D-mannitol formation occurs from D-fructose and $D$-mannose. The latter, although formed in minor amounts, gives solely D-mannitol as the hydrogenation product:

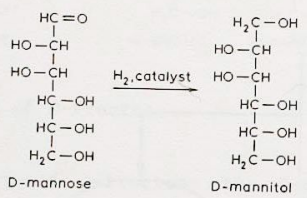

Fig. 5. Hydrogenation of D-mannose.

\section{Alternative D-mannitol procedures}

The low D-mannitol yield (25-30\%) of the industrial production method asks for the development of alternative procedures. Research interest appears from the many patents and papers published recently in this field. A survey of these investigations will be given below. In addition, some other possible combinations of known procedures have been included. The various procedures have been divided into four categories, based on the species which are reduced towards D-mannitol:
(i) D-glucose
(ii) D-fructose
(iii) D-mannose
(iv) D-mannose + D-fructose

(i) D-glucose

Direct conversion of D-glucose into D-mannitol is, of course, the most straightforward manner. This is, in principle, possible using fermentative procedures ${ }^{11,12}$ (Scheme II).

Enzyme stability, co-factor regeneration and the required reaction time are the main problems to be solved.

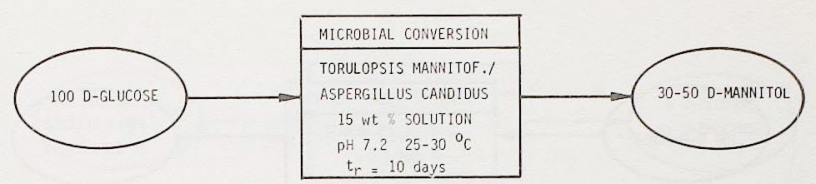

Scheme II. Fermative production of D-mannitol 11,12 .

(ii) D-fructose

Procedures based on the hydrogenation of D-glucose/D-fructose mixtures preferably require a catalyst which shows sufficient selectivity towards D-mannitol formation from D-fructose. The commonly used catalysts, Raney-Nickel and nickel on silica provide roughly equal amounts of D-mannitol and D-glucitol upon hydrogenation of D-fructose (Scheme III).

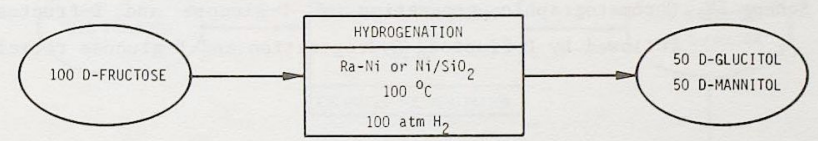

Scheme III. Hydrogenation of D-fructose towards D-mannitol.

Also higher group VIII metals were found to give the same selectivity $(40-50 \%)^{5}$. However, as described by Dewing et al. ${ }^{13}$ and in this thesis 5 (Chapter 3) copper catalysts show a substantially higher selectivity (65-90\%). Consequently, the D-mannitol yield of the various processes discussed below using Raney-Nickel or nickel on silica as the catalyst can be increased by ca. $30 \%$ if copper is used as the hydrogenation catalyst.

Very high D-fructose syrups as starting material for the hydrogenation reaction can be obtained by different ways, i.e. chromatographic separation ${ }^{15}$, conversion of D-glucose via D-glucosone into D-fructose ${ }^{16}$, hydrolysis of inulin ${ }^{17-19}$ and via conversion of D-glucose into poly-Dfructose 20,21 . The conversion schemes are given in Schemes IV, V, VI, and VII and in Figs. 6 and 7. 
$-10-$

$-11-$

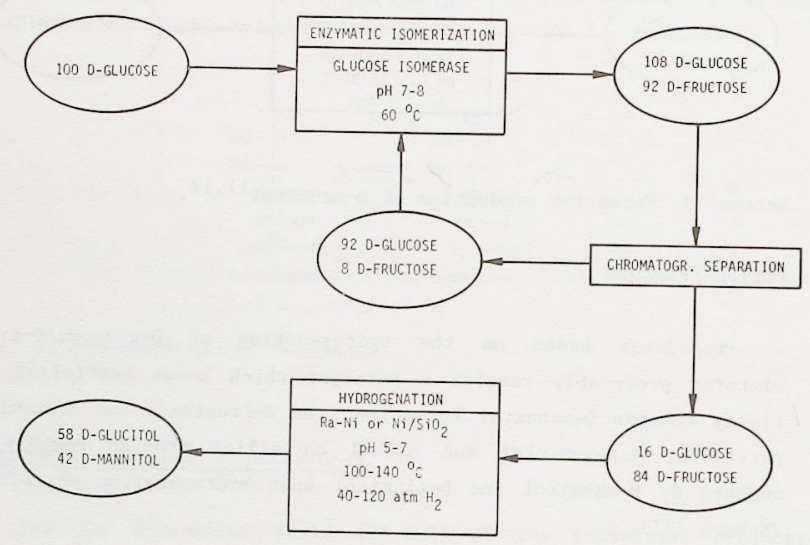

Scheme IV. Chromatographic separation of D-glucose and D-fructose ${ }^{15}$, followed by D-fructose hydrogenation and D-glucose recycling.

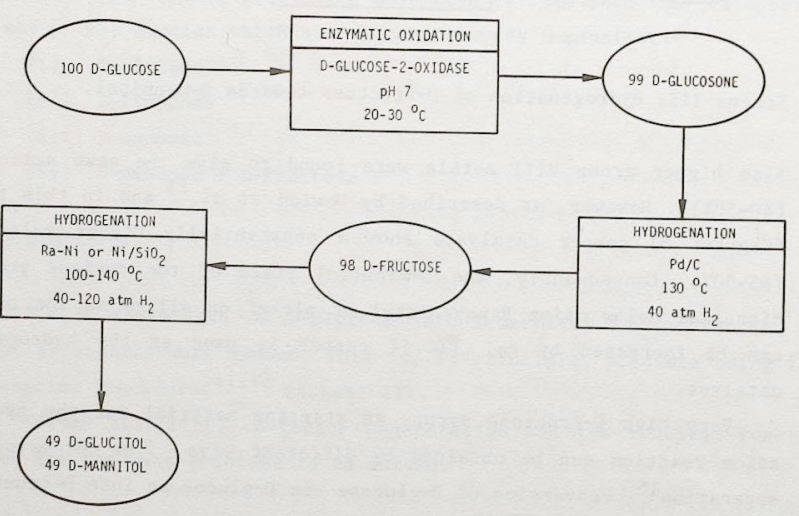

Scheme V. Production of D-fructose, according to Cetus Corp. ${ }^{16}$, followed by hydrogenation.

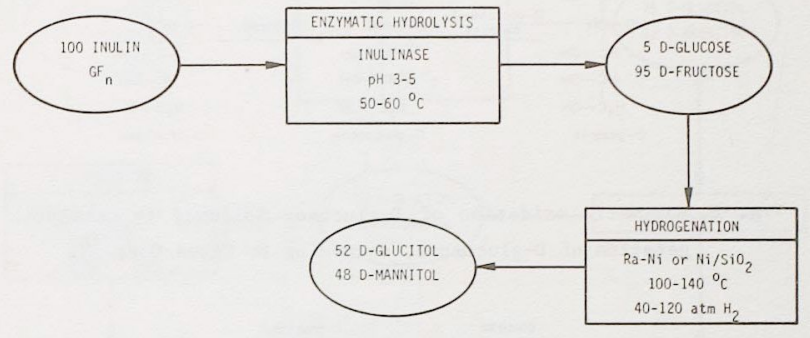

Scheme VI. Enzymatic hydrolysis of inulin ${ }^{17-19}$, followed by hydrogenation.

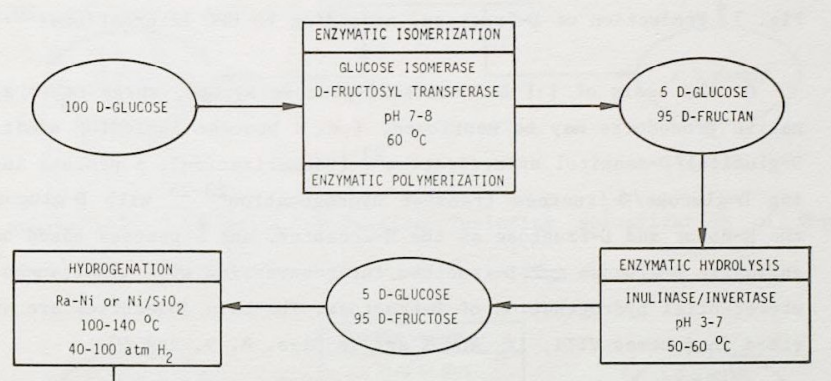

Scheme VII. Conversion of D-glucose via poly-D-fructose into D-mannitol. 


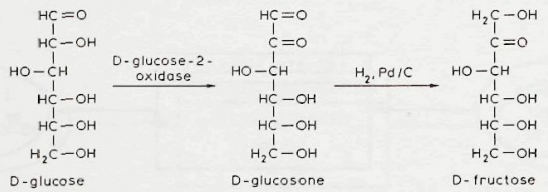

Fig. 6. Enzymatic oxidation of D-glucose, followed by catalytic hydrogenation of D-glucosone, according to Cetus Corp. ${ }^{16}$.

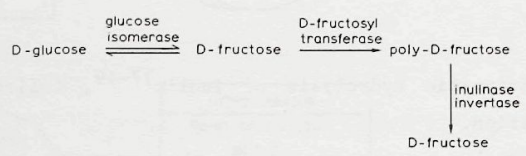

Fig. 7. Production of D-fructose, according to CPC International20,21.

On the basis of 1:1 D-fructose/D-glucose syrups, three other alternative procedures may be mentioned, $i . e$. a process including additional D-glucitol/D-mannitol epimerization ${ }^{22}$ (isomerization), a process involving D-glucose/D-fructose transfer hydrogenation ${ }^{23-25}$ with D-glucose as the H-donor and D-fructose as the H-acceptor, and a process based on the enzymatic D-glucose $\rightleftharpoons \mathrm{D}$-fructose interconversion with simultaneous and preferential hydrogenation of $D$-fructose. The main objectives are summarized in Schemes VIII, IX, and $\mathrm{X}$ and in Figs. 8, 9, and 10 .

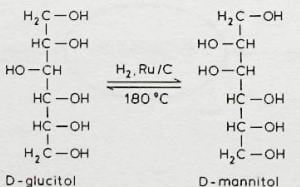

Fig. 8. Epimerization of D-glucitol towards D-glucitol/D-mannitol mixtures $^{22}$.

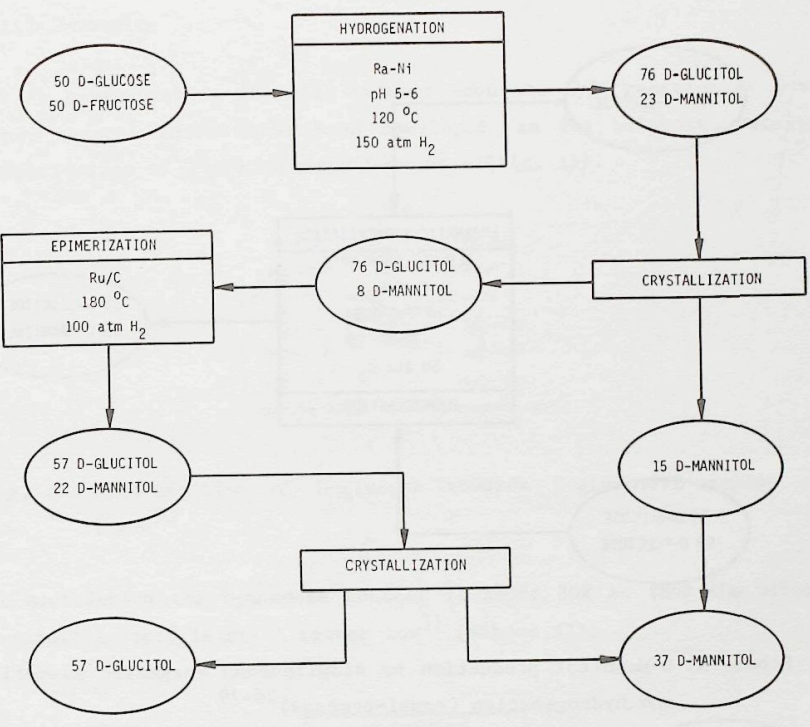

Scheme VIII. D-Mannitol production including epimerization of D-glucitol ${ }^{22}$.

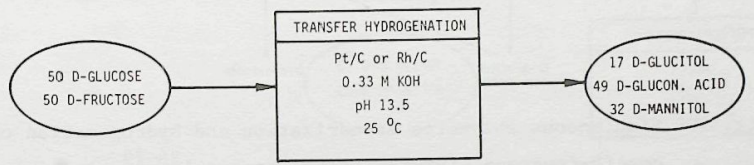

Scheme IX. D-Mannitol production by transfer hydrogenation of invert sugar ${ }^{23-25}$.

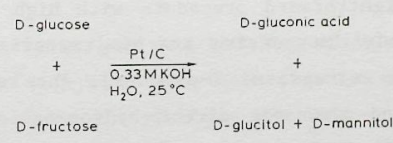

Fig. 9. Transfer hydrogenation of D-glucose/D-fructose mixtures ${ }^{23-25}$. 


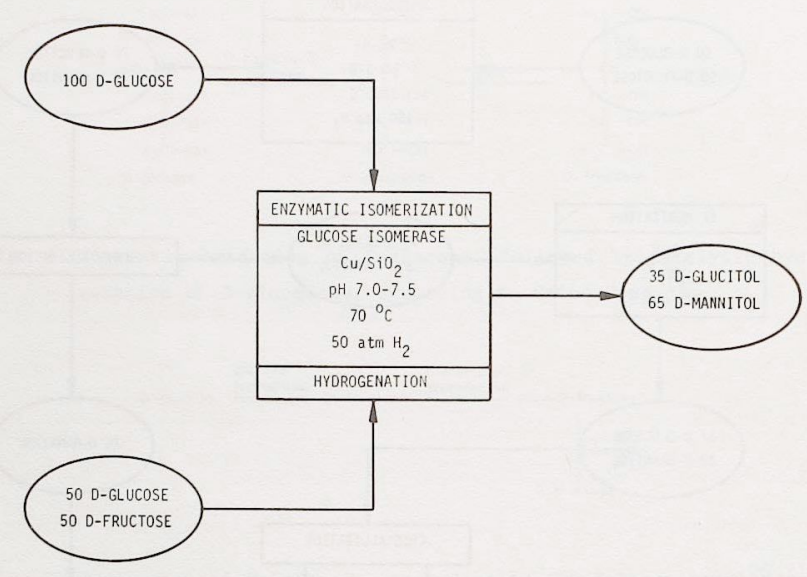

Scheme $\mathrm{X}$. D-Mannitol production by simultaneous enzymatic isomerization and hydrogenation (combi-process) $26-29$.

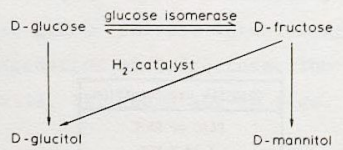

Fig. 10. Simulaneous enzymatic isomerization and hydrogenation of D-glucose/D-fructose mixtures (combi-process) $26-29$.

Comparison of the procedures mentioned above for $D$-fructose as the D-mannitol precursor show that the combi-process (Scheme $X$ ) is by far the most straightforward procedure with high D-mannitol yield, thereby using relatively inexpensive starting materials (invert sugar, D-glucose/D-fructose syrups, or D-glucose). The route starting from inulin (Scheme VI) and that via direct hydrogenation of D-glucosone into a D-mannitol/D-glucitol mixture (Scheme V) seem also promising.

\section{(iii) D-mannose}

As D-mannitol is the sole product upon the hydrogenation of D-mannose, several routes have been developed via the molybdate catalyzed epimerization of D-glucose into D-mannose (Fig. 11).

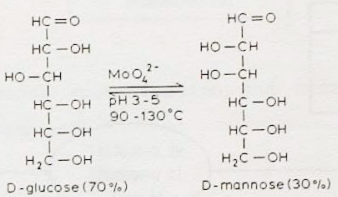

Fig. 11. Epimerization of D-glucose towards D-glucose/D-mannose mixtures $^{30}$.

At equilibrium the D-mannose content is about $30 \%$ so that the ultimate D-mannitol yield is still rather low $^{31}$ (Scheme XI).

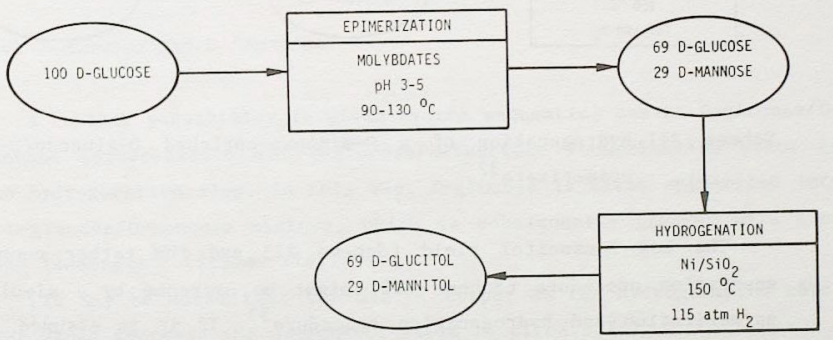

Scheme XI. Epimerization of D-glucose into D-mannose, followed by hydrogenation ${ }^{30}$.

Increase of the D-mannitol yield has been accomplished by the introduction of a separation step after the epimerization reaction. Selective D-glucose-NaCl adduct formation yields a D-mannose-enriched D-mannose/Dglucose solution, which upon hydrogenation gives circa $50 \%$ D-mannitol ${ }^{32}$ (Scheme XII). 


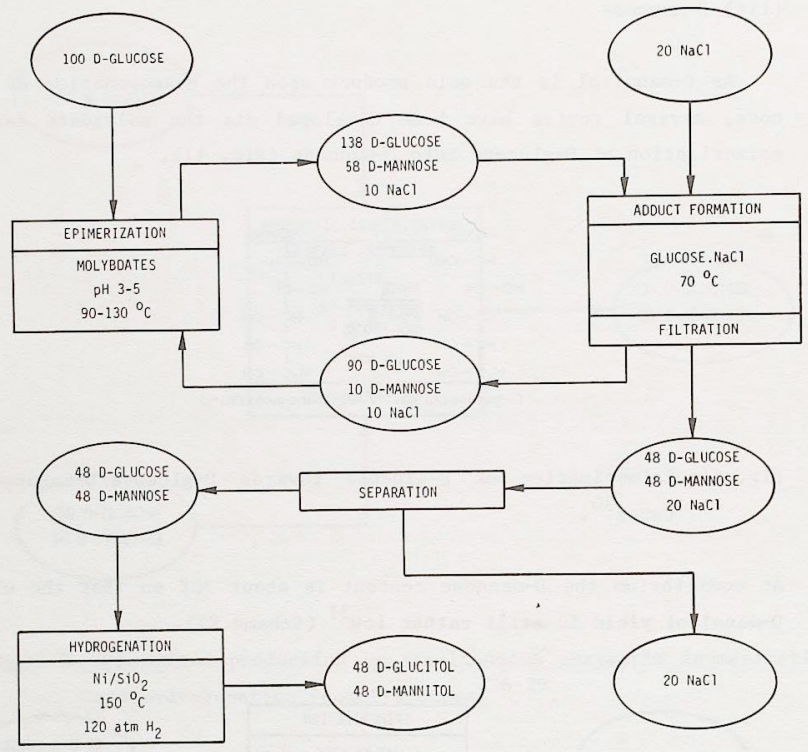

Scheme XII. Hydrogenation of a D-mannose-enriched D-glucose/D-mannose epimerizate ${ }^{32}$.

The low D-mannitol yield (Scheme XI) and the rather complicated separation procedure (Scheme XII) might be overcome by a simultaneous epimerization and hydrogenation procedure ${ }^{33}$. If it is assumed that no serious interference occurs between the epimerization catalyst (molybdate) and the hydrogenation catalyst. Taking into account the preferential D-mannose hydrogenation (by a factor 2) as found by us ${ }^{34}$ for D-mannose/D-glucose mixtures over a number of conventional hydrogenation catalysts, a D-mannitol yield of ca. $45 \%$ would be expected (Scheme XIII and Fig. 12).

Such a combined procedure would seem of importance if a more selective hydrogenation catalyst can be developed.

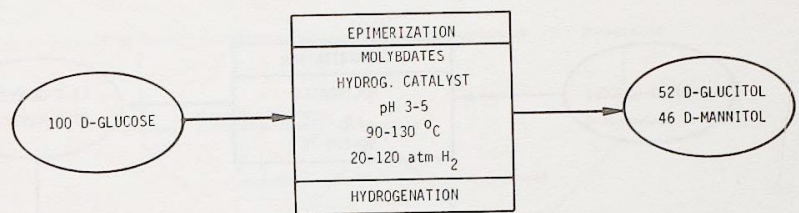

Scheme XIII. Simultaneous epimerization and hydrogenation of D-glucose and D-mannose.

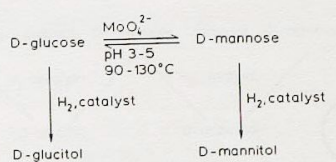

Fig. 12. Simultaneous epimerization and hydrogenation of D-glucose/Dmannose mixtures ${ }^{33}$.

(iv) D-mannose and D-fructose

A further possibility is given by the sequential use of D-glucose/Dmannose epimerization and D-g1ucose/D-fructose isomerization prior to the hydrogenation step. In this way, D-glucose is first epimerized into a cose isomerase ${ }^{35}$ (Scheme XIV).

(It may be noted that the use of copper as the hydrogenation catalyst would increase the D-mannitol yield to circa $55 \%$.)

Simultaneous enzymatic isomerization and hydrogenation in this procedure will further increase the D-mannitol yield. Such a procedure, which has not yet been experimentally verified, is depicted in Scheme XV and Fig. 13.

Another possibility is the simultaneous interconversion and hydrogenation of $D$-glucose/D-fructose/D-mannose mixtures which, in principle, could be attractive (Fig. 14). 

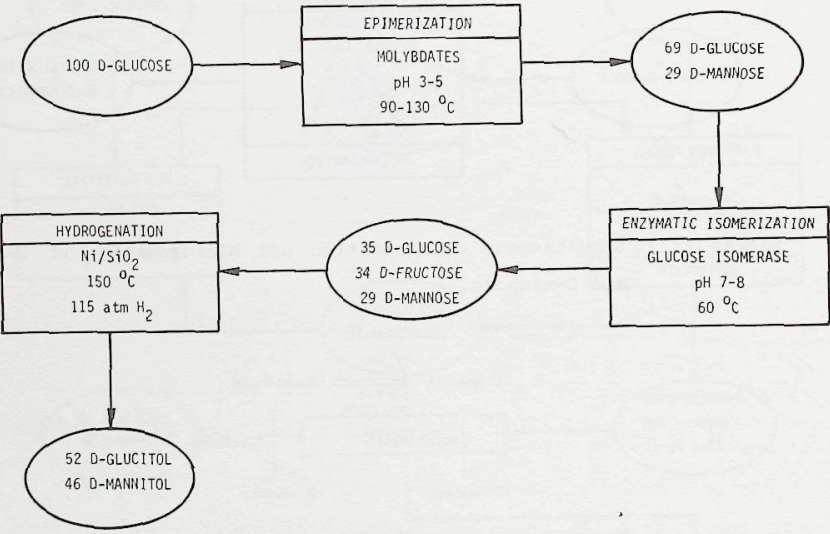

Scheme XIV. D-Mannitol production from D-glucose by sequential epimerization, isomerization and hydrogenation ${ }^{35}$.

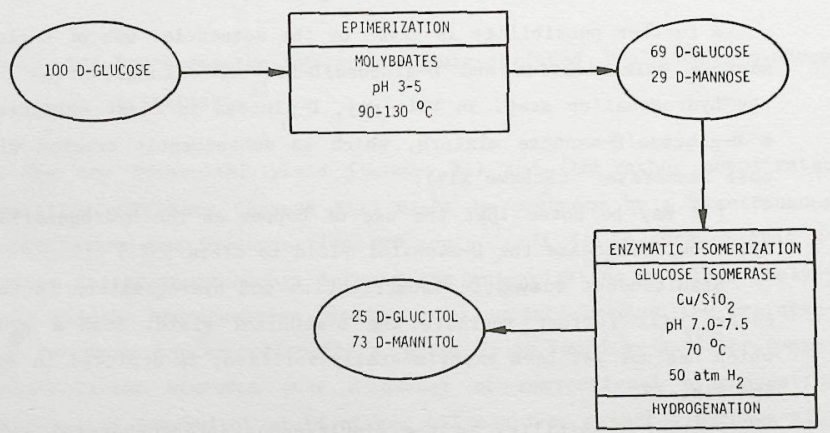

Scheme XV. Epimerization of D-glucose, followed by the combi-process procedure.

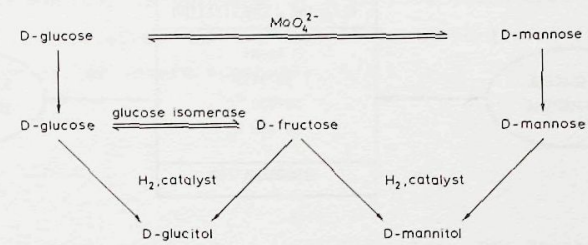

Fig. 13. Combination of epimerization and combi-process procedure.

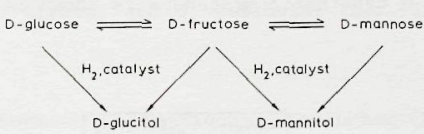

Fig. 14. Simultaneous D-glucose/D-fructose/D-mannose isomerization and hydrogenation ${ }^{9}, 10$.

Two examples of concomitant alkaline isomerization and hydrogenation are given in Scheme XVI (starting from D-glucose ${ }^{36}$ ) and scheme XVII (with a D-glucose/D-fructose mixture as feedstock ${ }^{9,10}$ ). Only partial isomerization is attainable, however, since otherwise substantial amounts of alkaline degradation products will be formed. So, the increase in D-mannitol yield is Iimited, due to the non-availability of proper catalyst for the D-glucose/D-mannose/D-fructose isomerization.

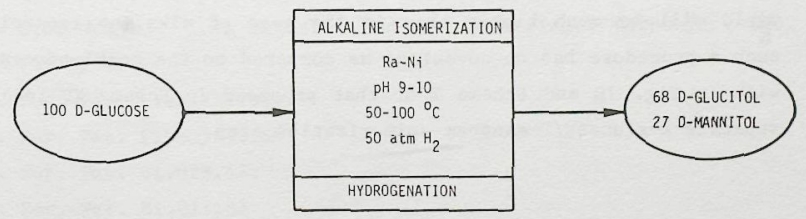

Scheme XVI. Alkaline isomerization and hydrogenation of D-glucose 36 


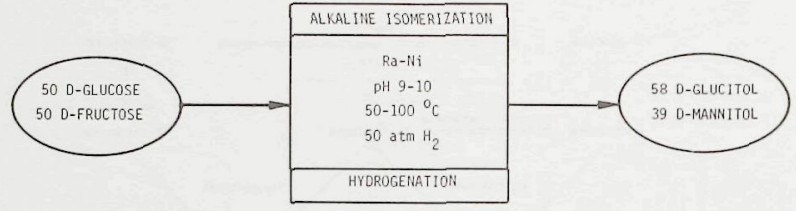

Scheme XVII. Alkaline isomerization and hydrogenation of isoglucose or invert sugar $^{9}, 10$

For comparison, a hypothetic procedure is shown in scheme XVIII.

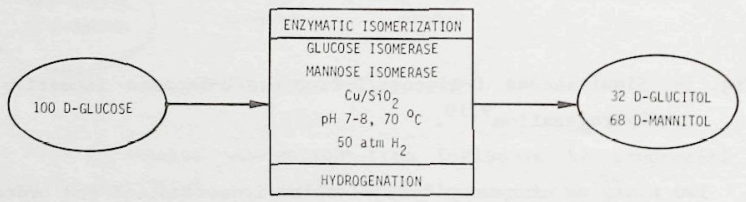

Scheme XVIII. Super combi-process procedure, using glucose isomerase, mannose isomerase and $\mathrm{Cu} / \mathrm{SiO}_{2}$ as catalysts.

Here, it is assumed that the action of two (known) isomerases ${ }^{37}$ keeps the $\mathrm{D}$-glucose/D-fructose/D-mannose mixture in equilibrium during the hydrogenation reaction. Using the results as found by $\mathrm{us}^{5,26,34}$, the D-mannitol yield will be approximately $65 \%$. Although the D-mannitol yield will be much higher than in the case of alkaline isomerization, such a procedure has no advantage as compared to the combi-process dealt with in Fig. 10 and Scheme $X$ or that proposed in Scheme XV involving a separate $D$-glucose/D-mannose epimerization step.

\section{Conclusions}

A comparison of all of the above mentioned procedures allows the conclusion that the combi-process (Scheme $\mathrm{X}$ ) is the most promising and straightforward procedure in the preparation of D-mannitol. High yield
(65\%) of D-mannitol is obtained in a one-pot procedure, thereby using relatively inexpensive starting materials as D-glucose, D-glucose/Dfructose syrups, or invert sugar.

\section{References}

1. Sorbitol \& Mannitol, Product Information, CCA-Biochem, Gorinchem (The Netherlands).

2. J.H. Shaw and D. Griffiths, J. Dental Res. 39 (1960) 377.

3. F.W. Ellis and J.C. Krantz, J. Biol. Chem. 141 (1941) 151.

4. R. Albert, A. Sträte, and G. Vollheim, Chem.-Ing.-Tech. 52 (1980) 582 .

5. Chapter 3.

6. Production Information, CCA-Biachem, Gorinchem (The Netherlands).

7. Production Information, Roquette Frères, Lille (France).

8. U.S. Pat. (1972) 3,632,656.

9. U.S. Pat. (1967) 3,329,729

10. U.S. Pat. (1973) 3,763,246.

11. U.S. Pat. (1969) 3,427,224.

12. U.S. Pat. (1971) 3,622,456.

13. Eur. Pat. (1980) 6313.

14. Eur. Pat. (1980) 20048.

15. H.W. Keller, A.C. Reents, and J.W. Laraway, Starch 33 (1981) 55.

16. Eur. Pat. (1981) 28136. In this process the hydrogen peroxide which is formed together with D-glucosone in the enzymatic oxidation of D-glucose is used for epoxidation of alkenes.

17. L. Zittan, Starch 33 (1981) 373.

18. S.J. Angyal, G.S. Bethell, and R.J. Beveridge, Carbohydr. Res. 73 (1979) 9.

18. Eur. Pat. (1981) 11350

19. Eur. Pat. (1982) 43169

20. Eur. Pat. 81.026 .42 .

21. Eur. Pat. 81.015 .87

22. Jpn. Pat. (1974) 26602.

23. G. de Wit, J.J. de Vlieger, A.C. Kock-van Dalen, R. Heus, R. Laroy, A.J. van Hengstum, A.P.G. Kieboom, and H. van Bekkum, Carbohydr. Res. 91 (1981) 125. 
24. G. de Wit, J.J. de Vlieger, A.C. Kock-van Dalen, A.P.G. Kieboom, and H. van Bekkum, Tetrahedron Lett. 1978, 1327.

25. A.J. van Hengstum, A.P.G. Kieboom, and H. van Bekkum, Starch, in press.

26. Chapter 7.

27. M.Makkee, A.P.G. Kieboom, H. van Bekkum, and J.A. Roels, J. Chem. Soc., Chem. Commun. 1980, 930.

28. M. Makkee, A.P.G. Kieboom, H. van Bekkum, and J.A. Roels, Abstracts of Papers, 29th IUPAC Congress, Cologne (1983) 434.

29. J.F. Ruddlesden and A. Stewart, J. Chem. Res. (S) 1981, 378 ,

30. M.L. Hayes, N.J. Pennings, A.S. Serianni, and R. Barker, J. Am. Chem. Soc. 104 (1982) 6764.

31. U.S. Pat. (1977) 4,029,878.

32. Eur. Pat. (1983) 74713.

33. B.F.M. Kuster, Eindhoven University of Technology, private communication.

34. M. Makkee, A.P.G. Kieboom, and H. van Bekkum, unpublished results.

35. U.S. Pat. (1979) 4,173,514.

36. H.C.M. Pynenburg, B.F.M. Kuster, and H.S. van der Baan, Starch 30 (1978) 199.

37. N.J. Palleroni and M. Doudoroff, J. Biol. Chem. 218 (1956) 535.

\section{HYDROGENATION OF D-FRUCTOSE AND D-FRUCTOSE/D-GLUCOSE MIXTURES*}

\section{Introduction}

Hydrogenation of D-glucose yields D-glucitol whereas D-fructose yields a mixture of D-glucitol and D-mannitol. From this one can understand why D-mannitol is about three times as expensive as D-glucitol. However, apart from its nice sweet taste and non-carious properties, D-mannitol is in a more favourable position for various applications due to its non-hygroscopicity ${ }^{1-4}$.

In our search for an alternative procedure for the preparation of D-mannitol, we have developed the combi-process depicted in Fig. $1^{1-3}$.

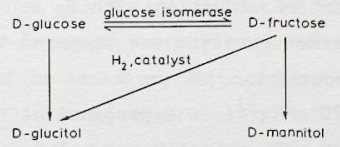

Fig. 1. Combi-process: simultaneous enzymatic isomerization and metal catalyzed hydrogenation of D-glucose/D-fructose mixtures.

Optimal D-mannitol formation requires a hydrogenation catalyst with the following properties:

(i) sufficient activity at conditions dictated by the enzyme species $\left(\mathrm{T}=60-70{ }^{\circ} \mathrm{C}, \mathrm{pH}=6 \cdot 5-8 \cdot 0\right)^{5}$;

(ii) preferential hydrogenation of D-fructose with respect to D-glucose;

(iii) selectivity towards D-mannitol for the D-fructose hydrogenation.

\footnotetext{
* Accepted for publication in 'Carbohydrate Research'.
} 
In this connection we have studied the behaviour of a series of In this con chereof. As supported copper appeared to be the catalyst of choice, the mechanism and kinetics of the copper-catalyzed liquid phase hydrogenation of monosaccharides have been investigated in more detail, including the effect of certain additives.

\section{Experimental}

Materials

D-Glucose, D-fructose, D-mannose, D-talose, D-glucitol, D-mannitol, D-Glucose, D-fructose, Dere supplied , magnesium chloride and by Merck. Copper nitrate, magnesium sulfate, magnesium chloride and ammonium bicarbonate were obtained from Baker. Isomaltulose was a gift from Süddeutsche Zucker A.G. The catalysts 5\% ruthenium, 5\% palladium, $5 \%$ rhodium and $5 \%$ platinum on carbon were obtained from briffhout Amsterdam. The $10 \%$ iridium on carbon catalyst was prepared by impregnation of activated carbon (Degussa, $770 \mathrm{~m}^{2} \cdot \mathrm{g}^{-1}$ ) with iridium trichloride (Alfa) followed by reduction with $\mathrm{H}_{2}$ at $300{ }^{\circ} \mathrm{C}$ and $\mathrm{l}$ atm for $3 \mathrm{~h}$. The $5 \%$ osmium tetraoxide (Drijfhout) in the presence of a suspension of activated Carbon (Degussa, $770 \mathrm{~m}^{2} \cdot \mathrm{g}^{-1}$ ) in 2-propanol at $60{ }^{\circ} \mathrm{C}$ and 100 atm hydrogen pressure for $2 \mathrm{~h}$. The $5 \%$ ruthenium on calcium carbonate was prepared by impregnation of calcium carbonate with a solution of ruthenium trichloride (Alfa) in acetone, followed by reduction with $\mathrm{H}_{2}$ at $60{ }^{\circ} \mathrm{C}$ and 1 atm for 3 h $60 \%$ Nickel on silica and Raney Nickel B $115 \quad Z$ were obtained from Strem Chemicals and Degussa, respectively. All the above mentioned catalysts were used without prior treatment. The $20 \%$ copper on silica catalyst was prepared according to the literature ${ }^{6}$ with some modifications in the reduction step for which the following procedure was used. The dried catalyst precursor was treated with $10 \% \mathrm{H}_{2}$ and $90 \% \mathrm{~N}_{2}$ at 1 atm and heated from $25{ }^{\circ} \mathrm{C}$ to $400{ }^{\circ} \mathrm{C}$ for $1 \mathrm{~h}$, heated at $400{ }^{\circ} \mathrm{C}$ for $3 \mathrm{~h}$, and heated from stored under nitrogen. The active cooled on silica amounted to $80-100 \mathrm{~m}^{2} \cdot \mathrm{g}^{-1} \mathrm{Cu}$, as determined by the dissociation of $\mathrm{N}_{2} \mathrm{O}$. The B.E.T. surface of the silica was $290 \mathrm{~m}^{2} \cdot \mathrm{g}^{-1} \mathrm{SiO}_{2}$ (as determined by $\mathrm{N}_{2}$ adsorption).

\section{Apparatus}

The hydrogenations were carried out in a $450 \mathrm{ml}$ Hastelloy B autoclave model 4562, manufactured by Parr. The autoclave was equipped with a motor-driven impeller stirrer, a sampling device and two needle valves. The autoclave was thermostatted by a water bath.

Procedure

The catalyst and the additives were transferred into the aqueous solution of the carbohydrate to be hydrogenated. The autoclave was sealed, flushed with hydrogen and placed in the water bath. After reaching the required temperature the autoclave was pressurized with hydrogen to the required level. The reaction was started by switching on the stirrer. The conversion was followed by HPLC analysis of samples withdrawn from the reaction mixture.

Analysis method

The HPLC system consisted of an M 6000 A pump (Waters Assoc.), a Rheodyne 7125 injector, an $\mathrm{R} 401$ differential refractometer (Waters Assoc.) and a cation-exchange resin column. Chromatographic conditions; column dimensions: $30 \mathrm{~cm} * 7.0 \mathrm{~mm}$ ID; Aminex A $78 \%$ cross-linked resin $(7-11 \mathrm{\mu m})$ in the $\mathrm{Ca}(\mathrm{II})-\mathrm{form}$; temperature: $85{ }^{\circ} \mathrm{C}$; flow rate: $0.6 \mathrm{ml} / \mathrm{min}$; eluent: degassed and deionized $\mathrm{H}_{2} \mathrm{O}$. The chromatographic procedure is described in more detail elsewhere ${ }^{7}$.

\section{Results and discussion}

Catalyst screening

The hydrogenation of D-glucose, D-fructose and a $1: 1 \quad$ D-glucose/Dfructose mixture were carried out in aqueous solution at $\mathrm{pH} 6-8,60-70$ ${ }^{\circ} \mathrm{C}$, and 20-50 atm $\mathrm{H}_{2}$ with eight different catalyst metals.

Table I shows the catalysts used together with their initial activity for invert sugar (D-glucose/D-fructose $1: 1$ ) hydrogenation. As for most of these catalysts no metal surfaces have been determined these data only give an impression of the metal surface activity. 
Two selectivities have been used in the screening of these hydrogenation catalysts:

(i) selectivity towards D-mannitol formation from D-fructose:

$$
S_{\text {D-mannitol }}=\frac{\text { D-mannitol formed }}{D \text {-fructose converted }}
$$

(ii) selectivity towards $D$-fructose conversion in $1: 1$ D-glucose/D-fructose mixtures:

$$
S_{\text {D-fructose }}=\frac{D-f \text { ructose converted }}{(D-f \text { ructose }+D-g \text { lucose }) \text { converted }}
$$

\section{TABLE I}

Catalytic activities of metal catalysts used for invert sugar hydrogenation $^{a}$

\begin{tabular}{ll}
\hline Catalyst & Initial rate $\left(\mathrm{mol} \cdot \mathrm{h}^{-1} \cdot \mathrm{g}_{\text {metal }}{ }^{-1}\right.$ ) \\
\hline $100 \%$ Raney Nickel & 0.1 \\
$60 \%$ Nickel on silica & 0.04 \\
$20 \%$ Copper on silica & 0.3 \\
$5 \%$ Ruthenium on carbon & 1.9 \\
$5 \%$ Ruthenium on calcium carbonate & 1.4 \\
$5 \%$ Rhodium on carbon & 0.3 \\
$5 \%$ Palladium on carbon & 0.3 \\
$5 \%$ Osmium on carbon & 1.6 \\
$10 \%$ Iridium on carbon & 0.8 \\
$5 \%$ Platinum on carbon & 1.9 \\
\hline
\end{tabular}

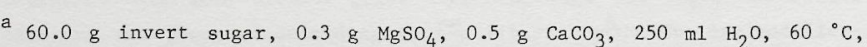
$20 \mathrm{~kg} / \mathrm{cm}^{2} \mathrm{H}_{2}$.

The results are shown in Fig. 2.

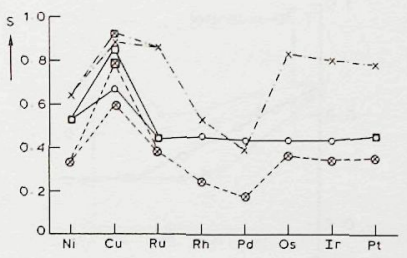

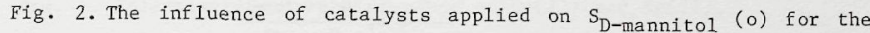
D-fructose hydrogenation, on $S_{D}$-fructose $(x)$ for the invert sugar hydrogenation, and on the overall yield (Q) of D-mannitol in the combi-process.

(o) $30.0 \mathrm{~g} \mathrm{D}$-fructose, $250 \mathrm{ml} \mathrm{H} \mathrm{H}_{2} \mathrm{O}, 60{ }^{\circ} \mathrm{C}, 20 \mathrm{~kg} / \mathrm{cm}^{2} \mathrm{H}_{2}, 0.5 \mathrm{~g}$ catalyst;

(x) $60.0 \mathrm{~g}$ invert sugar, $250 \mathrm{ml} \mathrm{H} \mathrm{H}_{2} \mathrm{O}, 60{ }^{\circ} \mathrm{C}, 20 \mathrm{~kg} / \mathrm{cm}^{2} \mathrm{H}_{2}, 1.0 \mathrm{~g}$ catalyst;

(Q) $\mathrm{S}_{\mathrm{D} \text {-fructose }} \times \mathrm{S}_{\mathrm{D} \text {-mannitol; }}$

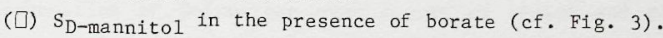

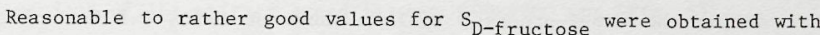
copper on silica, ruthenium on carbon, osmium on carbon and platinum on carbon. Rhodium on carbon shows no preference whereas in the case of palladium on carbon D-glucose was preferentially hydrogenated. $\mathrm{S}_{\mathrm{D} \text {-mannitol }}$ proved to be rather independent of the metal catalyst applied, except for copper on silica which showed a rather high selectivity towards D-mannitol (0.67). This selectivity can be further improved to 0.85 by adding of borate as illustrated in Fig. 3. In addition, $S_{D-f r u c t o s e}$ for copper on silica was slightly enhanced (from 0.88 to 0.92 ) in the presence of borate.

Obviously, the copper on silica is the catalyst of choice for D-mannitol formation. Application in the combi-process should allow a D-man-

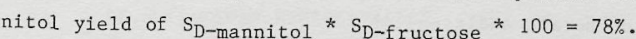




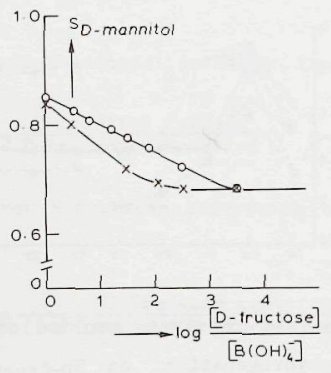

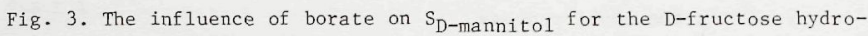
genation over copper on silica.

$30.0 \mathrm{~g}$ fructose, $250 \mathrm{ml} \mathrm{H} \mathrm{H}_{2} \mathrm{O}, 70{ }^{\circ} \mathrm{C}, 50 \mathrm{~kg} / \mathrm{cm}^{2} \mathrm{H}_{2}, 1.0 \mathrm{~g} 20 \%$ $\mathrm{Cu} / \mathrm{SiO}_{2}$ without $(0)$ and in the presence $(\mathrm{x})$ of $0.5 \mathrm{~g} \mathrm{CaCO}_{3}$.

\section{Additives}

In order to keep the enzyme glucose isomerase sufficiently active during the combi-process, small amounts of $\mathrm{CaCO}_{3}$ (as buffering agent) and $\mathrm{Mg}$ (II) (as enzyme stabilizing agent) have to be added to the hydrogenation mixture. These additives had no serious effect on the activity of the metal catalysts. Furthermore, $S_{D-f r u c t o s e}$ remained essentially the same, whereas $S_{D-m a n n i t o l}$ increased fractionally, especially for platinum on carbon (Fig. 4).

The addition of borate to the hydrogenation formulation with copper on silica as catalyst had a positive effect on the selectivity towards D-mannitol (Fig. 3). The effect is somewhat less pronounced when Ca(II) and $\mathrm{Mg}$ (II) are present. The other catalysts showed no increase in $\mathrm{S}_{\mathrm{D} \text {-mannitol }}$ upon borate addition. The borate/copper phenomenon will be discussed below (the mechanism of the D-fructose hydrogenation over copper, effect of borate addition).

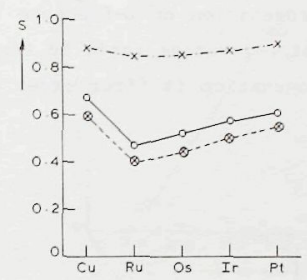

Fig. 4. Selectivities in the presence of $\mathrm{Ca}(\mathrm{II})$ and $\mathrm{Mg}(\mathrm{II})$.

$S_{\text {D-mannital }}$ (o) $30.0 \mathrm{~g}$ D-fructose, $0.3 \mathrm{~g} \mathrm{MgSO}_{4}, 0.5 \mathrm{~g} \mathrm{CaCO}_{3}$, $250 \mathrm{ml} \mathrm{H} \mathrm{H}_{2} \mathrm{O}, 60^{\circ} \mathrm{C}, 20 \mathrm{~kg} / \mathrm{cm}^{2} \mathrm{H}_{2}, 0.5 \mathrm{~g}$ catalyst.

$\mathrm{S}_{\mathrm{D}-\mathrm{f} \text { ructose }}$ ( $\mathrm{x}$ ) $60.0 \mathrm{~g}$ invert sugar, $0.3 \mathrm{~g} \mathrm{MgSO}_{4}, 0.5 \mathrm{~g} \mathrm{CaCO}_{3}$, $250 \mathrm{ml} \mathrm{H} \mathrm{H}_{2} \mathrm{O}, 60^{\circ} \mathrm{C}, 20 \mathrm{~kg} / \mathrm{cm}^{2} \mathrm{H}_{2}, 1.0 \mathrm{~g}$ catalyst.

$\mathrm{S}_{\mathrm{D}-\text { fructose }} \times \mathrm{S}_{\mathrm{D}-\mathrm{mannitol}}$ : (Q)

Kinetics of the D-fructose hydrogenation

Hydrogenation of D-fructose over copper on silica and platinum on carbon at various agitation rates showed that the reaction rate was independent of the stirrer speed between 800-1200 rpm (Fig. 5).

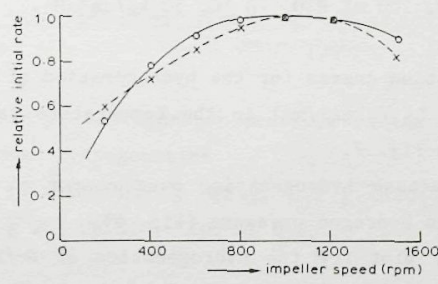

Fig. 5. The influence of the impeller speed on the relative initial rate of $D$-fructose hydrogenation.

$30.0 \mathrm{~g}$ D-fructose, $0.3 \mathrm{~g} \mathrm{MgSO}_{4}, 0.5 \mathrm{~g} \mathrm{CaCO}_{3}, 250 \mathrm{ml} \mathrm{H} \mathrm{H}_{2} \mathrm{O}$ and $(\mathrm{x})$ $0.5 \mathrm{~g} 5 \% \mathrm{Pt} / \mathrm{C}, 60{ }^{\circ} \mathrm{C}, 20 \mathrm{~kg} / \mathrm{cm}^{2} \mathrm{H}_{2}$, or (o) $1.0 \mathrm{~g} 20 \% \mathrm{Cu} / \mathrm{SiO}_{2}$, $70{ }^{\circ} \mathrm{C}, 50 \mathrm{~kg} / \mathrm{cm}^{2} \mathrm{H}_{2}$. 
A stirrer speed of $800 \mathrm{rpm}$ was used throughout the experiments. The initial rate of the hydrogenation of $D$-fructose $(0.833 \mathrm{M})$ was linearly dependent on the catalyst/D-fructose ratio in the range of $0.003-0.1667$ (Fig. 6), i.e. the hydrogenation is first order in the amount of cata1yst.

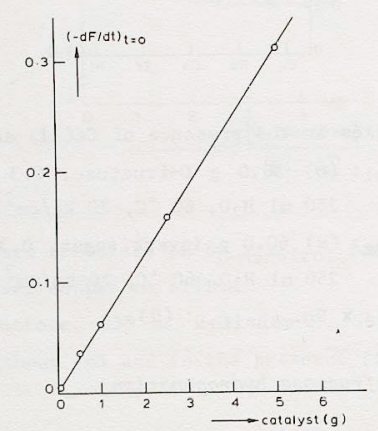

Fig. 6. The influence of the amounts of $\mathrm{Cu} / \mathrm{SiO}_{2}$ on the initial rate of D-fructose hydrogenation.

$30.0 \mathrm{~g}$ D-fructose, $0.3 \mathrm{~g} \quad \mathrm{MgSO}_{4}, 0.5 \mathrm{~g} \mathrm{CaCO}_{3}, 0.1 \mathrm{~g} \mathrm{Na}_{2} \mathrm{~B}_{4} \mathrm{O}_{7}$. $10 \mathrm{H}_{2} \mathrm{O}, 200 \mathrm{ml} \mathrm{H} \mathrm{H}_{2} \mathrm{O}, 70{ }^{\circ} \mathrm{C}, 50 \mathrm{~kg} / \mathrm{cm}^{2} \mathrm{H}_{2}$.

An activation energy for the hydrogenation of D-fructose over copper on silica of $14.7 \mathrm{kcal} / \mathrm{mol}$ in the temperature range of 60 to $90{ }^{\circ} \mathrm{C}$ is obtained from Fig. 7.

The D-fructose hydrogenation over copper on silica appeared to be first order in hydrogen pressure (Fig. 8).

A typical plot for the hydrogenation of D-fructose over copper is shown in Fig. 9. The reaction appeared to be between zero and first order in D-fructose concentration at $0.3<[F]<0.8$, zero order at $[F]$ $>0.8$ and first order at $[F]<0.3 \mathrm{M}$. This is demonstrated by the logarithmic relation between $[\mathrm{F}]$ and $\mathrm{d}[\mathrm{F}] / \mathrm{dt}$ as shown in Fig. 10 ,

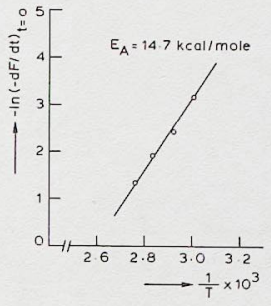

Fig. 7. Arrhenius plot of the initial reaction rates for the D-fructose hydrogenation.

$30.0 \mathrm{~g}$ D-fructose, $0.3 \mathrm{~g} \mathrm{MgSO}, 0.5 \mathrm{~g} \mathrm{CaCO}, 0.1 \mathrm{~g} \mathrm{Na}{ }_{2} \mathrm{~B}_{4} \mathrm{O}_{7} .-$ $10 \mathrm{H}_{2} \mathrm{O}, 1.0 \mathrm{~g} 20 \% \mathrm{Cu} / \mathrm{SiO}_{2}, 200 \mathrm{ml} \mathrm{H} \mathrm{H}_{2} \mathrm{O}, 50 \mathrm{~kg} / \mathrm{cm}^{2} \mathrm{H}_{2}$ at $60,70,80$ and $90{ }^{\circ} \mathrm{C}$.

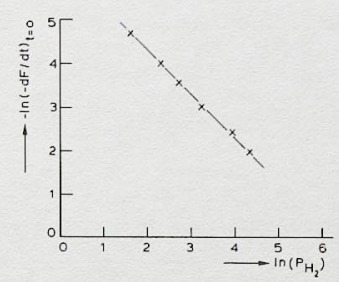

Fig. 8. The influence of the hydrogen pressure on the initial rates for the $D$-fructose hydrogenation.

$30.0 \mathrm{~g}$ D-fructose, $0.3 \mathrm{~g} \mathrm{MgSO}_{4}, 0.5 \mathrm{~g} \mathrm{CaCO}_{3}, 0.1 \mathrm{~g} \mathrm{Na}{ }_{2} \mathrm{~B}_{4} \mathrm{O}_{7} \cdot-$ $10 \mathrm{H}_{2} \mathrm{O}, 1.0 \mathrm{~g} 20 \% \mathrm{Cu} / \mathrm{SiO}_{2}, 200 \mathrm{ml} \mathrm{H} \mathrm{H}_{2} \mathrm{O}, 70{ }^{\circ} \mathrm{C}$.

The foregoing results lead to the conclusion that the rate limiting step is the hydrogen attack at D-fructose on the catalyst surface. The reaction products D-mannitol and D-glucitol did neither affect the rate of D-fructose hydrogenation as appeared from Table II, nor the stereoselectivity of this reaction. 


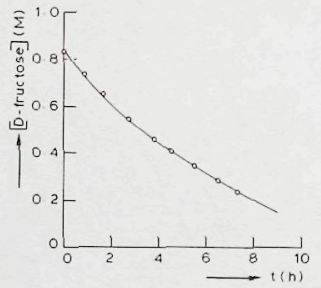

Fig. 9. Concentration versus time of a typical D-fructose hydrogenation. $30.0 \mathrm{~g}$ D-fructose, $0.3 \mathrm{~g} \mathrm{MgSO}_{4}, 0.5 \mathrm{~g} \mathrm{CaCO}, 0.1 \mathrm{~g} \mathrm{Na}_{2} \mathrm{~B}_{4} \mathrm{O}_{7} \cdot-$ $10 \mathrm{H}_{2} \mathrm{O}, 1.0 \mathrm{~g} 20 \% \mathrm{Cu} / \mathrm{SiO}_{2}, 200 \mathrm{ml} \mathrm{H} \mathrm{H}_{2} \mathrm{O}, 70{ }^{\circ} \mathrm{C}, 50 \mathrm{~kg} / \mathrm{cm}^{2} \mathrm{H}_{2}$.

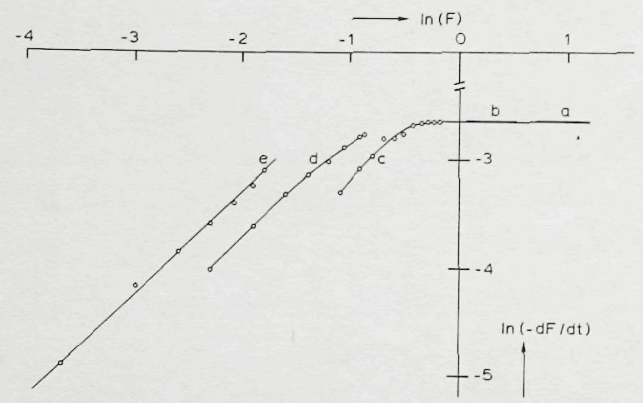

Fig. 10. The influence of the concentration of D-fructose on its initial rate of hydrogenation.

$0.3 \mathrm{~g} \mathrm{MgSO}, 0.5 \mathrm{~g} \mathrm{CaCO}, 0.1 \mathrm{~g} \mathrm{Na} 2 \mathrm{~B}_{4} \mathrm{O}_{7} \cdot 10 \mathrm{H}_{2} \mathrm{O}, 1.0 \mathrm{~g} 20 \%$ $\mathrm{Cu} / \mathrm{SiO}_{2}, 200 \mathrm{ml} \mathrm{H} \mathrm{H}_{2} \mathrm{O}, 70{ }^{\circ} \mathrm{C}, 50 \mathrm{~kg} / \mathrm{cm}^{2} \mathrm{H}_{2}$. D-Fructose (a: 120.0 $\mathrm{g}, \mathrm{b}: 60.0 \mathrm{~g}, \mathrm{c}: 30.0 \mathrm{~g}, \mathrm{~d}: 15.0 \mathrm{~g}$, e: $6.0 \mathrm{~g}$ ).
TABLE II

Influence of D-mannitol and D-glucitol on the rate of the D-fructose hydrogenation

Composition

Initial rate $\left(\mathrm{mol} \cdot \mathrm{h}^{-1}\right)$

$30 \mathrm{~g}$ D-Fructose

0.044

$60 \mathrm{~g}$ D-Fructose

$30 \mathrm{~g}$ D-Fructose $+30 \mathrm{~g}$ D-Mannitol

0.04

30 \& D-Fructose + $30 \mathrm{~g}$ D-Glucitol

$30 \mathrm{~g}$ D-Fructose $+15 \mathrm{~g}$ D-Mannital $+15 \mathrm{~g}$ D-Glucitol 0.043

a $0.5 \mathrm{~g} \mathrm{CaCO} ; 0.4 \mathrm{~g} \mathrm{MgSO} ; 1.0 \mathrm{~g} 20 \% \mathrm{Cu} / \mathrm{SiO}_{2} ; 200 \mathrm{ml} \mathrm{H}_{2} \mathrm{O} ; 70{ }^{\circ} \mathrm{C}$ $50 \mathrm{~kg} / \mathrm{cm}^{2} \mathrm{H}_{2}$.

The kinetic picture observed is easily explained using LangmuirHinshelwood kinetics.

D-fructose (in solution) $\stackrel{\mathrm{b}_{\mathrm{F}}}{\rightleftharpoons} \mathrm{D}$-fructose (adsorbed) $\stackrel{\mathrm{k}}{\longrightarrow}$ products

$r=\frac{-d[F]}{d t}=k \theta_{F}=k \frac{b_{F}[F]}{1+b_{F}[F]+\angle b C}$

Here, $k$ includes the hydrogen pressure and the amount of catalyst, whilst $\Sigma \mathrm{bC}$ is the sum of the contributions of water, D-glucitol, D-mannitol and the hydrogen to the denominator of the Langmuir-Hinshelwood expression.

If $\mathrm{b}_{\mathrm{F}}[\mathrm{F}] \gg 1+\Sigma \mathrm{bC}$ then $\mathrm{r}-\mathrm{k} \quad$ (zero order in $\mathrm{D}$-f ructose),

if $b_{F}[F]<1+\Sigma b C$ then $r-k[F]$ (first order in $D$-fructose).

The selectivity towards $D$-fructose conversion in the hydrogenation of 1:1 D-glucose/D-fructose mixtures over copper on silica is determined by both the adsorption and reaction rate constants of $D$-fructose and D-glucose:

$S_{D}$-fructose $=\frac{k_{F} b_{F}}{k_{G}{ }^{b}{ }_{G}}$ 
Individual hydrogenations of D-glucose and D-fructose $(0.833 \mathrm{M})$ over copper on silica in water at $70{ }^{\circ} \mathrm{C}$ and $50 \mathrm{~atm} \mathrm{H}_{2}$ yielded $\mathrm{k}_{\mathrm{F}} / \mathrm{k}_{\mathrm{G}}=27$. Under the same conditions, the co-adsorption of $\mathrm{D}$-glucose was examined by measuring the decrease in initial rate for the $D$-fructose hydrogenation upon addition of increasing amounts of D-glucose (Fig. 11).

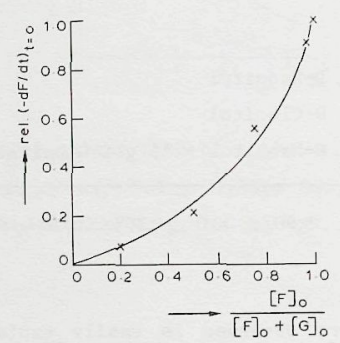

Fig. 11. The influence of D-glucose on the relative initial rate of the D-fructose hydrogenation.

$30.0 \mathrm{~g}$ D-fructose, $0.3 \mathrm{~g} \mathrm{MgSO}_{4}, 0.5 \mathrm{~g} \mathrm{CaCO}_{3}, 0.1 \mathrm{~g} \mathrm{Na}_{2} \mathrm{~B}_{4} \mathrm{O}_{7} .-$ $10 \mathrm{H}_{2} \mathrm{O}, 1.0 \mathrm{~g} 20 \% \mathrm{Cu} / \mathrm{SiO}_{2}, 200 \mathrm{ml} \mathrm{H} \mathrm{H}_{2} \mathrm{O}, 70{ }^{\circ} \mathrm{C}, 50 \mathrm{~kg} / \mathrm{cm}^{2} \mathrm{H}_{2}$.

Using $r_{0} \sim \frac{k_{F} b_{F}[F]}{b_{F}[F]_{O}+b_{G}[G]_{O}}=\frac{k_{F}[F]_{O}}{[F]_{O}+\frac{b_{G}}{b_{F}}[G]_{O}}$

it follows that $\frac{{ }^{b} G}{b}=3$, i.e. D-glucose is adsorbed more strongly than $D$-fructose. So the overall selectivity $S_{D-f r u c t o s e}=9$ observed upon hydrogenation of equimolar quantities of D-fructose and D-glucose is brought about by a 27 times higher reactivity of D-fructose, which is partly counteracted by a 3 times stronger adsorption of D-glucose.

Mechanism of the D-fructose hydrogenation over copper

In aqueous solution, D-fructose is present in four different forms:

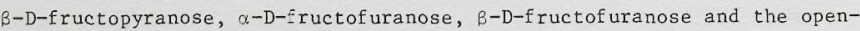
chain structure. These forms will have different strengths of adsorption on the metal surface of the hydrogenation catalyst, while each of such an adsorbed surface complex has its own rate of hydrogenation. The com- bination of adsorption strength and reactivity will determine which form of D-fructose is preferentially hydrogenated.

In addition, there are in principle three mechanistic possibilities for the hydrogenation of the carbonyl group of a ketose ${ }^{8}$ (Fig. 12):

- hydrogenation of the free carbonyl group (a);

- hydrogenation of the 1,2-enediol form (b);

- hydrogenolysis of either a pyranose or a furanose form (c).

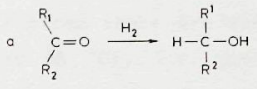

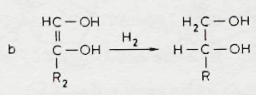

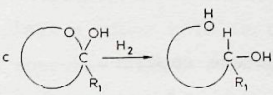

Fig. 12. Mechanistic possibilities of the D-fructose hydrogenation.
a) carbonyl hydrogenation;
b) enediol hydrogenation;
c) ring C-0 hydrogenolysis.

Possibilities $a$ and $b$ have been rejected by Ruddlesden et $a r .{ }^{8}$. These authors found no reaction of an open-chain keto-D-fructose derivative $(1,3,4,5,6$-penta-0-acetyl-2-keto-D-fructose did not show any hydrogenation whereas 1,3,4,5-tetra-0-acety1-D-fructopyranose could be hydrogenated under comparable conditions) and found only incorporation of one ${ }^{2} \mathrm{H}$ at $\mathrm{C}-2$ upon deuterogenation of $\mathrm{D}-\mathrm{f}$ ructose, respectively. The latter result has been confirmed by us: one ${ }^{2} \mathrm{H}$ at $\mathrm{C}-2$ for D-fructose $\left(\mathrm{D}_{2} \mathrm{O}\right.$, $70{ }^{\circ} \mathrm{C}, 50 \mathrm{~kg} / \mathrm{cm}^{2}$ ) and of one ${ }^{2} \mathrm{H}$ at $\mathrm{C}-1$ for both $\mathrm{D}$-glucose and $\mathrm{D}$-mannose $\left(\mathrm{D}_{2} \mathrm{O}, 100{ }^{\circ} \mathrm{C}, 50 \mathrm{~kg} / \mathrm{cm}^{2}\right)$ were present in the alditol upon deuterogenation of the monosaccharides over copper on silica. The remaining mechanistic possibility $c$, however, is also not consistent since the methyl D-fructosides are not hydrogenated under the above mentioned hydrogenation conditions. At higher temperatures $\left(120^{\circ} \mathrm{C}\right)$ and long reaction times the methyl D-fructosides were converted into methanol, D-mannitol and D-glucitol, without any 2-O-methyl-D-mannitol or 2-O-methy1-D-glucitol 
formation. Clearly, hydrogenation occurs after hydrolysis of the methyl D-fructosides into methanol and D-fructose. Any ring C-O hydrogenolysis can be ruled out. Consequently, the only possibility left will be a mechanism in which the ring structure with an ionizable anomeric hydroxy1 is the reactive species.

${ }^{13} \mathrm{C}$ NMR work on monosaccharides in this laboratory has shown that upon ionization of D-fructose the C-O ring bond is weakened and that the anomeric $\mathrm{C}^{-} \mathrm{O}^{-}$bond becomes partly of double bond character, leading to the following electronic structures for the $\beta$-pyranose and $\beta$-furanose forms ${ }^{9}$ (Fig. 13).

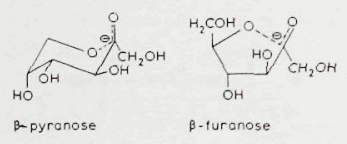

Fig. 13. Ionized D-fructose species.

It is believed that interaction of ketoses and aldoses with metals like copper may easily lead to such ionized species on the metal surface. In this way a favourable system for hydrogen attack at the anomeric carbon is obtained (transfer of a hydride-like species to the partially positive anomeric carbon, on the analogy of the mechanism proposed for the benzyl $\mathrm{C}-0$ hydrogenolysis ${ }^{10}$ ). The ring oxygen is a good leaving group in the process due to the weakened $\mathrm{C}-0$ bond. The importance of ionized species is further shown by the strongly accelerating effect of base in the hydrogenation of D-fructose over noble metals as platinum and rhodium $^{11}$. The electronic distribution in the ionized species in combination with the proposed attack of a hydride-like species favours hydrogen attack from the 'anti-ring-O' side, i.e. an $\mathrm{S}_{\mathrm{N}} 2$ type of reaction with inversion of configuration of the anomeric carbon (ef. Fig. 14). We, therefore, propose that $D$-mannitol formation occurs from the $\beta$-forms of D-fructose, whereas D-glucitol formation occurs from the $\alpha$-forms of D-fructose ${ }^{12}$.

An explanation of the diastereoselective control of the reaction needs a complete interpretation of the occurrence of the different ring forms in solution in combination with their relative adsorption strengths and reactivities. In this respect isomaltulose (6-O- $\alpha-D-g l u c o-$ pyranosyl-D-fructofuranose) is a suitable model compound since there are only two forms present (in aqueous solution at room temperature), i.e. 6-0- $\alpha-D-g 1$ ucopyranosyl- $\alpha-D-f$ ructof uranose $(20 \%)$ and $6-0-\alpha-D-g 1$ ucopyranosyl- $\beta-D-f$-fuctofuranose $(80 \%)$. If the furanose forms react with comparable rate and adsorb with comparable strength the 6-0-a-D-glucopyranosylD-mannitol/6-O- $\alpha$-D-glucopyranosyl-D-glucitol ratio should be largely determined by the $B / \alpha$ ratio of these two furanose forms in solution. This, indeed, is in accordance with the results of the hydrogenation of isomaltulose $\left(\mathrm{Cu} / \mathrm{SiO}_{2}, 100{ }^{\circ} \mathrm{C}, 50 \mathrm{~kg} / \mathrm{cm}^{2} \mathrm{H}_{2}\right)$ which gave $67 \%$ of $6-0-\alpha-\mathrm{D}-$ glucopyranosyl-D-mannitol and 33\% of 6-O- $-D-D$-glucopyranosyl-D-glucitol.

In the case of $D$-fructose there are three major ring forms present in aqueous solution (at $66^{\circ} \mathrm{C}$ ), i.e. $\beta$-D-fructopyranose $(55 \%), \quad B-D-$ fructofuranose (35\%) and $\alpha-D-f$ ructofuranose $(10 \%)$. Nevertheless, the product composition upon hydrogenation over copper on silica still corresponds with that of isomaltulose and thus resembles the $B / \alpha-D-f r u c-$ tofuranose ratio, i.e. $67 \%$ of D-mannitol and $33 \%$ of D-glucitol. The pyranose form probably plays a minor role in the hydrogenation reaction. Taking into account the somewhat higher adsorption strength of D-glucose ( $100 \%$ pyranose form) than that of $D$-fructose, the small contribution of the pyranose form of $\mathrm{D}$-fructose to the hydrogenation reaction is due to its much lower reactivity. This analysis would imply a substantially higher reactivity ratio of D-fructofuranose and D-glucopyranose than the overall ratio of 27 for D-fructose and D-glucose as given earlier in this chapter.

The phenomenon of the lower reactivity of the pyranose form in respect with the furanose form is in accordance with the results obtained by the competitive hydrogenation of $\mathrm{D}$-mannose and D-talose. D-Mannose is solely present as its pyranose forms $\left(\mathrm{H}_{2} \mathrm{O}, 31{ }^{\circ} \mathrm{C}\right)$, whereas D-talose is present for $70 \%$ in pyranose forms and for $30 \%$ in furanose forms $\left(\mathrm{H}_{2} \mathrm{O}, 44^{\circ} \mathrm{C}\right)$ (due to the extra axial $4-\mathrm{OH}$ group in the pyranose form). Competitive hydrogenation of a $1: 1 \quad$ D-mannose/D-talose mixture showed that the initial conversion of D-talose was 2.7 times higher than that of D-mannose $\left(\mathrm{Cu} / \mathrm{SiO}_{2}, 70{ }^{\circ} \mathrm{C}, 50 \mathrm{~kg} / \mathrm{cm}^{2} \mathrm{H}_{2}, \mathrm{H}_{2} \mathrm{O}\right)$.

In an analogous way the preferential hydrogenation product formation for L-sorbose, D-tagatose, D-psicose, D-xylulose and D-ribulose, as expected from their respective $\beta / \alpha$-furanose ratios in water, will be D-glucitol, D-allitol, D-talitol, D-arabinitol and D-ribitol, respectively. This, indeed, appears to be in qualitative accordance with the experimental hydrogenation results of Ruddlesden et al. ${ }^{8}$ with copper on silica as the catalyst. 
On the basis of the foregoing results and considerations we propose that the hydrogenation of $\mathrm{D}$-fructose (and other ketoses) over copper involves the following steps (cf. Fig. 14):

(i) formation of an ionized furanose ring species adsorbed on the copper surface by coordination of $0-1,0-2$ and $0-5$, which induces weakening of the ring $\mathrm{C}-0$ bond and the development of some double bond character in the anomeric $\mathrm{C}-0$;

(ii) attack of a hydride-like species from the copper surface from the anti-ring-0 side with inversion of configuration at the anomeric carbon;

(iii) co-adsorption of pyranose forms with relatively low reactivity.

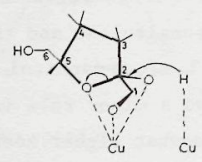

Fig. 14. Chemisorption of a D-furanose form: anti-ring-0 side H-attack.

Effect of borate addition

In the presence of borate, the copper catalyzed hydrogenation of D-fructose and isomaltulose gave enhanced yields of D-mannitol (80-90\%) and $6-0-\alpha-D-$ glucopyranosyl-D-mannitol $(75 \%)$, respectively. ${ }^{11} \mathrm{~B}$ and ${ }^{13} \mathrm{C}$ NMR spectra show that under these conditions $1: 2$ borate-sugar esters are formed, in which the sugar moiety possesses the $\beta$-furanose form ${ }^{13}$ (Fig. 15).

The borate effect can be understood on the basis of the above mentioned hydrogenation mechanism, assuming that the $1: 2$ borate-sugar esters are preferentially hydrogenated. As even small amounts of borate already affect the selectivity, relatively strong adsorption of $1: 2$ borate-sugar esters on the copper surface must occur. It may be noted that the selectivity of the other hydrogenation catalysts, e.g. ruthenium on carbon, platinum on carbon and Raney-Nickel, was not influenced by the addition of borate. Probably, these metal surfaces have less affinity towards borate-sugar esters.

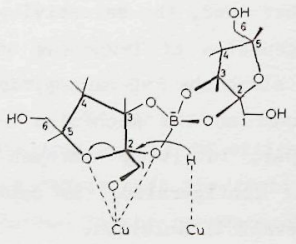

Fig. 15. Chemisorption of $1: 2$ borate- $\beta$-D-fructofuranose ester: antiring-O side H-attack.

As shown in Fig. 3, the presence of $\mathrm{CaCO}_{3}$ (as a buffering agent) partly counteracted the effect of the addition of borate, in particular at low borate concentrations. ${ }^{11} \mathrm{~B}$ and ${ }^{13} \mathrm{C}$ NMR showed that $\mathrm{CaCO}_{3}$ prohibited borate-sugar ester formation, which will be due to the formation of calcium-borate complexes, unless the borate concentration exceeded the amount of $\mathrm{CaCO}_{3}$.

Mechanism of the aldose hydrogenation over copper

D-Glucose and D-mannose are solely present as their $\alpha$ - and $\beta$-pyranose ring structures. Molecular models indicate that the adsorption of the $B$-pyranose form will be more favourable through the coordination of the anomeric, ring and C-6 oxygens with a surface copper atom (Fig. 16).

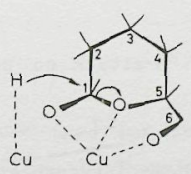

Fig. 16. Chemisorption of a B-D-pyranose form: anti-ring-o side Hattack.

Assuming comparable reactivities of the adsorbed $\alpha$ - and $\beta$-pyranose forms, the above mentioned mechanism would then predict that D-glucose 
will be preferentially converted into $(S)-1-{ }^{2} \mathrm{H}-\mathrm{D}-\mathrm{glucitol}$ upon deuterogenation with copper on silica, since the $\beta$-pyranose form is present in excess $(62 \%)$. On the other hand, the selectivity for $(S)-1-{ }^{2} \mathrm{H}-\mathrm{D}$-mannitol formation from deuterogenation of D-mannose with copper on silica is expected to be smaller, since the $\beta-D$-mannopyranose content is just $35 \%$. This expectation is based on the mechanism suggested for the ketose hydrogenation over copper, involving hydrogen attack on the anomeric carbon with inversion of configuration, as depicted in Fig. $17 \mathrm{for}$ the pyranose forms which prevail in solution.

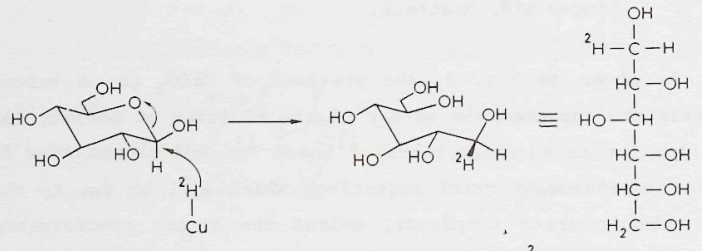

$\beta-D$ - glycopyranose

(5) $-1-^{2} H-D$ - glucitol

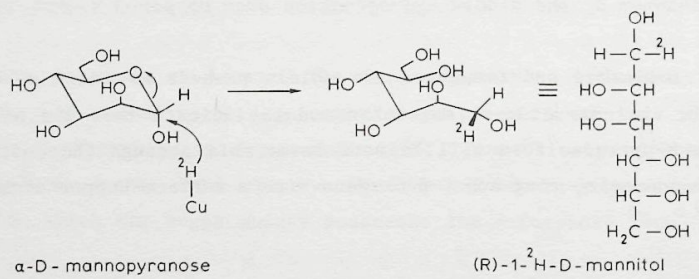

Fig. 17. Stereoselective ${ }^{2} \mathrm{H}$-attack on $\beta$-D-glucopyranose and $\alpha-D$-mannopyranose.

In order to verify these interpretations, both $\mathrm{D}-\mathrm{glucose}$ and D-mannose were deuterogenated in $\mathrm{D}_{2} \mathrm{O}$ over copper on silica at $120{ }^{\circ} \mathrm{C}$ and 50 $\mathrm{kg} / \mathrm{cm}^{2} \mathrm{D}_{2}$. The relative amounts of $(R)-$ and $(S)-1-{ }^{2} \mathrm{H}-\mathrm{D}-\mathrm{glucitol}$ and of $(R)$ - and (S) $-1-{ }^{2} \mathrm{H}-\mathrm{D}$-mannitol were determined as their respective 1,4:3,6-dianhydro derivatives. Comparison of the ${ }^{1} \mathrm{H}$ NMR spectra of these products with those of $1,4: 3,6$-dianhydro-D-glucitol and -D-mannitol from the literature 14,15 showed indeed that D-glucose yielded $80 \%$ of $(S)-1$ -
${ }^{2} \mathrm{H}-\mathrm{D}-$ glucitol, whereas D-mannose gave a $1: 1(P) /(S)$ mixture of the $1-^{2} \mathrm{H}-$ D-mannitols.

\section{Conclusions}

The results show that copper on silica may be conveniently applied as the hydrogenation catalyst in the combi-process. The selectivity for D-fructose hydrogenation in the presence of equimolar amounts af D-glucose $(0.92)$ and the selectivity for D-mannitol formation from D-fructose (0.67-0.85) are much higher than those for the other catalysts investigated. The activity of copper on silica at moderate temperatures $\left(60-80{ }^{\circ} \mathrm{C}\right)$ is, however, somewhat low. The D-fructose hydrogenation obeys Langmuir-Hinshelwood kinetics: a shift from first to zero kinetics in D-fructose is observed going from low $(<0.3 \mathrm{M})$ to high ( $>0.8 \mathrm{M})$ D-fructose concentrations. Some preferent adsorption of pyranose with respect to furanose forms on copper occurs. Adsorption takes probably place by the anomeric oxygen and the ring oxygen. The reactivity of furanose form appears to be much higher than that of a pyranose form. Combination of adsorption strength and reactivity data shows the D-fructose is preferentially hydrogenated via its furanose forms. Hydrogenation is proposed to occur by hydrogenolysis of the ionized ring for with inversion of configuration at the anomeric carbon. This mechanis further explains the enhanced D-mannitol yield from D-fructose-borate esters, the preferential ( $80 \%)(S)-1-{ }^{2} \mathrm{H}-\mathrm{D}-\mathrm{glucitol}$ formation upon deuterogenation of D-glucose, as well as the diastereoselectivity of the copper-catalyzed hydrogenation of a series of 7 ketoses.

\section{Acknowledgements}

Mr. E. Wurtz is acknowledged for technical assistance during the hydrogenation experiments, Mr. J. Theunisse for the surface determinations of the copper catalysts, and Dr. J.A. Peters for recording the MMR spectra. 


\section{References}

1. Chapter 2.

2. M. Makkee, A.P.G. Kieboom, H. van Bekkum, and J.A. Roels, J. Chem. Soc., Chem. Comm. 1980930.

3. M. Makkee, A.P.G. Kieboom, H. van Bekkum, and J.A. Roels, Abstracts of Papers, 29th IUPAC Congress, Cologne (1983) 434

4. J. Wisniak and R. Simon, Ind. Eng. Chem. Prod. Res. Dev. 18 (1979) 50 .

5. Chapter 5.

6. Eur. Pat. (1980) 6313.

7. Chapter 8.

8. J.F. Ruddlesden, A. Stewart, D.J. Thompson, and R. Whelan, Faraday Discuss. Chem. Soc. 72 (1981) 397.

9. G. de Wit, A.P.G. Kieboom, and H. van Bekkum, Rec1. Trav. Chim. Pays-Bas 98 (1979) 355.

10. A.P.G. Kieboom, J.F. de Kreuk, and H. van Bekkum, J. Catal. 20 (1971) 58 .

11. G. de Wi.t, J.J. de V1ieger, A.C. Kock-van Dalen, R. Heus, R. Laroy, A.J. van Hengstum, A.P.G. Kieboom, and H. van Bekkum, Carbohydr. Res. 91 (1981) 125.

12. A.P.G. Kieboom, Faraday Discuss. Chem. Soc. 72 (1981) 417.

13. Chapter 4.

14. F.J. Hopton and G.H.S. Thomas, Can. J. Chem. 47 (1969) 2395.

15. J.A. Peters, W.M.M.J. Bovée, and A.P.G. Kieboom, Tetrahedron, in press.
4. INTERACTION OF BORATE WITH D-MANNITOL, D-GLUCITOL, D-FRUCTOSE AND D-GLUCOSE

\section{Introduction}

In our combi-process research (the simultaneous action of the enzyme glucose isomerase and a conventional hydrogenation catalyst, applied to the preparation of D-mannitol) $)^{1-4}$ we observed that the D-mannitol yield was substantially enhanced by the addition of catalytic amounts of borate anions to the reaction formulation upon the hydrogenation of D-fructose over a supported copper catalyst. In order to get more insight in this phenomenon we have studied the interaction of borate anions with a number of hydroxy compounds and carbohydrate.

Some first principles concerning the interaction of borate anions with hydroxy compounds were established by Böeseken ${ }^{5}$ some sixty years ago in this laboratory. Borate ester formation has been used as a tool in the configurational analysis of carbohydrates and in a variety of separation and chromatographic techniques. For more than a century this class of compounds and their stability as borate esters have been studied, using several techniques (such as potentiometry and polarimetry). These techniques, however, give no direct information concerning the identity of the borate ester species involved. Henderson et al. ${ }^{6}$ were the first to use $11_{B}$ NMR for identifying borate esters of diols in water and applied their results in the carbohydrate field ${ }^{7}$. This technique provides direct information concerning the surrounding of boron. The potential of ${ }^{11} B$ NMR in the elucidation of the interaction of borate anions $\left(B^{-}\right.$) with (poly)hydroxycarboxylic acids has been quite recently demonstrated by Van Duin at al. ${ }^{8}$.

This chapter describes the combined use of $11 \mathrm{~B}$ and ${ }^{13} \mathrm{C}$ NMR spectroscopy in the structure elucidation of borate esters of some carbohydrates (L), e.g. D-mannitol, D-glucitol, D-fructose and D-glucose in aqueous solution. Special attention has been given to the influence of $\mathrm{pH}$ on the stability of the various borate esters. First of all the ${ }^{11_{B}}$ 
chemical shifts of borate esters of model 1,2-, 1,3- and 1,4-diols have been determined in order to be able to distinguish between $5-, 6$ - and 7-membered ring systems in both mono-esters $\left(\mathrm{BL}^{-}\right.$) and di-esters ( $\mathrm{BL}_{2}^{-}$) by 7 -membered ring systems in both mono-esters stabilities. The $11_{\mathrm{B}}$ $11 \mathrm{~B} N M R$ and to estimate the respective borate an appropriate choice of the NMR results thus obtained further allowed an appropriate choice of the ester formulation ( $\mathrm{pH}$, borate/polyol ratio) to be studid by i.e. where only one or two borate ester species occur predominat. From ${ }^{13} \mathrm{C}$ MR the esterified hydroxyls of the polyol were establist

\section{Experimental}

$11_{B}$ NMR and ${ }^{13} \mathrm{C}$ NMR spectra were recorded at $25{ }^{\circ} \mathrm{C}$ with a Nicolet $11 B$ NMR and ${ }^{13} \mathrm{C}$ NMR spectra were recorded at $25{ }^{\circ} \mathrm{C}$ with a Nicoter NT-200 WB spectrometer at $64.19 \mathrm{MHz}$ with $0.1 \mathrm{M}$ boric acid as the external reference and a Varian CFT 20 spectrometer at $20.12 \mathrm{MHz}$ with dioxane in the $C_{B}=0.1 \mathrm{M}$ for all the ${ }^{11} \mathrm{~B}$ NMR spectra and the total polyol concentration $C_{L}=0.1 \mathrm{M}$ for a11 the ${ }^{13} \mathrm{C}$ NMR spectra. The samples were prepared by dissolution of the appropriate amounts of boric acid and in $\mathrm{D}_{2} \mathrm{O}$. The $\mathrm{pH}$ was adjusted with $40 \% \mathrm{NaOD}$ in $\mathrm{D}_{2} \mathrm{O}$ (Merck) and the pach sample was $5 \mathrm{~m} 1$. Isomaltulose was a gift of südtotal volume of each sample was 5 mill other chemi-

deutsche zucker A.G. which is gratefully acknowledged available.

\section{Results and discussion}

Interaction of borate anions with diols

The interconversion of boric acid and borate anions, and the interthe following equilibria:

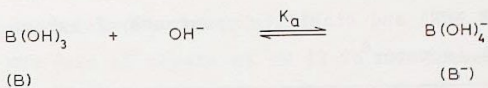

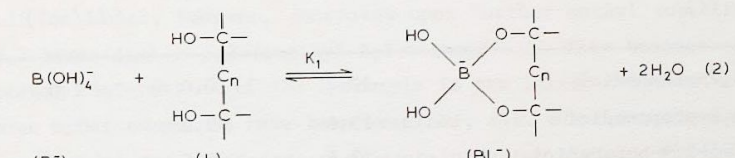

$\left(B^{-}\right)$

$\left(\mathrm{BL}^{-}\right)$

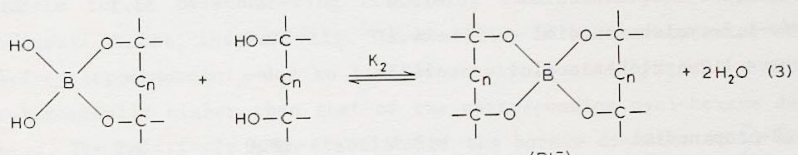

$\left(\mathrm{BL}^{-}\right)$

$\left(\mathrm{BL}_{2}^{-}\right)$

The association constants for these equilibria are defined as:

$$
\begin{aligned}
& \mathrm{K}_{\mathrm{a}}=\left[\mathrm{B}^{-}\right] /\left([\mathrm{B}] *\left[\mathrm{OH}^{-}\right]\right) \\
& \mathrm{K}_{1}=\left[\mathrm{BL}^{-}\right] /\left(\left[\mathrm{B}^{-}\right] *[\mathrm{~L}]\right) \\
& \mathrm{K}_{2}=\left[\mathrm{BL}_{2}^{-}\right] /\left(\left[\mathrm{BL}^{-}\right] *[\mathrm{~L}]\right)
\end{aligned}
$$

Over the $\mathrm{pH}$ range of 3-14 there is only one signal observed for the boric acid/borate equilibrium. The change in chemical shift over this $\mathrm{pH}$ range (Fig. 1) may be ascribed to the variation in the relative concentrations of boric acid and borate species (eq. (1)) which interconversion is fast on the $11_{B}$ MMR time scale.

The NMR signals at $\delta=0 \mathrm{ppm}$ and $\delta=-17.6 \mathrm{ppm}$ correspond to boric acid and borate, respectively. The formation of diol borate esters and

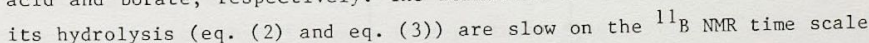
at $25{ }^{\circ} \mathrm{C}$, i.e. separate signals for the free and complexed boron species are observed.

Table I shows ${ }^{11}$ B chemical shift data of borate esters of a series of selected diols. By varying the relative concentration of diol and borate it could be ascertained which signal belonged to the mono-ester $\left(\mathrm{BL}^{-}\right)$, which to the di-ester $\left(\mathrm{BL}_{2}^{-}\right)$and which of these signals corresponds to a 5-, 6- or 7-membered ring borate ester. The boron mass 
TABLE I

Chemical shifts ( ${ }^{11}$ B NMR) and stability constants of esters of dihydroxy compounds and borate in water ${ }^{2}$

\begin{tabular}{|c|c|c|c|c|}
\hline $\begin{array}{l}\text { Compound } \\
\text { (L) }\end{array}$ & $\delta\left(\mathrm{BL}^{-}\right)^{\mathrm{b}}$ & $\hat{o}\left(\mathrm{BL}_{2}^{-}\right)^{\mathrm{b}}$ & $\begin{array}{c}\mathrm{K}_{1} \\
(1 / \mathrm{mo} 1)\end{array}$ & $\begin{array}{c}\mathrm{K}_{2} \\
(1 / \mathrm{mol})\end{array}$ \\
\hline 1,2-ethanediol & -13.7 & -10.0 & 1.0 & -- \\
\hline 1,2-propanediol & -13.6 & -9.9 & 1.4 & 0.4 \\
\hline$( \pm)-2,3$-butanediol & -13.6 & -9.6 & 8.7 & 2.4 \\
\hline 2,3-dimethy-2,3-butanediol & -14.8 & - & 3.6 & -- \\
\hline cis-1,2-cyclopentanediol & -13.6 & -9.4 & 33.3 & 78.1 \\
\hline eis-1,2-cyclohexanediol & -14.2 & -10.7 & 1.2 & -- \\
\hline trans-1,2-cyclohexanediol & $-14 \cdot 3$ & -- & -- & -- \\
\hline 1,3-propanediol & -18.4 & -19.0 & 0.9 & -- \\
\hline 1,3-butanediol & -18.2 & -18.9 & 1.9 & -- \\
\hline 1,4-butanediol & -16.7 & -- & -- & -- \\
\hline
\end{tabular}

a $0.1 \mathrm{M}$ boric acid, $0.1 \mathrm{M}$ dihydroxy compound, $\mathrm{pH}=12.0,25^{\circ} \mathrm{C},\left[\mathrm{B}^{-}\right] /[\mathrm{B}]$ $=8.5 * 10^{2}$.

b In ppm with respect to $0.1 \mathrm{M}$ boric acid as the external reference.

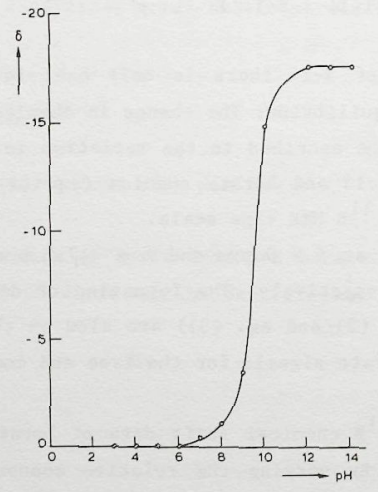

Fig. 1. ${ }^{11} \mathrm{~B}$ NMR chemical shift of boric acid as function of $\mathrm{pH}(0.1 \mathrm{M}$ $\left.\mathrm{H}_{3} \mathrm{BO}_{3}, \mathrm{D}_{2} \mathrm{O}, 25{ }^{\circ} \mathrm{C}\right)$. balance together with the integrated $11_{B}$ NMR spectra yielded the borate ester stabilities $\left(K_{1}\right.$ and $K_{2}$ ).

${ }^{11} \mathrm{~B}$ NMR data of borate at $\mathrm{pH} 12$ in the presence of equimolar amounts of acyclic 1,2-diols showed that methyl substitution at the hydroxyl carbons first enhances $K_{1}(( \pm)-2,3$-butanediol $>1,2$-propanediol $>1,2-$ ethanediol), which, however, decreases upon further methyl substitution $(( \pm)$-2,3-butanediol > 2,3-dimethyl-2,3-butanediol). This because of the anti-planar conformation of the hydroxyls in the latter compound.

Three other compounds have been examined, i.e. cis-1,2-cyclopentanediol, as a model for a furanose ring containing two vicinal cis-hydroxyl groups and cis-1,2-cyclohexanediol and trans-1,2-cyclohexanediol as models for a pyranose ring containing two vicinal ax/eq and eq/eq hydroxyl groups, respectively. The stability of the borate ester of cis1,2-cyclopentanediol, due to its favourably located hydroxyl groups, is substantially higher than that of the corresponding cyclohexane derivative. The relatively high stability of the borate di-ester (BL ${ }_{2}^{-}$) of cis1,2 -cyclopentanediol is noteworthy. The borate ester formation as a function of $\mathrm{pH}$ is given in Fig. 2 for 1,2-ethanediol, cis-1,2-cyclohexanediol and cis-1,2-cyclopentanediol. The results are consistent with the 'charge rule' developed by Van Duin et at. ${ }^{8}$, i.e. an increase of borate ester formation at increasing $\mathrm{pH}$. The slight decrease in concen-

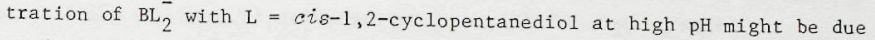
to ionization of one of the two hydroxyl groups.

The stability of borate esters of acyclic 1,3-diols lie in the same range as those of borate esters of acyclic 1,2-diols, whereas the formation of borate esters of acyclic 1,4-diols is negligible.

In conclusion $11_{B}$ MMR spectroscopy provides direct information of the surroundings of the boron species (due to ${ }^{11} \mathrm{~B}$ chemical shift differences) and offers the possibility to calculate the borate ester stabilities. Two vicinal cis-hydroxyl groups in a furanose ring possess a much more favourable geometry for the formation of borate esters than two vicinal cis-hydroxyl groups in a pyranose ring. 

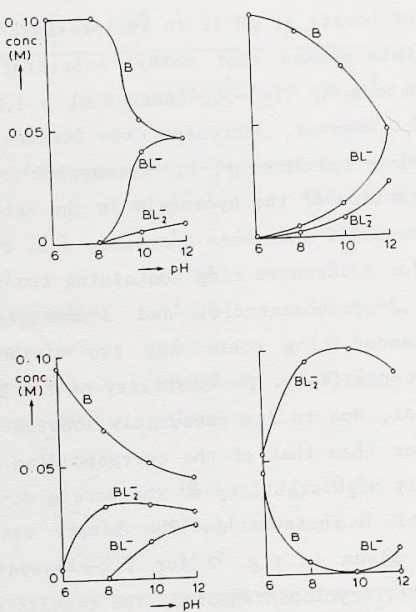

Fig. 2. For to function of $\mathrm{pH}(0.1$ $\left.\mathrm{H}_{3} \mathrm{BO}_{3}, \mathrm{D}_{2} \mathrm{O}, 25^{\circ} \mathrm{C}\right)$; A 1,2-ethanediol $(1.0 \mathrm{M}), \mathrm{B}$ cis-1,2-cyclohexanediol $(1.0 \mathrm{M}), \mathrm{C}$ eis-1,2-cyclopentanediol $(0.1 \mathrm{M})$, D cis1,2-cyclopentanediol ( $1.0 \mathrm{M})$.

Interaction of borate anions with D-mannitol

The ester formation between $\mathrm{D}$-mannitol and borate has been studied $11 \mathrm{~B}$ NMR at $\mathrm{pH}=6-12$ and different D-mannitol/borate ratios (Fig. 3). In accordance with the results of the model dihydroxy compounds, the

In accordance with the resunt of borate esterified increases upon increasing $\mathrm{pH}$.

At high D-mannitol/borate ratios (Fig. 3; L > $0.1 \mathrm{M}$ ) bis(D-mannitol) borate $\left(\mathrm{BL}_{2}^{-}\right)$occurs predominantly. It has to be noted that, in parti( cular at low D-mannitol/borate ratios of the type $\mathrm{B}_{2} \mathrm{~L}^{2-}$ and $\mathrm{B}_{3} \mathrm{~L}^{3-}$. On the analogy of the phenylboronate esters of D-mannitol, the following species are expected to be present in addition to $\mathrm{BL}^{-}$, as illustrated in Fig. 4.

Under the hydrogenation conditions applied (sugar/borate ratio 160 , $\mathrm{pH}$ 7) the two major D-mannitol species present are free D-mannitol and
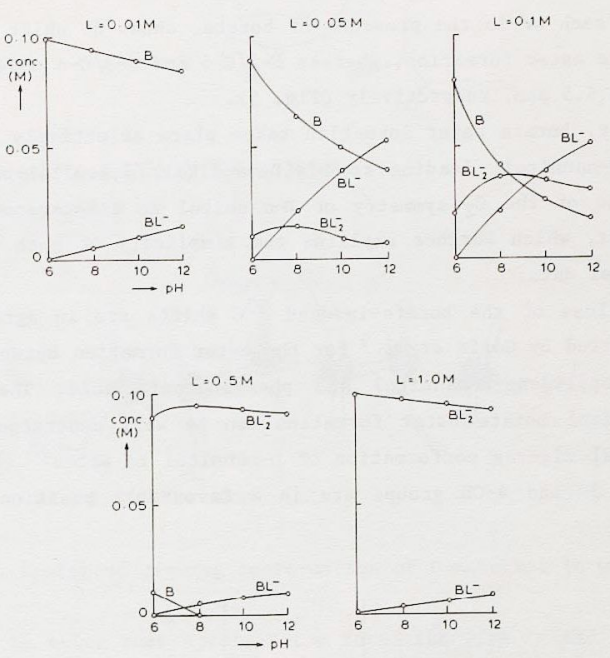

Fig. 3. D-Mannitol (L) borate ester formation as function of $\mathrm{pH}$ and [L] $\left(0.1 \mathrm{M} \mathrm{H}_{3} \mathrm{BO}_{3}, \mathrm{D}_{2} \mathrm{O}, 25^{\circ} \mathrm{C}\right)$.

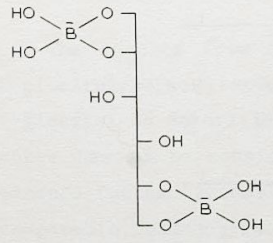

$\mathrm{B}_{2} \mathrm{~L}^{2}$

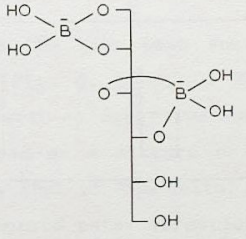

$\mathrm{B}_{2} \mathrm{~L}^{2}$

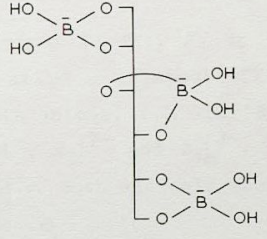

$B_{3} L^{3-}$
Fig. 4. Structural possibilities of D-mannitol di- and tri-borate esters.

bis(D-mannitol) borate $\left(\mathrm{BL}_{2}^{-}\right)$(Fig. $\left.3 ; \mathrm{L}=1.0 \mathrm{M}\right)$. Although there are many different structural possibilities for $\mathrm{BL}_{2}^{-}$, both $11_{\mathrm{B}}$ NMR (one signal at $\delta=-9.50$ ) and ${ }^{13} \mathrm{C}$ NMR (only two new signals at $\delta=74.0$ and 75.8) point to the formation of one structural isomer with high symme- 
try. Comparison of the ${ }^{13} \mathrm{C}$ NMR spectra of $\mathrm{D}$-mannitol and $2-{ }^{2} \mathrm{H}-\mathrm{D}$-mannitol, as such or in the presence of borate, shows no shift for $\mathrm{C}-1 / \mathrm{C}-6$ upon borate ester formation, whereas $\mathrm{C}-2 / \mathrm{C}-5$ and $\mathrm{C}-3 / \mathrm{C}-4$ undergo a shift of 2.1 and $5.5 \mathrm{ppm}$, respectively (Fig. 5).

Clearly, borate ester formation takes place selectively with $3-$ and 4-OH of D-mannitol, leading to bis(D-mannitol) 3,4;3',4'-borate (Fig. 6). Because of the $C_{2}$ symmetry of D-mannitol no diastereomers of this ester exist, which further explains the simplicity of both ${ }^{11_{B}}$ and ${ }^{13} \mathrm{C}$ NMR spectral data.

The values of the borate-induced ${ }^{13} \mathrm{C}$ shifts are in agreement with those reported by Gorin et al. ${ }^{9}$ for the ester formation between 1,2;5,6di-O-isopropylidene-D-mannitol and phenylboronic acid. The selective 3,4-D-mannitol borate ester formation can be well understood from the preferential zig-zag conformation of D-mannitol in water ${ }^{10}$ (Fig. 7), in which the 3- and - 4-OH groups are in a favourable position for ester formation.
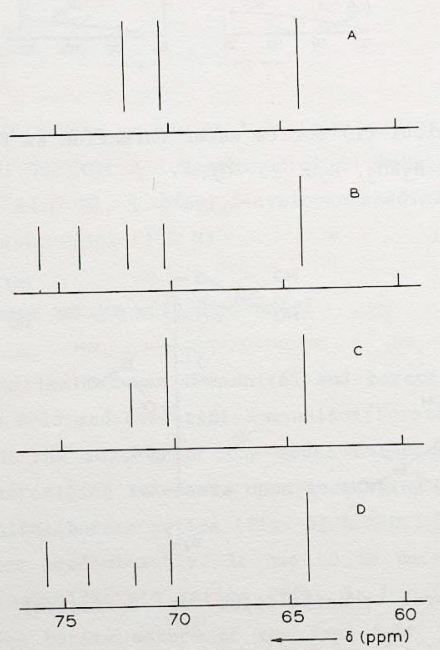

Fig. $5 .{ }^{13} \mathrm{C}$ MMR spectra of $0.1 \mathrm{M}$ D-mannitol without (A) and in the presence (B) of $0.025 \mathrm{M} \mathrm{H}_{3} \mathrm{BO}_{3}\left(\mathrm{D}_{2} \mathrm{O}, \mathrm{pH} \sim 6,25^{\circ} \mathrm{C}\right)$; idem for $2-{ }^{2} \mathrm{H}-\mathrm{D}$-mannitol ( $C$ and $\mathrm{D}$ ).

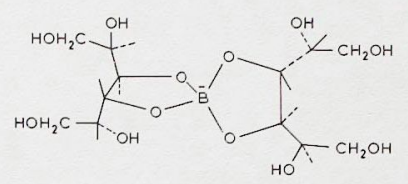

Fig. 6. Bis(D-mannitol) 3,4;3',4'-borate.

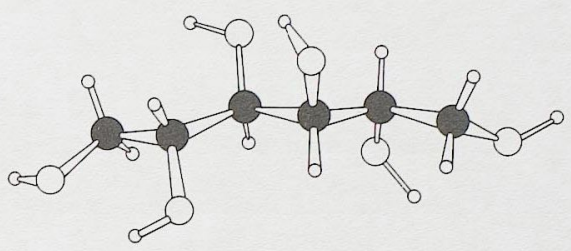

Fig. 7. Preferred zig-zag conformation of D-mannitol in water.

It may be noted that borate ester formation with 1- and 2-OH (or 5- and $6-\mathrm{OH})$ is less favourable because of the greater freedom of rotation of the hydroxy methyl group, resulting in an unfavourable change in entropy upon esterification.

Interaction of borate anions with D-glucitol

The results from $11_{B}$ NMR have been summarized in Fig. 8. At low D-glucitol/borate ratio (Fig. $8 ; \mathrm{L}=0.01 \mathrm{M}$ ) at $\mathrm{pH}=12$ about $90 \%$ of D-glucitol is esterified with at least two borate anions, i.e. the ' $\mathrm{BL}^{-}$', curve has to be considered as a mixture of $\mathrm{BL}^{-}, \mathrm{B}_{2} \mathrm{~L}^{2-}$ and $\mathrm{B}_{3} \mathrm{~L}^{3-}$. The picture further resembles that of D-mannitol, i.e. both alditols show a comparable tendency for borate ester formation.

From ${ }^{11}$ B NMR (Fig. 8; $\mathrm{L}=1.0 \mathrm{M}$; one signal at $\delta=-9.50$ ) it follows that $\mathrm{BL}_{2}^{-}$is a spirocyclic 5-membered ring ester. In contrast to $\mathrm{D}$-mannitol, however, ${ }^{13} \mathrm{C}$ NMR of a solution containing predominant $1 \mathrm{y} \mathrm{BL}_{2}^{-}$and D-glucitol shows a great number of signals (around $\delta \approx 64,72$ and 74) in addition to the six signals of 'free' D-glucitol (Fig. 9). 

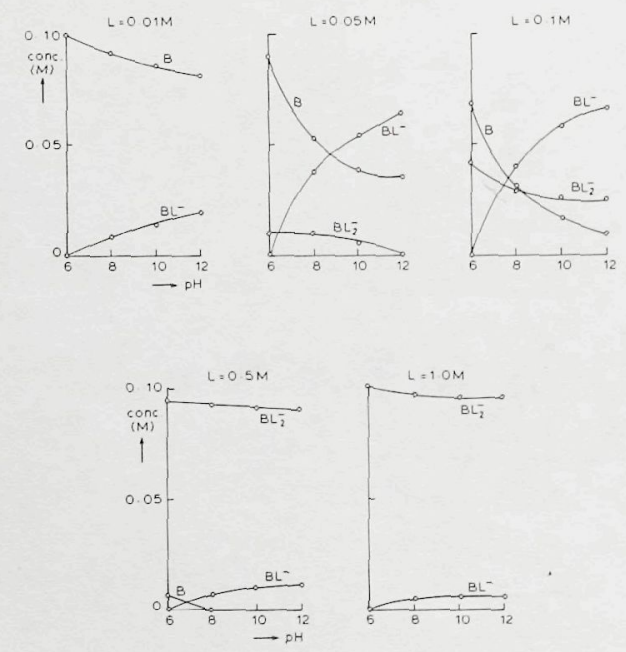

Fig. 8. D-Glucitol (L) borate ester formation as function of $\mathrm{pH}$ and [L] $\left(0.1 \mathrm{M} \mathrm{H}_{3} \mathrm{BO}_{3}, \mathrm{D}_{2} \mathrm{O}, 25^{\circ} \mathrm{C}\right)$.

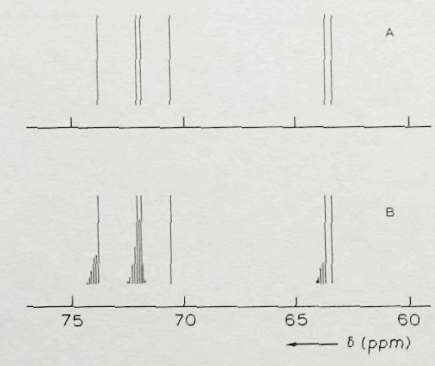

Fig. $9 .{ }^{13} \mathrm{C}$ MMR spectra of $0.1 \mathrm{M}$ D-glucitol without (A) and in the presence (B) of $0.025 \mathrm{M} \mathrm{H}_{3} \mathrm{BO}_{3}\left(\mathrm{D}_{2} \mathrm{O}, \mathrm{pH} \sim 6,25{ }^{\circ} \mathrm{C}\right)$.
At least four different $\mathrm{BL}_{2}^{\sim}$ species are present. D-Glucitol possesses in water a zig-zag structure ${ }^{10}$ (Fig. 10) in which the 2-, 3- and 4-OH groups are all in a favourable position for borate ester formation.

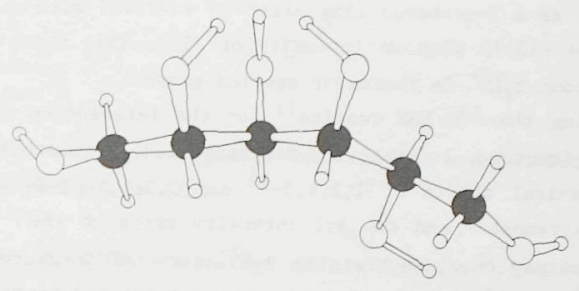

Fig. 10. Preferred zig-zag conformation of D-glucitol in water.

Therefore, the following six bis(D-glucitol) borates (BL ${ }_{2}^{-}$) are expected to occur:

bis(D-glucitol) (R)-2,3;2', 3'-borate (Fig. 11)

bis(D-glucitol) (S)-2,3;2', $3^{\prime}$-borate (Fig. 11)

bis(D-glucitol) ( $R)-3,4 ; 3^{\prime}, 4^{\prime}$-borate

bis(D-glucitol) $(S)-3,4^{\prime} ; 3^{\prime}, 4^{\prime}$-borate

bis(D-glucitol) $(R)-2,3 ; 3^{\prime}, 4^{\prime}$-borate

bis(D-glucito1) $(S)-2,3 ; 3^{\prime}, 4^{\prime}$-borate

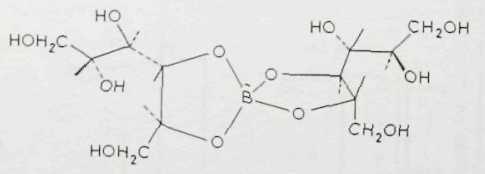

(R)

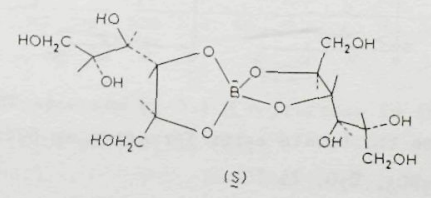

Fig. 11. Bis(D-glucitol (R)- and $(S)-2,3 ; 2^{\prime}, 3^{\prime}$-borate. 
Interaction of borate anions with D-fructose

At low concentration of D-fructose (Fig. $12 ; \mathrm{L}=0.01 \mathrm{M}$ ) at $\mathrm{pH}=12$ the $11_{B}$ NMR results show that $90 \%$ of $D$-fructose is esterified with two borates as a 5-membered ring ester ( $\delta=-13.01$ with an intensity of $25 \%$ and $\delta=-13.72$ with an intensity of $75 \%$ ). This means that under these conditions $\mathrm{B}_{2} \mathrm{~L}^{2-}$ is the major species present.

Using the ${ }^{13} \mathrm{C}$ NMR results ${ }^{11}$ for the interaction of phenylboronates with D-fructose, 1-O-methyl-D-fructose and 2-O-methyl-D-fructose, the ${ }^{13} \mathrm{C}$ chemical shifts of 1,$2 ; 4,5-12$ and 2,$3 ; 4,5-d i-0$-isopropylidene- $\beta-D-$ fructopyranose ${ }^{13}$ and the $3: 1$ intensity ratio of the $11_{B}$ signals in our case, we may conclude that the $\mathrm{B}_{2} \mathrm{~L}^{2-}$ ester of $\mathrm{D}$-fructose is an equilibrium of two esters: $\beta-D$-fructopyranose 1,$2 ; 4,5$-diborate and $\beta-D$-fructopyranose 2,3;4,5-diborate (Fig. 13).
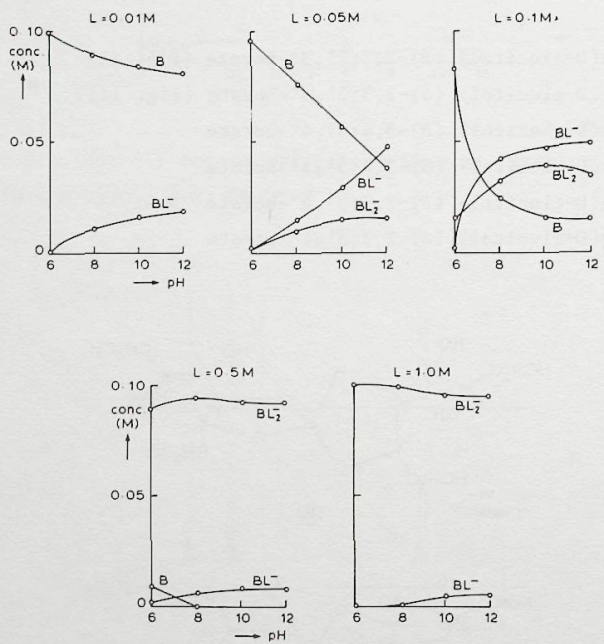

Fig. 12. D-Fructose (L) borate ester formation as function of $\mathrm{pH}$ and [L] $\left(0.1 \mathrm{M} \mathrm{H}_{3} \mathrm{BO}_{3}, \mathrm{D}_{2} \mathrm{O}, 25^{\circ} \mathrm{C}\right)$
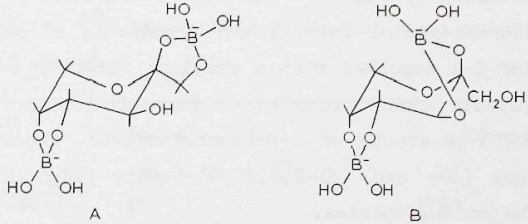

Fig. 13. $\beta$-D-Fructopyranose 1,2;4,5-diborate (A) and $\beta$-D-fructopyranose 2,$3 ; 4,5$-diborate $(B)$.

At higher D-fructose/borate ratios (Fig. 12; L $>0.1 \mathrm{M}$ ) the picture further resembles that of $D$-mannitol and D-glucitol. ${ }^{11}$ B NMR (one signal at $\delta=-9.50$ ) shows that $\mathrm{BL}_{2}^{-}$is a spirocyclic 5 -membered ring borate ester. ${ }^{13} \mathrm{C}$ NMR reveals six new signals ( 3 doublets, 1 triplet and 2 singulets) in addition to the 18 signals of D-fructose (Fig. 14).

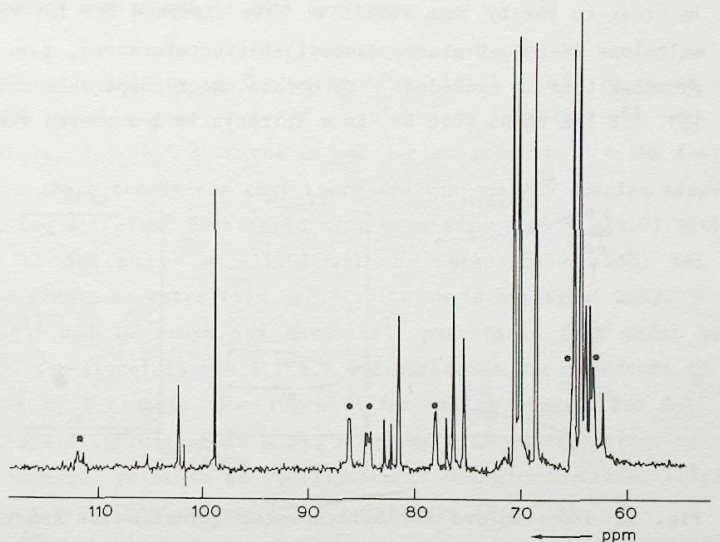

Fig. $14 .{ }^{13} \mathrm{C}$ NMR spectrum of $0.1 \mathrm{M} \mathrm{D}$-fructose in the presence of $0.017 \mathrm{M}$ $\mathrm{H}_{3} \mathrm{BO}_{3}\left(\mathrm{D}_{2} \mathrm{O}, \mathrm{pH} \sim 6,25^{\circ} \mathrm{C}\right)$.

D-Fructose is present in 4 different forms in water, i.e. B-D-fructopyranose, $\alpha-$ and $\beta-D-f$ ructofuranose and the keto form, which could 
interact with borate. Taking into account the relatively high stability interact we an on $1 y$ one doublet of cis-1,2-cyclopentanediol borate, the appearance of only one doth at low field for $\mathrm{C}-2$ together with a chemical shift of $8-9$ ppa for both C-2 and $C-3$ reveals that borate ester formation occurs predominanty

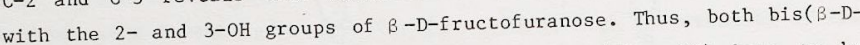
Er considered as major $\mathrm{BL}_{2}^{-}$species.

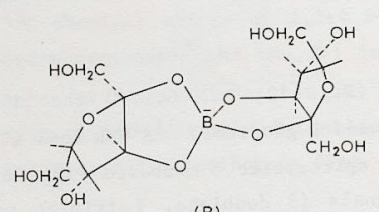

(R)

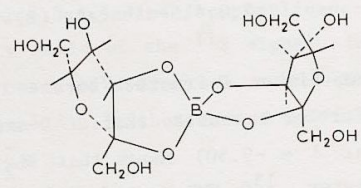

(s)
Fig. 15. Bis( $\beta$-D-fructof uranose $)(R)$ - and $(S)-2,3^{\prime} ; 2^{\prime} 3^{\prime}$-borate.

In order to verify this result we have examined the interaction of isoIn order $(6-0-(\alpha-D-g 1$ copyranosy1)-D-fructofuranose, i.e. the D-fructopyranose form is excluded) with borate under comparable conditions (Fig. 16). ${ }^{11} 1_{B}$ NMR shows that $\mathrm{BL}_{2}^{-}$is a spirocyclic 5 -membered ring ester.
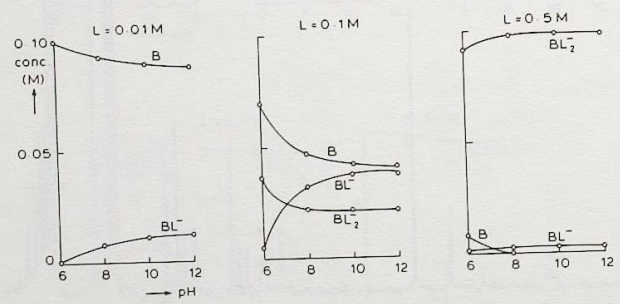

Fig. 16. Isomaltulose ( $\mathrm{L}$ ) borate ester formation as function of $\mathrm{pH}$ an [L] $\left(0.1 \mathrm{M} \mathrm{H}_{3} \mathrm{BO}_{3}, \mathrm{D}_{2} \mathrm{O}, 25^{\circ} \mathrm{C}\right)$.

With ${ }^{13} \mathrm{C} \mathrm{MMR}$, the addition of borate to a solution of isomaltulose shows the same phenomena as described above for D-fructose. In addition, the observed borate-induced shifts for isomaltulose and D-fructose agree quite well (Table II), so that indeed the 2- and 3-OH groups of the B-Dfructofuranose moiety are involved in borate ester formation.
TABLE II

Chemical shifts ${ }^{13} \mathrm{C}$ NMR of $D$-fructose and isomaltulose and of the borate diesters in water ${ }^{a}$

\begin{tabular}{|c|c|c|c|c|c|c|}
\hline & \multicolumn{3}{|c|}{ D-Fructose } & \multicolumn{3}{|c|}{ Isomaltulose } \\
\hline & $\delta$ & $\delta$ & $\Delta \delta$ & $\delta$ & $\delta$ & $\Delta \delta$ \\
\hline & $\beta-F^{11}$ & $\mathrm{BL}_{2}^{-}$ & & $B-\mathrm{FF}^{14}$ & $\mathrm{BL}_{2}^{-}$ & \\
\hline$C-1$ & 63.7 & 65.2 & 1.5 & 63.7 & 65.1 & 1.4 \\
\hline$C-2$ & 102.4 & 111.6 & 9.2 & 102.6 & 111.5 & 8.9 \\
\hline$C-3$ & 76.4 & 84.4 & 8.0 & 76.3 & 84.4 & 8.1 \\
\hline$C-4$ & 75.4 & 78.1 & 2.7 & 75.5 & 78.4 & 2.9 \\
\hline$C-5$ & 81.6 & 86.2 & 4.6 & 81.9 & 85.7 & 3.8 \\
\hline$C-6$ & 63.3 & 63.0 & -0.3 & 68.7 & 68.4 & -0.3 \\
\hline
\end{tabular}

a $0.1 \mathrm{M}$ carbohydrate, $0.015 \mathrm{M}$ boric acid, $\mathrm{pH}=6.0,25^{\circ} \mathrm{C}$.

b In ppm using $0.1 \mathrm{M}$ dioxane as the external reference.

Interaction of borate anions with D-glucose

At low concentration of D-glucose (Fig. 17; L $=0.01 \mathrm{M}$ ) at $\mathrm{pH}=12$ the $11_{B}$ NMR results show that $90 \%$ of $D$-glucose is esterified with two borate anions, i.e. $\mathrm{B}_{2} \mathrm{~L}^{2-}$ is the major species present. ${ }^{11} \mathrm{~B}$ NMR further shows under these conditions that there are various $\mathrm{BL}^{-}$species present, including two different 5-membered ring mono-esters $(\delta=-13.03$ with an intensity of $50 \%$ and $\delta=-15.08$ with an intensity of $25 \%$ ) and one 6 -membered ring mono-ester $(\delta=-17.92$ with an intensity of $25 \%)$.

De Wit ${ }^{11}$ and De Bruyn and Anteunis ${ }^{15}$ postulated that under these conditions -D-glucofuranose 1,$2 ; 3,5,6$-diborate is the structure of the $\mathrm{B}_{2} \mathrm{~L}^{2-}$ ester of $\mathrm{D}-\mathrm{g}$ lucose. The three different ${ }^{11} \mathrm{~B}$ signals for $\mathrm{B}_{2} \mathrm{~L}^{2-}$ in the ratio $2: 1: 1$ (belonging to a 5-, a 5- and a 6-membered ring, respectively), however, point to an equilibrium of $\alpha$-D-glucofuranose 1,$2 ; 3,5-$ diborate and $\alpha-D-g 1$ ucofuranose 1,2;5,6-diborate (Fig. 18).

De Wit ${ }^{11}$ also found that the borate ester stability for the $\mathrm{B}_{2} \mathrm{~L}^{2-}$ species is higher than that of the $\mathrm{BL}^{-}$species. The fact that $\mathrm{D}-\mathrm{glucose}$ is solely present in its pyranose forms together with the observed 'strong interaction' of boron species with cis-1,2-cyclopentanediol mean 

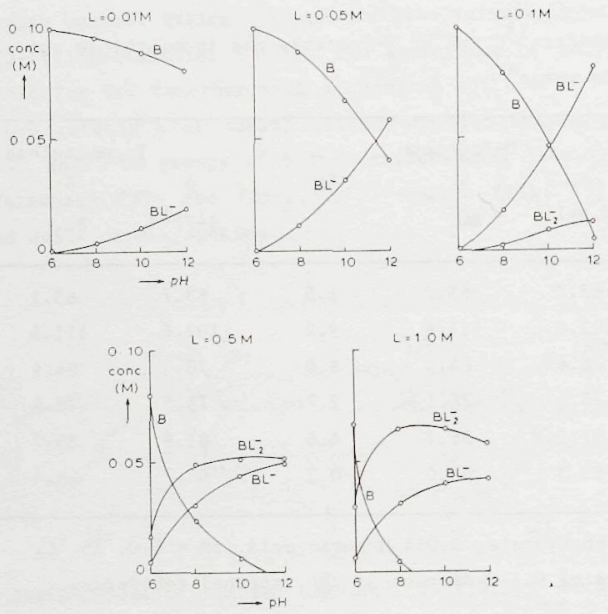

Fig. 17. D-Glucose (L) borate ester formation as function of $\mathrm{pH}$ and [L] $\left(0.1 \mathrm{M} \mathrm{H}_{3} \mathrm{BO}_{3}, \mathrm{D}_{2} \mathrm{O}, 25^{\circ} \mathrm{C}\right)$.
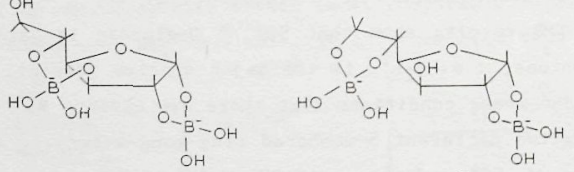
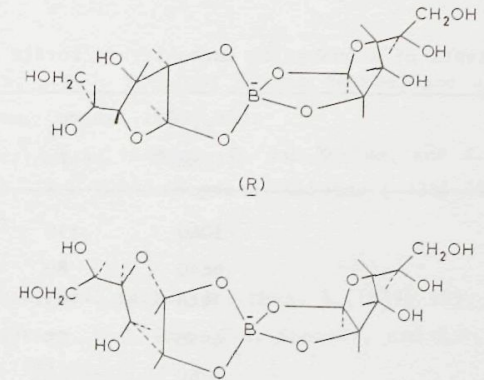

(S)

Fig. 19. Bis( $\alpha-D-g 1$ ucofuranose $)(R)-$ and $(S)-1,2 ; 1^{\prime}, 2^{\prime}$-borate.

Effect of borate in the D-fructose hydrogenation

The selectivity for the copper-catalyzed hydrogenation of $D$-f ructose towards D-mannitol in the presence of borate is initially high (0.90$0.95)$, but decreases gradually towards 0.67 at higher conversions, i.e. the selectivity for D-mannitol formation in the absence of borate anions. The drop in selectivity is caused by the fact that the overall borate ester stabilities $\left(K_{1} * K_{2}\right)$ of D-mannitol, D-glucitol and D-fructose are more or less the same (Table III) and, consequentIy, the amount of bis(D-fructose) borate will progressively diminish upon increasing conversion.
Fig. 18. $\alpha-D$-Glucofuranose 1,$2 ; 3,5$-diborate (A) and $\alpha$-D-glucofuranose 1,2;5,6-diborate (B).

that D-glucose has to transform into its furanose forms of which the $\alpha$ anomer is by far more suitable for esterification with two boron species.

At higher D-glucose/borate ratios (Fig. 17; L >0.5 M) at neutral $\mathrm{pH}$ $11_{B}$ NMR (one signal at $\delta=-8.72$ ) points to the formation of a spirocyclic 5-membered ring $\mathrm{BL}_{2}^{-}$ester. Unfortunately, due to the low stability constant, ${ }^{13} \mathrm{C}$ MMR reveals no clear new signals in addition to the 12 signals of D-glucose. Taking into account the results for D-fructose and cis-1,2-cyclopentanediol, we propose that the following two bis(Dglucose) borates occur predominantly: bis( $\alpha-D-g 1$ cofuranose $)(R)-$ and $(S)-1,2 ; 1^{\prime}, 2^{\prime}$-borate (Fig. 19). 
TABLE III

Stability constants of a number of carbohydrate/borate esters in water

\begin{tabular}{|c|c|c|c|}
\hline Carbohydrate & $\begin{array}{c}\mathrm{K}_{1} \\
(1 / \mathrm{mol})\end{array}$ & $\begin{array}{c}\mathrm{K}_{2} \\
(1 / \mathrm{mol})\end{array}$ & $\begin{array}{c}\mathrm{K}_{1} * \mathrm{~K}_{2} \\
\left(1^{2} / \mathrm{mol}^{2}\right)\end{array}$ \\
\hline D-Mannitol & 1060 & 150 & $15.910^{4}$ \\
\hline D-Glucitol & 6840 & 80 & $54.710^{4}$ \\
\hline D-Glucose & 940 & 3 & $0.310^{4}$ \\
\hline D-Fructose & 4950 & 75 & $37.110^{4}$ \\
\hline Isomaltulose & 3660 & 160 & $58.610^{4}$ \\
\hline $6-O-\alpha-D-G 1$ ucopyranosy1-D-mannito1 & 1120 & 310 & $34.710^{4}$ \\
\hline 6-O- $\alpha-D-G 1$ ucopyranosyl-D-glucitol & 1300 & 310 & $40.310^{4}$ \\
\hline
\end{tabular}

a $0.1 \mathrm{M}$ boric acid, $0.5 \mathrm{M}$ carbohydrate, $\mathrm{pH}=7.0,25{ }^{\circ} \mathrm{C},\left[\mathrm{B}^{-}\right] /[\mathrm{B}]=8.5$ $\div 10^{-3}$.

\section{Conclusions}

Combination of $11_{B}$ and ${ }^{13} C$ NMR is a valuable tool for the elucidation of ester formation between borate and polyhydroxy compounds. Both the structures and stability constants of the borate esters of D-mannitol, D-glucitol, D-fructose and D-glucose have been determined in this way. The overall stability constant for borate di-esters of D-mannitol, D-glucitol and D-fructose is about two orders of magnitude higher than that of D-glucose. D-Mannitol leads to one borate di-ester, D-glucose as we11 as D-fructose to two diastereomeric borate di-esters and D-glucitol to up to six different borate di-esters. The presence of a moiety containing two vicinal secondary hydroxyl groups in a 'cis-like' arrangement is most favourable for borate ester formation.

\section{Acknowledgements}

Dr. J.A. Peters and Ir. A. Sinnema are acknowledged for recording the ${ }^{11_{B}}$ NMR spectra.

\section{References}

1. M. Makkee, A.P.G. Kieboom, H. van Bekkum, and J.A. Roels, J. Chem. Soc., Chem. Commun. 1980, 930.

2. M. Makkee, A.P.G. Kieboom, H. van Bekkum, and J.A. Roels, Abstracts of Papers, 29th IUPAC Congress, Cologne (1983) 434.

3. Chapter 3.

4. Chapter 7.

5. J. Böeseken, Adv. Carbohydr. Chem. 4 (1949) 189.

6. W.G. Henderson, M.J. How, G.R. Kennedy, and E.F. Mooney, Carbohydr. Res. 28 (1973) 1.

7. G.R. Kennedy and M.J. How, Carbohydr. Res. 28 (1973) 13.

8. M. van Duin, J.A. Peters, A.P.G. Kieboom, and H. van Bekkum, Tetrahedron, in the press.

9. P.A.J. Gorin and M. Mazurek, Can. J. Chem. 51 (1973) 3277.

10. A.P.G. Kieboom, T. Spoormaker, A. Sinnema, J.M. van der Toorn, and H. van Bekkum, Recl. Trav. Chim. Pays-Bas 94 (1975) 53.

11. G. de Wit (1979), Ph.D. Thesis, Gedrag van glucose, fructose en verwante suikers in alkalisch milieu (Delft University of Technology, The Netherlands)

12. E.J. Prisbe, J. Smejkal, J.P.H. Verheyden, and J.G. Moffatt, J. Org. Chem. 41 (1976) 1836.

13. G. de Wit, A.P.G. Kieboom, and H. van Bekkum, unpublished results.

14. H.C. Jarrell, T.F. Conway, P. Moyne, and I.C.P. Smith, Carbohydr. Res. 76 (1979) 45.

15. A. de Bruyn and M. Anteunis, Acta Ciencia Indica 2 (1976) 1 and references cited therein. 
The reaction conditions of the simultaneous enzynatic interconversion D-glucose $\rightleftharpoons$ D-fructose and the preferential hydrogenation of $D-f r u c t o s e$, as a novel dual catalytic approach towards the preparation of D-mannitol ${ }^{1,2}$, will be largely determined by the biocatalyst. In general, glucose isomerase from various sources requires for its catalytic action: (i) a divalent cation such as $\mathrm{Mg}$ (II), $\mathrm{Co}(\mathrm{II})$, or $\mathrm{Mn}(\mathrm{II})^{3}$, (ii) a $\mathrm{pH}$ in the range of $6.5-8.5$, and (iii) a temperature in the range of $40-90^{\circ} \mathrm{C}$. In addition, it is known that the catalytic effect of glucose isomerase is inhibited by $\mathrm{Cu}(\mathrm{II}), \mathrm{Hg}(\mathrm{II}), \mathrm{Ni}(\mathrm{II}), \mathrm{Ag}(\mathrm{I})$ and to some extent by $\mathrm{Ca}(\mathrm{II}), \mathrm{D}$-xylitol, D-mannitol and D-glucito ${ }^{4}$. In this chapter first a literature survey is given of the history of glucose isomerase, its mechanism of isomerization and the properties of commercially available immobilized glucose isomerases. Subsequently, experiments are described in which glucose isomerase is subjected to various reaction conditions. This to establish the limitations in reaction conditions of the above-mentioned 'combi-process'.

\section{Literature survey of glucose isomerase}

History

During the early 1950's, several monosaccharide isomerizing enzymes were observed in animal tissues and bacteria. A significant discovery of

\footnotetext{
* Accepted for publication in 'Starch'.
} 
Marshall and Kooi ${ }^{5}$ was the observation that the enzyme 'xylose isomerase' from Pseudomonas hydrophita, which interconverts $D$-xylose and D-xylulose, also isomerizes D-glucose to D-fructose. However, from the required presence of arsenate in the reaction mixture for obtaining a proper D-glucose $\rightleftharpoons \mathrm{D}$-fructose conversion as well as from the ability to isomerize D-glucose-6-phosphate into D-fructose-6-phosphate in the absence of arsenate, it was concluded that this enzyme was a D-glucose6-phosphate isomerase (E.C. 5.3.1.9; D-glucose-6-phosphate ketol isomerase $)^{6}$. This fact, and the fact that the formation of xylose isomerase was absolutely dependent on the presence of $\mathrm{D}$-xylose in the growth medium meant that this enzyme could not be exploited commercially. Since then a great number of other glucose isomerases (D-xylose ketol isomerase; E.C. 5.3.1.5), which do not need arsenate in the reaction mixture for the interconversion of D-glucose and D-fructose, have been discovered. In particular, glucose isomerases derived from Lactobacillus sp., Streptomyces sp., Actinoplanes missouriensis, Bacillus coagulans and Arthrobacter sp., have been investigated. Most of these bioorganisms use relatively inexpensive carbon sources such as beet molasses, wheat bran or corn starch in their growth medium. The production, extraction and purification of glucose isomerases from these sources have been reviewed ${ }^{7}, 8,9$.

Glucose isomerase and its mechanism of isomerization

The molecular weight of the different glucose isomerases varies from 52.000 for species from Streptomyces bikiniesis ${ }^{10}$ to as high as 190.000 for species from Lactobacillus brevis ${ }^{11}$. Treatment of various glucose isomerases with guanidine. $\mathrm{HCl}$ shows that the enzyme may be considered, as a rough approximation, to be built up by one to four subunits with a molecular weight of $40.000-50.000^{10,12,13,14}$. The isolated subunits derived from Streptomyces olivochromogenes ${ }^{10}$, Streptomyces griseofuscus $^{14}$ and Bacillus strearothermophiles ${ }^{10}$ possess, however, no isomerizing properties. Furthermore, the amino acid composition of Streptomyces albus ${ }^{12}$ and Bacillus coagulans ${ }^{13}$ is completely different from each other, although the molecular weight of the isolated subunit of both enzymes lies in the range of $40.000-45.000$. These similar, or maybe identical, subunits are associated by non-covalent bonds. Dimeric species are obtained from Actinoplanes missouriensis ${ }^{15}$ (MW $=80.000$ ) whereas tetrameric species occur in Streptomyces albus ${ }^{12}($ MW $=157.000)$ and Bacillus coagulans ${ }^{13}(M N=163.000)$. At present, it is not obvious whether such subunit combinations count for more than one active site.

Glucose isomerase requires $\mathrm{Mg}$ (II), $\mathrm{Co}$ (II), $\mathrm{Mn}$ (II) or a combination thereof for its catalytic activity as well as for its protection against heat denaturation. Studies of the mechanism of the reaction catalyzed by glucose isomerases derived from Lactobacillus brevis and Streptomyces species indicate that there is a binding of $\mathrm{Mn}$ (II) at the active site of the enzyme ${ }^{16}$. Both $\mathrm{Mg}$ (II) and $\mathrm{Co}$ (II) are found to be of importance in order to obtain a high activity of glucose isomerase from Actinoplanes missouriensis: $\mathrm{Mg}$ (II) proves to be essential for the enzyme, whereas $\mathrm{Co}$ (II) further enhances the activity ${ }^{17}$. For glucose isomerase obtained from Streptomyces phaechromogenes the optimum temperature is raised from $80{ }^{\circ} \mathrm{C}$ to $90^{\circ} \mathrm{C}$ when $\mathrm{Co}$ (II) is added to the Mg(II)-containing solution ${ }^{18}$. on the other hand, for a glucose isomerase species derived from Bacillus coagulans $\mathrm{Co}(\mathrm{II})$ is essential for the enzyme, whereas $\mathrm{Mg}$ (II) further enhances the activity ${ }^{19}$. Since $C($ II) is not allowed in the final product, the practical use of glucose isomerases is restricted to those enzyme preparations which are active and stable in the presence of only $\mathrm{Mg}$ (II). Relative high $\mathrm{Mg}(\mathrm{II})$ concentrations $\left(10^{-4}-10^{-2} \mathrm{M}\right)$ are applied. At $\mathrm{Mg}(\mathrm{II})$ concentrations $>10^{-2} \mathrm{M}$ the enzyme activity of Actinoplanes missouriensis was not further enhanced ${ }^{15}$. As extra addition of $\mathrm{Mg}$ (II) results in higher costs for both the isomerization process and the purification procedure, the ultimate choice of $\mathrm{Mg}$ (II) concentration will be a compromise between these additional expenses and profits by enhanced enzymatic activity and enzyme half lifetime.

Various carbohydrates and related compounds have been examined as the reactant for the enzyme. In addition to D-glucose and D-xylose, also D-ribose, L-arabinose, D-allose and D-galactose are isomerized by glucose isomerase with a measurable rate. These sugars have in common the presence of a $C_{1}-\alpha$-pyranose structure and an equatorial hydroxyl group at $\mathrm{C}-2$. When the $3-\mathrm{OH}$ and $4-\mathrm{OH}$ groups are in an equatorial position, as in the case for $D$-glucose and $D$-xylose, relatively high isomerization rates are observed as shown. in Table $\mathrm{I}^{17,20}$.

It has been indeed demonstrated by ${ }^{1} \mathrm{H}$ NMR and ${ }^{13} \mathrm{C}$ NMR that glucose iomerase is specific for the a-pyranose form of D-xylose ${ }^{21}$ and $D-g l u-$ $\operatorname{cose}^{22}$. The enzymatic isomerization of D-xylose to $\mathrm{D}$-xylulose and of D-glucose to D-fructose involves a 1,2-proton shift without exchange with the solvent ${ }^{21,22}$. The proposed mechanism suggests that a metal ion 
TABLE I

Reactant specificity of glucose isomerase from Actinoplanes missourien$\operatorname{sis}^{\mathrm{a}}, 17$

Reactant Relative initial rate of ketose formation $(\mathrm{mol} / \mathrm{h})^{b}$

\begin{tabular}{ll}
\hline D-Glucose & 0.325 \\
D-Galactose & 0.015 \\
D-Mannose & 0.000 \\
D-Xylose & 0.158 \\
D-Ribose & 0.052 \\
D-Arabinose & 0.000
\end{tabular}

a $1 \mathrm{M}$ reactant; $3 \cdot 10^{-3} \mathrm{M} \mathrm{Mg}$ (II); $3 \cdot 10^{-4} \mathrm{M} \mathrm{Co}$ (II); $\mathrm{pH}=7.5 ; 75^{\circ} \mathrm{C}$.

b Amount of enzyme-(not specified) was kept constant.

participates in the binding of the reactant at the active site of the enzyme through a metal-bridge complex. The enzyme-bound metal ion is believed to coordinate bidentately with the 1 - and $2-0 \mathrm{H}$ groups of the $\alpha$-pyranose form of D-glucose and D-xylose, thus facilitating proton removal at $\mathrm{C}-2$ by a basic group of the enzyme. This leads to the formation of a cis-enediol intermediate ${ }^{25}$ with subsequent transfer of the same proton from the enzyme to $\mathrm{C}-1$. It is generally assumed that the $\beta$-D-fructofuranose structure is formed initially ${ }^{7,22,23}$. Critical examination of molecular models, however, shows that initial $\alpha$-D-fructofuranose formation would be expected from the cis-enediol intermediate. This was experinentally established by the enzymatic isomerization of $1-{ }^{13} \mathrm{C}$ D-glucose at $66{ }^{\circ} \mathrm{C}^{26}$. The initial ratio of $\alpha-D$-fructof uranose/ $\beta-D-f$ ructofuranose proved to be about 1.0 as determined by ${ }^{13} \mathrm{C}$ NMR, which is substantially higher than the equilibrium value $(0.3)$ under the same conditions. The mechanism of the interconversion of D-glucose an D-fructose is illustrated in Fig. $1^{26}$. Using the principle of the least molecular motion, attack of $0-5$ of the cis-enediol intermediate, which will be accompanied by hydrogen addition, will give either $\alpha-D-g l u c o-$ pyranose or $a-D$-fructofuranose.

This mechanism fully explains the observations ${ }^{22}$ of the stereospecific $(S)$ - and $(R)-1-{ }^{2} \mathrm{H}-\mathrm{D}-\mathrm{f}$ ructose formation upon enzymatic isomerization of $1-$ and $2{ }^{2} \mathrm{H}-\mathrm{D}-\mathrm{g} 1$ ucose, respectively. The suggestions made by Laszlo et at. ${ }^{27}$ that the acyclic form is the reactive species for the

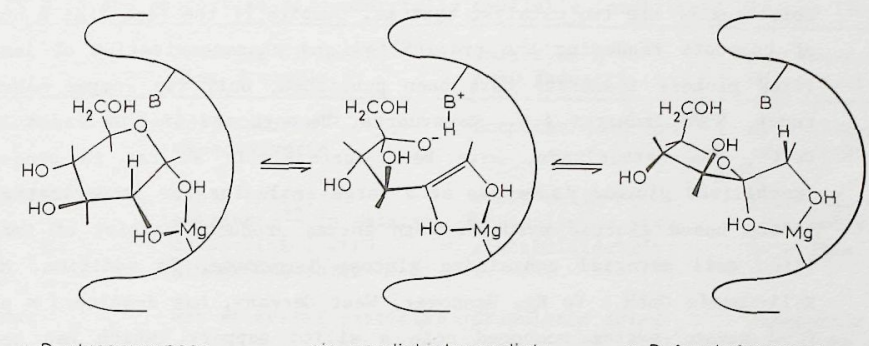

$\alpha-D$-glucopyranose

cis-enediol intermediate

$\alpha$-D-fructofuranose

Fig. 1. Mechanism of the interconversion of D-glucose and D-fructose by the enzyme glucose isomerase (E.C. $5 \cdot 3 \cdot 1 \cdot 5)^{26}$.

enzyme glucose isomerase, are not consistent with other studies and our observations.

The isomerization of D-glucose to D-fructose is reversible. The equilibrium constant

$$
K^{*}=\frac{[F]_{e}}{[G]_{e}}=1.00
$$

at $58{ }^{\circ} \mathrm{C}$ and has been reported to increase by 0.08 unit for each rise in temperature of $10^{\circ} \mathrm{C}^{28}$.

Commercially available inmobilized glucose isomerases

Glucose isomerase, nowadays one of the most important enzymes for industrial use, has received extensive attention during the past decade. Since the isomerization of $\mathrm{D}-\mathrm{glucose}$ to $\mathrm{D}$-fructose is a simple reaction, i.e. (i) the reactant is a relatively small molecule, (ii) no pH-change, (iii) no reactant inhibition, and (iv) no cofactors required, it was readily achieved to use immobilized glucose isomerase in a continuous flow reactor. The use of immobilized glucose isomerase in this way has great advantages over the use of soluble glucose isomerase, since the product formation can be controlled more strictly and the separation of the enzyme from the reaction mixture is simple. In our approach of combined action of glucose isomerase with a hydrogenation catalyst in order to convert D-glucose or D-glucose/D-fructose mixtures into D-mannitol, 
immobilization of the enzyme is required in order to prevent serious poisoning of the two catalyst systems. Despite of the fact that a number of accounts regarding the preparation and characterization of immobilized glucose isomerase have been published, only two enzyme manufactures, Novo Industri A.s., Bagsvaerds, Denmark and Gist Brocades N.V., Delft, The Netherlands, have been successfully so far in producing immobilized glucose isomerase at a large scale for the isomerization of starch based glucose syrups ${ }^{9}$. Both enzyme products consist of immobilized cell material containing glucose isomerase. In addition, Miles Kali-Chemie GmbH \& Co Kg, Hannover, West Germany, has developed a purified enzyme system anchored onto a silica support, which has become commercially available quite recently.

Properties of immobilized glucose isomerases

A summary of the properties of these immobilized enzyme systems, together with their sources and immobilization methods, is given in Table II.

The effect of $\mathrm{pH}$ on the initial activity and the stability of Maxazyme GI-Immob., Sweetzyme $Q$ and, as far as known, Optisweet 22 is illustrated in Figs. 2 and $3^{29-31}$. As a compromise between activity and stability of the enzyme, a $\mathrm{pH}$ of 7-8 should be preferentially chosen. In order to fulfil this $\mathrm{pH}$ demand during the simultaneous enzymatic isomerization and hydrogenation of invert sugar the use of a small amount of solid $\mathrm{CaCO}_{3}$ as the buffer would seem convenient to protect the system

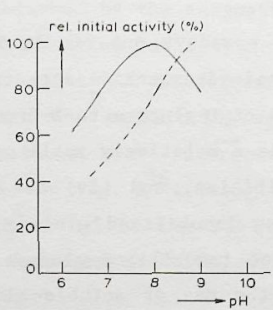

Fig. 2. The influence of $\mathrm{pH}$ on the initial activity of immobilized glucose isomerase 29,30 .

$(\longrightarrow$, Sweetzyme Q; (---) ), Maxazyme GI-Immob.
TABIE

Summary of data and properties of commercially available immobilized glucose isomerase

\begin{tabular}{|c|c|c|c|}
\hline $\begin{array}{l}\text { Trade name } \\
\text { Company }\end{array}$ & $\begin{array}{l}\text { Maxazyme GI-Immob. }{ }^{29} \\
\text { Gist Brocades }\end{array}$ & $\begin{array}{l}\text { Sweetzyme } 0^{30,34} \\
\text { Novo Industri }\end{array}$ & $\begin{array}{l}\text { Optisweet } 22^{31} \\
\text { Miles Kali-Chemie }\end{array}$ \\
\hline Enzyme source & $\begin{array}{l}\text { Actinoplanes }{ }^{35} \\
\text { missouriensis }\end{array}$ & Bacillus coagulans 36 & $\begin{array}{l}\text { Streptomyces } \\
\text { ribiginosus }\end{array}$ \\
\hline $\begin{array}{l}\text { Immobilization } \\
\text { method }\end{array}$ & $\begin{array}{l}\text { Whole cells, } \\
\text { entrapped } 32 \text { in gelatin, } \\
\text { cross-linked with } \\
\text { glutardialdehyde }\end{array}$ & $\begin{array}{l}\text { Whole cells }{ }^{33} \text {, } \\
\text { cross-linked with } \\
\text { glutardialdehyde }\end{array}$ & $\begin{array}{l}\text { Purified enzyme, } \\
\text { covalently bound } \\
\text { on silica }\end{array}$ \\
\hline Performance & Wet spherical particles & $\begin{array}{l}\text { Granulated dried } \\
\text { cylindrical particles }\end{array}$ & $\begin{array}{l}\text { Suspension of } \\
\text { spherical particles }\end{array}$ \\
\hline Reactant (reported) & $\begin{array}{l}\text { D-Xylose, D-Ribose } 17 \\
\text { D-Allose, D-Galactose, } \\
\text { D-Glucose }\end{array}$ & $\begin{array}{l}\text { D-Xylose } 1,13 \\
\text { D-Ribose, D-Glucose }\end{array}$ & D-Glucose \\
\hline $\mathrm{T}$ (max. activity) & $90{ }^{\circ} \mathrm{C}^{17,32}$ & $83^{\circ} \mathrm{C}^{30}$ & - \\
\hline$T$ (recommended) & $60^{\circ} \mathrm{C}^{29}$ & $60^{\circ} \mathrm{C}^{30}$ & $60^{\circ} \mathrm{C}$ \\
\hline $\mathrm{pH}$-range & $6-9^{29}$ & $5-9^{30}$ & -- \\
\hline $\mathrm{pH}$ (recommended) & $7.5^{29}$ & $8.2^{30}$ & 7.5 \\
\hline $\begin{array}{l}\text { Cation requirement } \\
\text { (recommended) }\end{array}$ & $3.10^{-3} \mathrm{M} \mathrm{Mg}(\mathrm{II})^{29}$ & $4 \cdot 10^{-4} \mathrm{M} \mathrm{Mg}(\mathrm{II})^{34}$ & $5.10^{-3} \mathrm{M} \mathrm{Mg}$ (II) \\
\hline $\begin{array}{l}\text { Inhibitors } \\
\text { (reported) }\end{array}$ & $\begin{array}{l}\mathrm{Ag}(\mathrm{I}), \mathrm{Ni}(\mathrm{II})^{29}, \\
\mathrm{Hg}(\mathrm{II}), \mathrm{Al}(\mathrm{III}), \\
\mathrm{Fe}(\mathrm{II}), \mathrm{Zn}(\mathrm{II}), \mathrm{Ca}(\mathrm{II})\end{array}$ & $\begin{array}{l}\mathrm{Cu}(\mathrm{II}), \mathrm{Ni}(\mathrm{II})^{34}, \\
\mathrm{Ca}(\mathrm{II}), \mathrm{Zn}(\mathrm{II}), \\
\mathrm{Ba}(\mathrm{II}), \mathrm{Hg}(\mathrm{II}), \mathrm{As}(\mathrm{II})\end{array}$ & $\mathrm{Ca}(\mathrm{II})$ \\
\hline $\begin{array}{l}\text { Half lifetime (at } \\
\text { recommended } \\
\text { conditions) }\end{array}$ & $1300 h^{29}$ & $1050 h^{34}$ & $1200 \mathrm{~h}$ \\
\hline $\begin{array}{l}\text { Productivity at } \\
\text { half lifetime ( } \mathrm{kg} \\
\text { dry product/kg dry } \\
\text { enzyme preparation) }\end{array}$ & $2430^{29}$ & $1430^{34}$ & 13000 \\
\hline Molecular weight & $80.000^{15}$ & 100.000 & 160.000 \\
\hline $\begin{array}{l}\text { Enzyme content of } \\
\text { enzyme preparation }\end{array}$ & $6-7 \%$ & $12 \%$ & $7-8 \%$ \\
\hline Activity & 0.044 & 0.116 & 0.617 \\
\hline $\begin{array}{l}\text { Apparent turn over } \\
\text { number }\left(\mathrm{s}^{-1}\right)^{\mathrm{b}}\end{array}$ & 50 & 30 & 360 \\
\hline
\end{tabular}

See experimental part, section procedure and calculation. $0.617 \mathrm{M}$ D-glucose; 1.0

b Immobilized glucose isomerase; $10^{-2} \mathrm{M} \mathrm{Mg}$ (II); $10^{-4} \mathrm{M} \mathrm{Ca}$ (II) $; 70.2{ }^{\circ} \mathrm{C} ; \mathrm{pH}=7.1 ; \mathrm{H}_{2} \mathrm{O}$.

Number of D-glucose molecules, which are converted per molecule enzyme per second as and the molecular enzme activity, the enzyme content of the immobilized glucose isomerase 


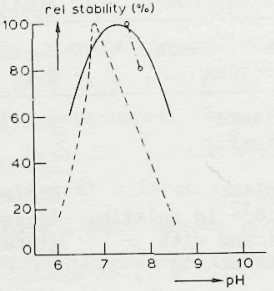

Fig. 3. The influence of $\mathrm{pH}$ on the stability of immobilized glucose isomerase, regarding half-lifetime $29-31$.

$(\longrightarrow$, Sweetzyme Q; (---), Maxazyme GI-Immob.; (0-.-0), Optisweet 22 .

against trace amounts of acidic degradation products formed. The possibility of some inhibitory effect by $\mathrm{Ca}$ (II), however, should be envisaged.

The influence of temperature on both the initial activity and the half lifetime of Maxazyme GI-Immob., Sweetzyme $Q$ and, as far as known, optisweet 22 is shown in Figs. 4 and $5^{9,17,29-32}$. The temperature to achieve maximum activity is somewhat higher for Maxazyme GI-Immob. $\left(90^{\circ} \mathrm{C}\right)^{32}$ than for Sweetzyme $\mathrm{Q}\left(83^{\circ} \mathrm{C}\right)^{30}$. The influence of temperature on the half lifetime for both enzymes is more or less the same. Although the choice of temperature is a compromise between the activity and life

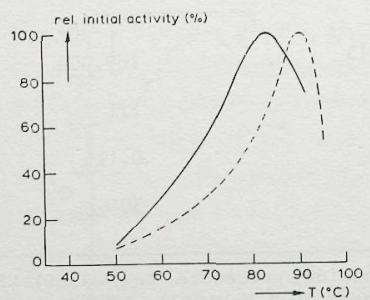

Fig. 4. The influence of temperature on the initial activity of immobilized glucose isomerase $17,30,32$.

$(\longrightarrow$, Sweetzyme Q; (---), Maxazyme GI-Immob.

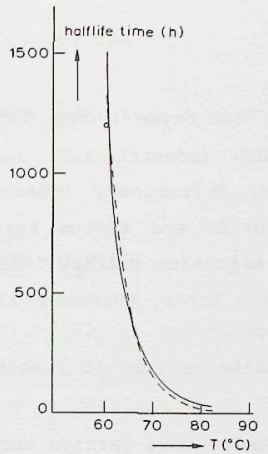

Fig. 5. The influence of temperature on the stability of immobilized glucose isomerase, regarding half-1ifetime $9,30,31$.

$(\longrightarrow$, Sweetzyme Q; (---), Maxazyme GI-Immob.; (o), Optisweet 22 .

time that is required, the region will be limited from $55-75{ }^{\circ} \mathrm{C}$. For the present combi-process a relatively high temperature $\left(70{ }^{\circ} \mathrm{C}\right)$ has been chosen in order to retain for an acceptable hydrogenation activity of the metal catalyst.

Apart from $\mathrm{pH}$ and temperature, the hydrogenation reaction requires conditions which will largely deviate from those for the production of high fructose corn syrups. Therefore, the influence of hydrogen pressure, $\mathrm{Mg}$ (II), $\mathrm{Ca}$ (II), transition metal ions, borate (used as an additive) and hydrogenation products (D-glucitol and D-mannitol) on the activity of immobilized glucose isomerase has been investigated. Maxazyme GI-Immob. and Sweetzyme $Q$ have been taken as examples of immobilized cells, Optisweet 22 as an example of an immobilized isolated enzyme species. The results of this study are given in this chapter. 
Materials

Maxazyme GI-Immob., Sweetzyme Q and optisweet 22 were gifts from Gist Brocades N.V., NovO Industri A.S, and Miles Kali-Chemie K.G., respectively. D-Glucose, D-fructose, D-mannitol, D-glucitol, calcium carbonate, calcium chloride and sodium tetraborate were supplied by Merck. Copper nitrate, magnesium sulfate, magnesium chloride and nickel nitrate were obtained from Baker, ruthenium trichloride from Alfa.

Apparatus

The activity experiments were carried out in a $150 \mathrm{ml}$ vessel equipped with a pH-electrode (Broadly James Corp. 9093-HT 3) connected to a pH-meter (Metrohm, 632), a dosimat (Metrohm, E 535) and a magnetic stirrer. The $\mathrm{pH}$ was kept constant at 7.1 with an impulsomat (Metrohm, 614). The reaction vessel was equipped with a thermostat jacket and was kept at $70.2 \pm 0.2{ }^{\circ} \mathrm{C}$.

Procedure

The immobilized glucose isomerase $(1.000 \mathrm{~g}), 90 \mathrm{ml}$ of deionized water and the selected additive(s) were placed in the reaction vessel. After one hour incubation $10.000 \mathrm{~g}$ of $\mathrm{D}$-glucose was added. The conversion was followed by taking samples of $0.1 \mathrm{~m} 1$ at suitable intervals and analyzing the samples by means of high performance liquid chromatography (HPLC).

Analysis method

The HPLC system consisted of an M 6000 A pump (Waters Assoc.), a Rheodyne 7125 injector, an $R 401$ differential refractometer (Waters Assoc.), an SP 4100 integrator (Spectro Physics) and a cation-exchange resin column. Chromatographic conditions: column dimensions: $30 \mathrm{~cm} * 7.0$ $\mathrm{mm}$ ID; Aminex A $78 \%$ cross-linked resin $(7-11 \mu \mathrm{m})$ in the $\mathrm{Ca}$ (II)-form; temperature: $85{ }^{\circ} \mathrm{C}$; flow rate: $0.6 \mathrm{ml} / \mathrm{min}$; eluent: degassed and deionized $\mathrm{H}_{2} \mathrm{O}$. The chromatographic procedure is described in more detail elsewhere ${ }^{37}$
The enzymatic interconversion

$$
\text { D-glucose } \underset{k_{2}}{\stackrel{k_{1}}{\rightleftharpoons}} \text { D-fructose }\left(G \underset{\frac{k_{2}}{k_{2}}}{\stackrel{k_{1}}{\rightleftharpoons}}\right. \text { F) }
$$

may be expressed as

$$
-\frac{d[G]}{d t}=\frac{d[F]}{d t}=k_{1} w[G]-k_{2} w[F]
$$

with $[G]=[G]_{e}$ and $[F]=[F]_{e}$ at $t=\infty$, whereas $[G]=[G]_{0}$ and $[F]=0$ at $t=0$ if the experiment is started with $D-g l$ ucose as the reactant, and $w=$ weight of enzyme preparation in $g$. Using the mass balance

$$
[G] \circ-[G]=[F]
$$

we get as the kinetic expression

$$
-\frac{d[G]}{d t}=\left(k_{1}+k_{2}\right) w[G]-k_{2} w[G] 。
$$

or, in the integrated form,

$$
\ln \frac{k^{*}[G]_{0}}{\left(K^{*}+1\right)[G]-[G]_{0}}=k_{1} w\left(1+1 / K^{*}\right) t
$$

with $K^{*}=\frac{[F]_{e}}{[G]_{e}}=\frac{k_{2}}{k_{1}}$ as the equilibrium constant.

The rate constant $k_{1}$ is calculated by means of this integrated form of the kinetic expression, using the least squares method.

The activity of immobilized glucose isomerase is defined as the initial rate

$$
\left(-\frac{\mathrm{d}[\mathrm{G}]}{\mathrm{dt}}\right)_{\mathrm{t}=0}=\mathrm{k}_{1} \mathrm{w}[\mathrm{G}]_{0} \text { at }[\mathrm{G}]_{0}=0.617(=10 \% \mathrm{w} / \mathrm{w})
$$

as obtained from the experimental data by extrapolation to $t=0$. 
Results and discussion

D-Glucose/D-fructose equilibrivm constant

In order to calculate the rate constant $k_{1}$ we have to know the equilibriun constant

$$
K^{*}=\frac{[F]_{e}}{[G]_{e}}
$$

under the conditions used. Therefore, the equilibrium concentration ratios of $D$-glucose and $D$-fructose have been determined in the total concentration range of $0.3-2.2 \mathrm{M}$ using Maxazyme GI-Immob., Sweetzyme Q and optisweet 22 (Table III).

TABLE III

Equilibrium constant $\mathrm{K}^{*}$ at different total D-glucose/D-fructose concentration $^{\mathrm{a}}$

\section{$\mathrm{K}^{*}$}

\begin{tabular}{cc}
$\begin{array}{c}\text { Total concentration } \\
(\mathrm{M})\end{array}$ & $\mathrm{K}^{*}$ \\
\hline 0.278 & 1.110 \\
0.555 & 1.109 \\
0.617 & 1.107 \\
0.833 & 1.114 \\
1.111 & 1.104 \\
1.667 & 1.104 \\
2.222 & 1.105 \\
\end{tabular}

a $1.00 \mathrm{~g}$ enzyme; $V_{\text {tot }}=100 \mathrm{ml} ; \mathrm{H}_{2} \mathrm{O} ; \mathrm{pH}=7.1 ; \mathrm{T}=70.2{ }^{\circ} \mathrm{C} ; 10^{-2} \mathrm{M}$ $\mathrm{Mg}(\mathrm{II})$.

The data show that in the equilibrium constant $K^{*}$ is independent of the total D-glucose/D-fructose concentratio. This allowed the use of $K^{*}=$ 1.107 throughout the calculation of the activity of immobilized glucose isomerase at $70^{\circ} \mathrm{C}$.
Hydrogen pressure

Since the hydrogenation of invert sugar takes place under hydrogen pressure, its influence on the activity of Maxazyme GI-Immob. has been examined. The curves of the conversion of D-glucose towards D-fructose as a function of time at different hydrogen pressures are presented in Fig. 6. It was found that in the pressure range of $1-75 \mathrm{~kg} / \mathrm{cm}^{2}$ the hydrogen pressure has no influence on the activity of Maxazyme GI-Immob. In the course of our work another example of the influence of $\mathrm{H}_{2}$-pressure was reported for the enzymes $\alpha$-amylase and $\beta$-amylase ${ }^{38}$. Here both the presence of hydrogen and high pressure caused a slight decrease in the activity of $\alpha$-amylase and $\beta$-amylase.

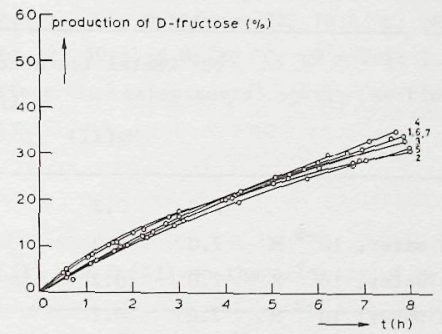

Fig. 6. The influence of hydrogen pressure on the activity of Maxazyme GI-Inmob.

$0.617 \mathrm{M} \mathrm{D}-\mathrm{g} l$ lucose, $1.0 \mathrm{~g}$ Maxazyme GI-Immob., $10^{-2} \mathrm{M} \mathrm{Mg}$ (II), $10^{-4}$ $\mathrm{MCa}(\mathrm{II}), 70.2{ }^{\circ} \mathrm{C}, \mathrm{pH}=7.1, \mathrm{H}_{2} \mathrm{O}$. Blank (1), $\mathrm{P}_{\mathrm{H} 2} 1$ (2), 10 (3), $25(4), 40(5), 50(6)$ and $75(7) \mathrm{kg} / \mathrm{cm}^{2}$.

The influence of $\mathrm{Mg}$ (II) and $\mathrm{Ca}(\mathrm{II})$

Extraction of Optisweet 22 with EDTA shows that glucose isomerase contains $\mathrm{Mg}$ (II) and trace amounts $\mathrm{Co}$ (II) and $\mathrm{Mn}$ (II) (Table IV). The value of $6.8 \mathrm{ppm} \mathrm{Mg}$ (II) corresponds with about 6 atoms $\mathrm{Mg}$ (II) per enzyme molecule $(M W=160.000)$, i.e. at least one $\mathrm{Mg}(\mathrm{II})$ per subunit. Although the coordination between $\mathrm{Mg}$ (II) and the enzyme ${ }^{40}$ will be much stronger than the coordination between $\mathrm{Mg}$ (II) and invert sugar ( $1: 1 \mathrm{D}$-glucose/Dfructose mixture) ${ }^{46}$, substantial accumulation of $\mathrm{Mg}$ (II) in solution occurs at high invert sugar concentrations (Table IV). 
The observed $\mathrm{Mg}$ (II) extraction of the enzyme by aqueous invert sugar explains the requirement of the use of $\mathrm{Mg}$ (II)-containing D-glucose corn syrups in order to maintain full enzyme activity 15,17 .

Another metal ion that plays an important role in the production of high D-fructose corn syrups is Ca(II). For the production of D-glucose syrups two types of enzymes ( $\alpha$-amylase for the liquefaction of starch into dextrins and amyloglucosidase for the saccharification of dextrins into $\mathrm{D}$-glucose) are used in the industrial starch degradation. $\alpha$-Amylase requires calcium metallo-enzyme: the addition of $\mathrm{Ca}$ (II) or the use of tap water has an activating and stabilizing influence.

TABLE IV

Extraction of metal ions from Optisweet $22^{\text {a }}$

\begin{tabular}{lrlll}
\hline Medium & $\mathrm{pH}$ & Metal ion concentration in solution \\
& & $\mathrm{Mg}(\mathrm{II})$ & $\begin{array}{c}(\mathrm{ppm}) \\
\mathrm{Co}(\mathrm{II})\end{array}$ & $\mathrm{Mn}$ (II) \\
\hline Water & 7.0 & 0.2 & & \\
Invert sugar in water, $10^{-4} \mathrm{M}$ & 7.0 & 0.2 & & \\
Invert sugar in water, $10^{-3} \mathrm{M}$ & 7.0 & 0.2 & & \\
Invert sugar in water, $10^{-2} \mathrm{M}$ & 7.0 & 0.2 & & \\
Invert sugar in water, $10^{-1} \mathrm{M}$ & 7.0 & 0.6 & & 0.1 \\
Invert sugar in water, 1 M & 7.0 & 2.8 & & \\
Invert sugar in water, 3 M & 7.0 & 4.2 & & \\
EDTA in water, 1 M & 10.5 & 6.8 & 0.5 & \\
\hline
\end{tabular}

a $5.0 \mathrm{~g}$ Optisweet $22 ; 50 \mathrm{ml}$ solution; $20^{\circ} \mathrm{C} ; 1 \mathrm{~h}$.

Calcium, however, has to be removed from D-glucose syrups thus obtained, since it has been shown to act as an inhibitor for glucose isomerase ${ }^{32}$

The inhibitory effect will be due to exchange of $\mathrm{Mg}$ (II) by $\mathrm{Ca}$ (II) at the active centre of the enzyme, as clearly demonstrated by the strong accumulation of $\mathrm{Mg}$ (II) in solution when $\mathrm{Ca}$ (II) is added to a suspension of Optisweet 22 in water (Table V). The complete deactivation of the enzyme, Optisweet 22, even at low $\mathrm{Ca}$ (II)-Mg(II) exchange, is noteworthy. Exchange of $\mathrm{Mg}(\mathrm{II})$ for $\mathrm{Ca}(\mathrm{II})$ at one of the four subunits is perhaps sufficient to inhibit the enzyme action.

The effect of $\mathrm{Mg}$ (II) and $\mathrm{Ca}(\mathrm{II})$ on the activity of Maxazyme GI-Immob. is given in Table VI. $\mathrm{Mg}$ (II) enhances the activity of the
TABLE V

Influence of $\mathrm{Ca}$ (II) on the activity ${ }^{\mathrm{a}}$ of and the extraction of $\mathrm{Mg}$ (II) ${ }^{\mathrm{b}}$ from Optisweet 22 .

\begin{tabular}{cccc}
\hline $\begin{array}{c}\mathrm{Ca}(\mathrm{II}) \\
(\mathrm{ppm}) \text { (added) }\end{array}$ & $\begin{array}{c}\mathrm{Mg} \text { (II) } \\
\text { (ppm) (found) }\end{array}$ & $\begin{array}{c}\text { Activity } \\
\left(\mathrm{mol} . \mathrm{h}^{-1} \mathrm{~g}^{-1}\right)\end{array}$ & $\begin{array}{c}\text { Rel. activity } \\
(\%)\end{array}$ \\
\hline-- & 0.5 & 0.131 & 100 \\
12 & 2.2 & 0 & 0 \\
60 & 4.2 & 0 & 0 \\
400 & 6.6 & 0 & 0 \\
4000 & 6.8 & 0 & 0 \\
\hline
\end{tabular}

a $0.617 \mathrm{M} \mathrm{D}-$ glucose; $1.0 \mathrm{~g}$ optisweet $22 ; 70.2{ }^{\circ} \mathrm{C} ; \mathrm{pH}=7.1 ; \mathrm{H}_{2} \mathrm{O}$.

b $5.0 \mathrm{~g}$ Optisweet $22 ; 50 \mathrm{ml} \mathrm{H} 20 ; 20{ }^{\circ} \mathrm{C} ; \mathrm{pH}=7.1 ; 1 \mathrm{~h}$.

c Activity, defined in experimental part, section calculation of enzyme activity.

TABLE VI

Influence of $\mathrm{Mg}$ (II) and $\mathrm{Ca}(\mathrm{II})$ on the activity of Maxazyme GI-Immob. ${ }^{\mathrm{a}}$

\begin{tabular}{lccc}
\hline Additive & $\begin{array}{c}\text { Concentration } \\
(\mathrm{M})\end{array}$ & $\begin{array}{c}\text { Activity } \\
\left(\mathrm{mol} . \mathrm{h}^{-1} \mathrm{~g}^{-1}\right)\end{array}$ & $\begin{array}{c}\text { Rel. activity } \\
(\%)\end{array}$ \\
\hline- & -- & 0.046 & 100 \\
$\mathrm{MgSO}_{4}$ & $10^{-3}$ & 0.048 & 104 \\
$\mathrm{MgSO}_{4}$ & $10^{-2}$ & 0.059 & 128 \\
$\mathrm{MgCl}_{2}$ & $10^{-2}$ & 0.060 & 130 \\
$\mathrm{CaCl}_{2}$ & $10^{-4}$ & 0.034 & 74 \\
$\mathrm{CaCl}_{2}$ & $10^{-3}$ & 0.015 & 33 \\
$\mathrm{CaCl}_{2}$ & 5 & 0.010 & 22 \\
$\mathrm{CaCl}_{2}$ & $10^{-3}$ & 0.007 & 15 \\
$\mathrm{CaCl}_{2}$ & $10^{-2}$ & 0.003 & 6 \\
$\mathrm{NaCl}^{-1}$ & $10^{-1}$ & 0.044 & 96 \\
\hline
\end{tabular}

a $0.617 \mathrm{M} \mathrm{D}$-Glucose; $1.0 \mathrm{~g}$ Maxazyme GI-Immob.; $70.2{ }^{\circ} \mathrm{C} ; \mathrm{pH}=7.1$; $\mathrm{H}_{2} \mathrm{O}$. 
enzyme, whereas $\mathrm{Ca}$ (II) causes a strong decrease in activity. However, the glucose isomerase in its cellular environment and encapsulated in a gelatin-glutardialdehyde matrix (Maxazyme GI-Immob.) proves to be much better protected against $\mathrm{Ca}(\mathrm{II})$ than the isolated glucose isomerase attached to silica (Optisweet 22).

Simultaneous enzymatic interconversion and hydrogenation of D-glucose/D-fructose mixtures will be accompanied with the formation of small quantities of acidic degradation products, resulting in a decrease of $\mathrm{pH}$. In order to keep the $\mathrm{pH}$ at the required level during the hydrogenation in the autoclave, as a prerequisite for optimum activity of the enzyme and for the protection of the hydrogenation catalyst, a small amount of solid $\mathrm{CaCO}_{3}$ as an inexpensive buffer is added. Although the solubility of $\mathrm{CaCO}_{3}$ as such in water at $70{ }^{\circ} \mathrm{C}$ is rather low $\left(\sim 10^{-4} \mathrm{M}\right)$, trace amounts of acidic degradation products formed will increase the $\mathrm{Ca}(\mathrm{II})$ concentration to $10^{-3} \mathrm{M}$ as determined with A.A.S. With Maxazyme GI-Immob. the use of $\mathrm{CaCO}_{3}$ as a buffer is just acceptable, whereas for Optisweet 22 this will be not.

Fortunately, the inhibitory effect of $\mathrm{Ca}$ (II) can be largely overcome by extra addition of $\mathrm{Mg}$ (II) as shown in Table VII and Fig. 7 for Maxazyme GI-Immob. A similar reactivating effect of $\mathrm{Mg}$ (II) is observed for Optisweet 22 (restore of activity in the presence of $10^{-4} \mathrm{M} \mathrm{Ca}$ (II) by addition of $10^{-2} \mathrm{M} \mathrm{Mg}($ II $)$ ).

TABLE VII

Influence of $\mathrm{CaCO}_{3}$ on the activity of Maxazyme GI-Immob. ${ }^{2}$

\begin{tabular}{|c|c|c|c|c|c|}
\hline \multirow{2}{*}{\multicolumn{2}{|c|}{ Additive }} & \multicolumn{2}{|c|}{ Concentration (M) } & \multirow{2}{*}{$\begin{array}{c}\text { Activity } \\
\left(\text { mol. } \mathrm{h}^{-1} \mathrm{~g}^{-1}\right)\end{array}$} & \multirow{2}{*}{$\begin{array}{l}\text { Rel. activity } \\
(\%)\end{array}$} \\
\hline & & $\mathrm{Ca}(\mathrm{II})$ & $\operatorname{Mg}(\mathrm{II})$ & & \\
\hline-- & & -- & & 0.046 & 100 \\
\hline $\mathrm{CaCO}_{3}$ & & $10^{-4}$ & & 0.034 & 74 \\
\hline $\mathrm{CaCO}_{3}$ & $\mathrm{MgSO}_{4}$ & $10^{-4}$ & $510^{-4}$ & 0.036 & 78 \\
\hline $\mathrm{CaCO}_{3}$ & $\mathrm{MgSO}_{4}$ & $10^{-4}$ & $10^{-3}$ & 0.036 & 78 \\
\hline $\mathrm{CaCO}_{3}$ & $\mathrm{MgSO}_{4}$ & $10^{-4}$ & $510^{-3}$ & 0.039 & 85 \\
\hline $\mathrm{CaCO}_{3}$ & $\mathrm{MgSO}_{4}$ & $10^{-4}$ & $10^{-2}$ & 0.044 & 96 \\
\hline $\mathrm{CaCl}_{2}$ & $\mathrm{MgSO}_{4}$ & $10^{-3}$ & $10^{-2}$ & 0.037 & 80 \\
\hline $\mathrm{CaCl}_{2}$ & $\mathrm{MgSO}_{4}$ & $510^{-3}$ & $10^{-2}$ & 0.019 & 42 \\
\hline
\end{tabular}

a $0.309 \mathrm{M} \mathrm{D}$-glucose; $1.0 \mathrm{~g}$ Maxazyme GI-Immob.; $70.2{ }^{\circ} \mathrm{C} ; \mathrm{pH}=7.1$ $\mathrm{H}_{2} \mathrm{O}$.

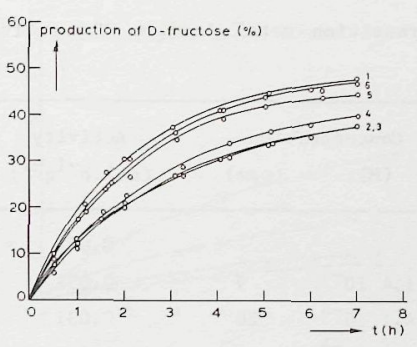

Fig. 7. The influence of $\mathrm{CaCO}_{3}$ on the activity of Maxazyme GI-Immob. $0.307 \mathrm{M}$ D-glucose, $1.0 \mathrm{~g}$ Maxazyme GI-Immob., $70.2{ }^{\circ} \mathrm{C}, \mathrm{pH}=$ $7.1, \mathrm{H}_{2} \mathrm{O}$. (2), blank; (2), $10^{-4} \mathrm{M} \mathrm{CaCO}_{3}$; (3), $10^{-4} \mathrm{M} \mathrm{CaCO}_{3}+$ $5.10^{-4} \mathrm{M} \mathrm{MgSO}_{4}$; (4), $10^{-4} \mathrm{M} \mathrm{CaCO}_{3}+10^{-3} \mathrm{M} \mathrm{MgSO}_{4}$; (5), $10^{-4} \mathrm{M}$ $\mathrm{CaCO}_{3}+5 \cdot 10^{-3} \mathrm{M} \mathrm{MgSO}_{4} ;(6), 10^{-4} \mathrm{M} \mathrm{CaCO}_{3}+10^{-2} \mathrm{M} \mathrm{MgSO}_{4}$.

The influences of some transition metal ions

During the hydrogenation reaction trace amounts of cations can be stripped off from the hydrogenation catalysts, which are generally not quantitatively reduced to metal $(0)$. For instance, the hydrogena-

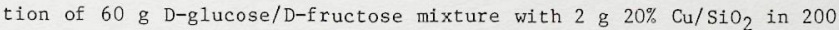
$\mathrm{ml} \mathrm{H}_{2} \mathrm{O}$ at $70{ }^{\circ} \mathrm{C}$ initially resulted in a concentration of $15 \mathrm{ppm}$ $\mathrm{Cu}(\mathrm{II})$ in solution, as determined by A.A.S. Upon further hydrogenation the amount of $\mathrm{Cu}$ (II) in solution was gradually reduced to 1-2 $\mathrm{ppm}$. In this respect, the influence of trace amounts $\mathrm{Cu}(\mathrm{II}), \mathrm{Ni}$ (II) and $\mathrm{Ru}($ III) on the activities of immobilized glucose isomerases has been investigated.

$\mathrm{Cu}($ II) and in particular $\mathrm{Ni}$ (II) cause a decrease in the activity of Maxazyme GI-Immob., whereas Ru(III) surprising1y enhances the enzyme activity (Table VIII, Figs. 8, 9 and 10). Optisweet 22 proves to be extremely sensitive to trace amounts of $\mathrm{Ni}$ (II) and especially $\mathrm{Cu}$ (II), whereas $\mathrm{Ru}$ (III) has no effect on the activity of Optisweet 22 (Table IX, Figs. 11 and 12). As shown above for $\mathrm{Ca}(\mathrm{II})$, the glucose isomerase in Maxazyme GI-Immob. is apparently much better protected against metal ion poisoning because it is present in whole cells entrapped in a gelatin-glutardialdehyde matrix. The following experiments showed that adsorption/complexation of $\mathrm{Cu}(\mathrm{II})$ at the gelatin- 
TABLE VIII

Influence of transition metal ions on the activity of Maxazyme GIImmob. ${ }^{a}$

\begin{tabular}{|c|c|c|c|c|}
\hline \multirow[t]{2}{*}{ Additive } & \multicolumn{2}{|c|}{ Concentration } & \multirow{2}{*}{$\begin{array}{c}\text { Activity } \\
\left(\operatorname{mol} \cdot \mathrm{h}^{-1} \mathrm{~g}^{-1}\right)\end{array}$} & \multirow{2}{*}{$\begin{array}{c}\text { Rel. activity } \\
(\%)\end{array}$} \\
\hline & (M) & (ppm) & & \\
\hline- & & & 0.046 & 100 \\
\hline $\mathrm{Cu}(\mathrm{II})$ & $1.410^{-4}$ & 9 & 0.031 & 67 \\
\hline $\mathrm{Cu}(\mathrm{II})$ & $4.110^{-4}$ & 26 & 0.031 & 67 \\
\hline $\mathrm{Cu}(\mathrm{II})$ & $14.510^{-4}$ & 93 & 0.023 & 50 \\
\hline $\mathrm{Ni}(\mathrm{II})$ & $1.210^{-4}$ & 7 & 0.030 & 65 \\
\hline $\mathrm{Ni}(\mathrm{II})$ & $12.110^{-4}$ & 71 & 0.017 & 37 \\
\hline $\mathrm{Ni}(I I)$ & $10010^{-4}$ & 587 & 0.009 & 20 \\
\hline$R u(I I I)$ & $0.810^{-4}$ & 8 & $0.053^{\circ}$ & 115 \\
\hline $\mathrm{Ru}(I I I)$ & $2.310^{-4}$ & 23 & 0.069 & 150 \\
\hline $\mathrm{Ru}(\mathrm{III})$ & $19.810^{-4}$ & 200 & 0.050 & 108 \\
\hline
\end{tabular}

a $0.617 \mathrm{M} \mathrm{D}$-glucose; $1.0 \mathrm{~g}$ Maxazyme GI-Immob.; $70.2{ }^{\circ} \mathrm{C} ; \mathrm{pH}=7.1$; $\mathrm{H}_{2} \mathrm{O}$.

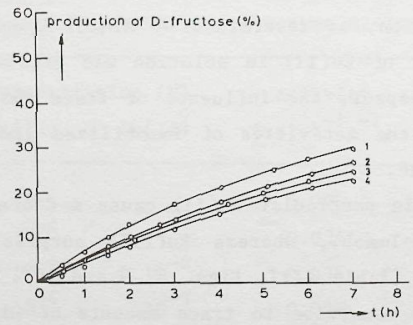

Fig. 8. The influence of $\mathrm{Cu}(\mathrm{II})$ on the activity of Maxazyme GI-Immob. $0.617 \mathrm{M} \mathrm{D}$-glucose, $1.0 \mathrm{~g}$ Maxazyme GI-Immob., $70.2{ }^{\circ} \mathrm{C}, \mathrm{pH}=$ $7.1, \mathrm{H}_{2} \mathrm{O}$. (1), blank; (2), $9 \mathrm{ppm} \mathrm{Cu(II);} \mathrm{(3),} 26 \mathrm{ppm} \mathrm{Cu(II);}$ (4), $93 \mathrm{ppm} \mathrm{Cu}(\mathrm{II})$.

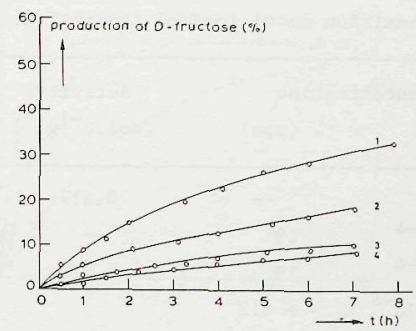

Fig. 9. The influence of $\mathrm{Ni}$ (II) on the activity of Maxazyme GI-Immob. $0.617 \mathrm{M}$ D-glucose, $1.0 \mathrm{~g}$ Maxazyme GI-Immob., $70.2{ }^{\circ} \mathrm{C}, \mathrm{pH}=$ $7.1, \mathrm{H}_{2} \mathrm{O}$. (1), blank; (2), $7 \mathrm{ppm} \mathrm{Ni(II);} \mathrm{(3),} 71 \mathrm{ppm} \mathrm{Ni(II);}$ (4), $587 \mathrm{ppm} \mathrm{Ni}(\mathrm{II})$

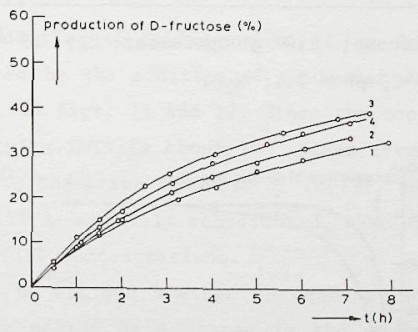

Fig. 10. The influence of $R u(I I I)$ on the activity of Maxazyme GIImmob

$0.617 \mathrm{M} \mathrm{D-g1ucose,} 1.0 \mathrm{~g}$ Maxazyme GI-Immob., $70.2{ }^{\circ} \mathrm{C}$, pH $=$ $7.1, \mathrm{H}_{2}$ O. (1), blank; (2), $8 \mathrm{ppm} \mathrm{Ru(III);} \mathrm{(3),} 23 \mathrm{ppm}$ $\mathrm{Ru}($ III); (4), $200 \mathrm{ppm} \operatorname{Ru}($ III).

glutardialdehyde matrix is responsible for this phenomenon: addition of $2.0 \mathrm{~g}$ gelatin-glutardialdehyde matrix (prepared according to the literature ${ }^{9}$ ) to an aqueous solution ( $50 \mathrm{ml}$ ) containing $60 \mathrm{ppm} \mathrm{Cu}$ (II) diminished the $\mathrm{Cu}(\mathrm{II})$ concentration to $30 \mathrm{ppm}$. Similar differences in metal ion inhibition has been observed by Kasumi et at. ${ }^{39}$ between 
TABLE IX

Influence of transition metal ions on the activity of optisweet $22^{\text {a }}$

\begin{tabular}{|c|c|c|c|c|}
\hline \multirow[t]{2}{*}{ Additive } & \multicolumn{2}{|c|}{ Concentration } & \multirow{2}{*}{$\begin{array}{c}\text { Activity } \\
\left(\mathrm{mol} \cdot \mathrm{h}^{-1} \mathrm{~g}^{-1}\right)\end{array}$} & \multirow{2}{*}{$\begin{array}{c}\text { Rel. activity } \\
(\%)\end{array}$} \\
\hline & (M) & $(\mathrm{ppm})$ & & \\
\hline-- & & - & 0.617 & 100 \\
\hline $\mathrm{Cu}(\mathrm{II})$ & $310^{-4}$ & 19 & -- & 0 \\
\hline $\mathrm{Cu}(\mathrm{II})$ & $310^{-4}$ & 19 & 0.268 & 43 \\
\hline + EDTA & $+310^{-4}$ & +112 & & \\
\hline-- & & & 0.617 & 100 \\
\hline $\mathrm{Ni}(I I)$ & $3.410^{-4}$ & 20 & 0.092 & 15 \\
\hline $\mathrm{Ni}(\mathrm{II})$ & $3.410^{-4}$ & 20 & 0.268 & 43 \\
\hline + EDTA & $+3.410^{-4}$ & +127 & & \\
\hline-- & & & $0.617^{\prime}$ & 100 \\
\hline $\mathrm{Ru}(\mathrm{III})$ & $2.510^{-4}$ & 25 & 0.569 & 92 \\
\hline
\end{tabular}

a $0.617 \mathrm{M} \mathrm{D-glucose} ; 1.0 \mathrm{~g}$ Optisweet $22 ; 10^{-2} \mathrm{M} \mathrm{Mg}(\mathrm{II}) ; 10^{-4} \mathrm{M}$ $\mathrm{Ca}(\mathrm{II}) ; 70.2{ }^{\circ} \mathrm{C} ; \mathrm{pH}=7.1 ; \mathrm{H}_{2} \mathrm{O}$.

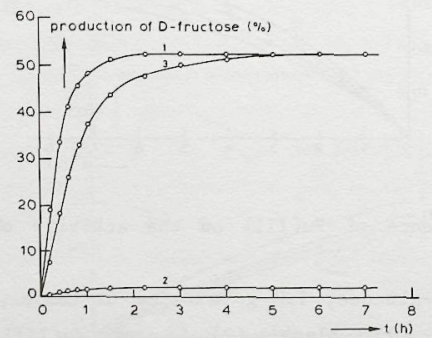

Fig. 11. The influence of $\mathrm{Cu}(\mathrm{II})$ on the activity of Optisweet 22 . $0.619 \mathrm{M} \mathrm{D}$-g1ucose, $1.0 \mathrm{~g}$ optisweet $22,10^{-2} \mathrm{M} \mathrm{Mg}(\mathrm{II}), 10^{-4} \mathrm{M}$ $\mathrm{Ca}(\mathrm{II}), 70.2^{\circ} \mathrm{C}, \mathrm{pH}=7.1, \mathrm{H}_{2} \mathrm{O}$.

(1), blank; (2), $19 \mathrm{ppm} \mathrm{Cu(II);} \mathrm{(3),} 19 \mathrm{ppm} \mathrm{Cu(II)} \mathrm{+} 112 \mathrm{ppm}$ EDTA.

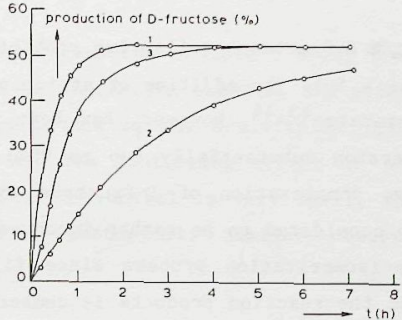

Fig. 12. The influence of $\mathrm{Ni}(\mathrm{II})$ on the activity of Optisweet 22. $0.617 \mathrm{M} \mathrm{D}-g$ lucose, $1.0 \mathrm{~g}$ optisweet $22,10^{-2} \mathrm{M} \mathrm{Mg}(\mathrm{II}), 10^{-4} \mathrm{M}$ $\mathrm{Ca}(\mathrm{II}), 70.2{ }^{\circ} \mathrm{C}, \mathrm{PH}=7.1, \mathrm{H}_{2} \mathrm{O}$.

(1) Blank; (2), $20 \mathrm{ppm} \mathrm{Ni(II);} \mathrm{(3),} 20 \mathrm{ppm} \mathrm{Ni(II)} \mathrm{+} 127 \mathrm{ppm}$ EDTA.

non-immobilized glucose isomerase and glucose isomerase immobilized in a chitosan matrix.

The strong inhibition of $\mathrm{Cu}$ (II) and $\mathrm{Ni}$ (II) on Optisweet 22 can be largely counteracted by the addition of equimolar amounts of EDTA as shown in Table IX and Figs. 11 and 12. Since the coordination of both $\mathrm{Cu}$ (II) and Ni(II) with EDTA is about $10^{10}$ times stronger than that of $\mathrm{Ca}(\mathrm{II})$ and $\mathrm{Mg}(\mathrm{II})^{40}$, the trace amounts of $\mathrm{Cu}(\mathrm{II})$ and $\mathrm{Ni}(\mathrm{II})$ present ( $15 \mathrm{ppm}$ ) are still selectively coordinated, even in the presence of relatively high $\mathrm{Mg}$ (II) concentrations.

It cannot yet be decided whether an exchange of cations at the active site of the enzyme or a change in the conformation, brought about by cation coordination near the active site of the enzyme, is responsible for a decrease in enzyme activity in the case of $\mathrm{Ca}$ (II), $\mathrm{Ni}(\mathrm{II})$ and $\mathrm{Cu}(\mathrm{II})$. The combination of cation exchange at the active center with a change in the conformation of the enzyme, adsorption/ complexation of cations on the carrier matrix, the rate of diffusion of cations and the possible strong coordination of substrate with the cation in the active center of the enzyme should also be taken in account. A full explanation of the influences of cations on the activity of immobilized glucose isomerase lies beyond the scope of this chapter. 
Borates as additive

The D-glucose $\rightleftharpoons$ D-fructose equilibrium prohibits D-glucose conversion of more than - 50\%. The addition of stoichiometric amounts of borates ${ }^{41,42}$ or germanates 43,44 , however, has been found to increase the D-glucose conversion substantially (up to $90 \%$ ). This phenomenon is due to selective complexation of $\mathrm{D}$-fructose with these anions. Such an approach is considered to be rather inconvenient for the combined hydrogenation-isomerization process since (i) the removal of these additives from the reaction products is cumbersome and ( $i$ ) the strong complexation of the hydrogenation products D-mannitol and D-glucitol with these anions would require more than stoichiometric amounts of such additives. On the other hand the selectivity of the formation of D-mannitol from $\mathrm{D}$-fructose by hydrogenation over $\mathrm{Cu} / \mathrm{SiO}_{2}$ is enhanced by adding catalytic amounts of borates to the reaction mixture 45,46 . Therefore, this effect of borate addition is of direct importance for an increased overall yield of. D-mannitol and has not the disadvantages as mentioned above. Furthermore, small amounts of borates as such and of borates in the presence of $\mathrm{Mg}$ (II) and $\mathrm{Ca}$ (II) have negligible effects on the activity of Maxazyme GI-Immob, as shown in Table $x$.

TABLE $\mathrm{X}$

Influence of borates on the activity of Maxazyme GI-Immob. ${ }^{2}$

\begin{tabular}{lccc}
\hline Additive & $\begin{array}{c}\text { Concentration } \\
(\mathrm{M})\end{array}$ & $\begin{array}{c}\text { Activity } \\
\left(\mathrm{mol} . \mathrm{h}^{-1} \mathrm{~g}^{-1}\right)\end{array}$ & $\begin{array}{c}\text { Rel. activity } \\
(\%)\end{array}$ \\
\hline- & -- & 0.046 & 100 \\
Borate & $510^{-4}$ & 0.046 & 100 \\
Borate & $10^{-3}$ & 0.046 & 100 \\
Borate & $210^{-3}$ & 0.046 & 100 \\
Borate & $510^{-3}$ & 0.046 & 100 \\
Borate & $810^{-3}$ & 0.046 & 100 \\
Borate & $310^{-2}$ & 0.031 & 67 \\
Borate $+\mathrm{Mg}$ (II) & $510^{-3}+10^{-2}$ & 0.063 & 137 \\
Borate $+\mathrm{Mg}$ (II) & $510^{-3}+10^{-2}$ & 0.043 & 94 \\
+ Ca(II) & $+10^{-4}$ & & \\
\hline
\end{tabular}

a $0.617 \mathrm{M} \mathrm{D}$-glucose; $1.0 \mathrm{~g}$ Maxazyme GI-Immob.; $70.2{ }^{\circ} \mathrm{C} ; \mathrm{pH}=7.1$, $\mathrm{H}_{2} \mathrm{O}$.
The influence of sugar alcohols

During the hydrogenation of invert sugar D-mannitol and D-glucitol are produced in increasing amounts. The effects of these alditols and two model compounds on the activity of Optisweet 22 are summarized in Table XI. The inhibiting effect of D-mannitol, 2-deoxy-Dglucose and 2-deoxy-D-glucitol is very small, whereas that of D-glucitol proves to be substantial. Similar observations were made by

TABLE XI

Influence of D-glucitol and D-mannitol on the activity of Optisweet $22^{\mathrm{a}}$.

\begin{tabular}{|c|c|c|c|c|}
\hline Additive & $\begin{array}{l}\text { Concentration } \\
\text { (M) }\end{array}$ & $\begin{array}{l}\text { Molar ratio } \\
\text { (polyol/D- } \\
\text { glucose) }\end{array}$ & $\begin{array}{c}\text { Activity } \\
\left(\operatorname{mol} \cdot \mathrm{h}^{-1} \mathrm{~g}^{-1}\right)\end{array}$ & $\begin{array}{c}\text { Rel. activity } \\
(\%)\end{array}$ \\
\hline-- & & & 0.617 & 100 \\
\hline D-Glucitol & 0.12 & 0.2 & 0.342 & 55 \\
\hline D-Glucitol & 0.31 & 0.5 & 0.284 & 46 \\
\hline D-Glucitol & 0.61 & 1 & 0.213 & 35 \\
\hline D-Glucitol & 1.20 & 2 & 0.163 & 26 \\
\hline-- & & & 0.617 & 100 \\
\hline D-Mannitol & 0.12 & 0.2 & 0.521 & 84 \\
\hline D-Mannitol & 0.31 & 0.5 & 0.521 & 84 \\
\hline D-Mannitol & 0.61 & 1 & 0.498 & 81 \\
\hline D-Mannitol & 1.20 & 2 & 0.475 & 77 \\
\hline $\begin{array}{l}\text { 2-Deoxy-D- } \\
\text { glucose }\end{array}$ & 0.12 & 0.2 & 0.613 & 99 \\
\hline $\begin{array}{r}\text { 2-Deoxy-D- } \\
\text { glucitol }\end{array}$ & 0.12 & 0.2 & 0.605 & 98 \\
\hline
\end{tabular}

a $0.617 \mathrm{M} \mathrm{D}$-glucose; $1.0 \mathrm{~g}$ Optisweet $22 ; 10^{-2} \mathrm{M} \mathrm{Mg}(\mathrm{II}) ; 10^{-4} \mathrm{M}$ $\mathrm{Ca}($ II $) ; 70.2{ }^{\circ} \mathrm{C} ; \mathrm{pH}=7.1 ; \mathrm{H}_{2} \mathrm{O}$. 


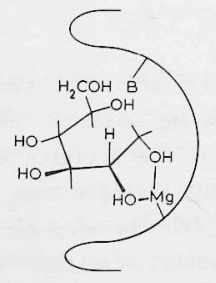

Fig. 13. D-Glucitol can mimic the D-glucose-enzyme complex.

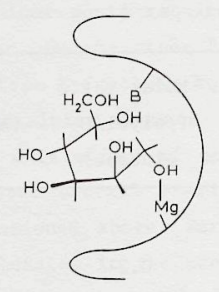

Fig. 14. D-Mannitol cannot mimic the D-glucose-enzyme complex.

Scallet et al.17 for the effects of sugars and sugar alcohols on the isomerase activity of Actinoplanes missouriensis. Apparently, D-glucitol may mimic a D-glucose (or D-fructose) molecule quite effectively: both size and $\mathrm{Mg}$ (II) coordination fulfil the conditions of the active site of the enzyme species. D-Glucitol in a pseudo-cyclic bent conformation indeed closely resembles the geometry of D-glucose, as depicted in Fig. 13. On the contrary, D-mannitol, 2-deoxy-D-glucose and 2-deoxy-D-glucitol are not able to mimic the D-glucose geometry. For D-mannitol the $2-\mathrm{OH}$ is in the wrong ('axial') position (Fig. 14), which is consistent with the fact that glucose isomerase is unable to isomerize D-mannose and D-arabinose (Table I). For 2-deoxy-D-glucose and 2-deoxy-D-glucitol the absence of the 'equatorial' 2-OH prohibits bidentate coordination with $\mathrm{Mg}$ (II), which is thought to be essential for the formation of the cis-enediol intermediate. As expected, these compounds show no decrease in the activity of Optisweet 22. In this respect, it may be noted that possible extraction of $\mathrm{Mg}$ (II) from the active site of the enzyme by D-glucitol may also play a role, since the coordination of $\mathrm{D}$-glucitol with $\mathrm{Mg}$ (II) is stronger than that of D-mannitol and of D-glucose ${ }^{47}$. It may be noted that the ultimate concentration under practical conditions ( $1.2 \mathrm{M}$ invert sugar) will be 0.5 M D-glucitol and 0.7 M D-mannitol.

Consequently one has to take into account a decrease of enzymatic activity by a factor 3 due to product formation during the simultaneous hydrogenation reaction.

The influence of inmobilized glucose isomerase on the hydrogenation catalysts

It was found that the presence of Maxazyme GI-Immob. and Sweetzyme $Q$ resulted in a decrease of the activity of the hydrogenation catalysts platinum on carbon and copper on silica ${ }^{48}$. Probably, this is due to co-adsorption of small amounts of mobile fragments that leach out of the immobilized glucose isomerase onto the hydrogenation catalyst. The poisoning of the hydrogenation catalyst observed by Optisweet 22 is less serious, as would be expected from the fact that it consists of a purified enzyme system covalently bound to an inorganic support $\left(\mathrm{SiO}_{2}\right)$.

\section{Conclusions}

The immobilized glucose isomerase either in its entrapped cell environment (Maxazyme GI-Immob., glucose isomerase in whole cells entrapped in a gelatin-glutardialdehyde matrix) or in its purified form (Optisweet 22, isolated glucose isomerase, covalently attached to $\mathrm{SiO}_{2}$ ) may be conveniently applied, with partial conservation of its activity, under hydrogenation conditions $\left(70{ }^{\circ} \mathrm{C}\right.$, up to $75 \mathrm{~kg} / \mathrm{cm}^{2}$ $\mathrm{H}_{2}$-pressure). The D-glucose/D-fructose equilibrium constant is independent of the total concentration between 0.2 and $2.2 \mathrm{M}$. Small amounts of $\mathrm{CaCO}_{3}$ and $\mathrm{MgSO}_{4}$ should be present in order to maintain sufficient enzyme activity (i.e. $\mathrm{pH}-7$ and $\mathrm{Mg}$ (II) source for the enzyme, respectively). Maxazyme GI-Immob. and Sweetzyme $Q$ result in a higher degree of poisoning of the hydrogenation cataiyst than Optisweet 22. On the other hand, traces of $\mathrm{Cu}$ (II) from the hydrogenation catalyst seriously poison optisweet 22 , which can be counteracted by the addition of a trace quantity of EDTA. Of the hydrogenation pro- 
ducts D-mannitol and D-glucitol, the latter has some enzyme inhibiting effect. This is explained by the ability of D-glucitol to mimic the D-glucose geometry in the active site of glucose isomerase.

\section{$\underline{\text { References }}$}

1. M. Makkee, A.P.G. Kieboom, H. van Bekkum, and J.A. Roels, J. Chem. Soc., Chem. Commun. 1980, 930.

2. M. Makkee, A.P.G. Kieboom, H. van Bekkum, and J.A. Roels, Abstracts of Papers, 29th IUPAC Congress, Cologne, (1983) 434.

3. G. Danno, Agric. Biol. Chem. 34 (1970) 1805

4. Y. Takasaki, Y. Kosugi, and A. Kanbayashi, Agric. Biol. Chem. 33 (1969) 1527.

5. R.O. Marsha11 and E.R. Kooi, Science 125 (1957) 648.

6. M. Natake, Agric. Biol. Chem. 32 (1968) 303.

7. C. Bucke, Enzyme and Fermentation Biotechrology, A. Wiseman, Ed., Vo1. I, Ellis Horwood Ltd., Chichester, England (1977) 147

C. Bucke, Microbial Enzymes and Biotechnology, W.M. Fogarty, Ed., Applied Science Publishers, London, England (1983) 93.

8. W.P. Chen, Proc. Biochem. 15 (1980) 30.

9. R. van Tilburg (1983), Ph.D. Thesis, Engineering Aspects of Biocatalysts in Industrial Starch Conversion Technology (Delft University of Technology, The Netherlands).

10. N. Suekane, M. Tamura, and C. Tomimura, Agric. Biol. Chem. 42 (1978) 909.

11. K. Yamanaka, Biochem. Biophys. Acta 151 (1968) 670 .

12. R.A. Houge-Angeletti, J. Biol. Chem. 250 (1975) 7814

13. G. Danno, Agric. Biol. Chem. 34 (1970) 1795.

14. T. Kasumi, K. Hayashi, and N. Tsumura, Agric. Biol. Chem. 45 (1981) 1097

15. C.S. Gong, L.F. Chen, and G. Tsao, Biotechnol. Bioeng. 22 (1980) 833

16. K. Schray and A.S. Mildvan, J. Biol. Chem. 247 (1972) 2034.

17. B.L. Scallet, K.K. Shieh, I. Ehrental, and L. Slapshak, Starch 26 (1974) 405.

18. N. Tsumura and T. Sato, Agric. Biol. Chem. 29 (1965) 1123.

19. S. Yoshimura, G. Danno, and M. Natake, Agric. Biol. Chem. 30 (1966) 1015.
20. S. Sanchez and K.L. Smiley, Appl. Microbiol, 29 (1975) 745.

21. M.S. Feather, V. Deshpande, and M.J. Lybyer, Biochem. Biophys. Res. Commun. 38 (1970) 859.

22. K. Bock, M. Meldal, B. Meyer, and L. Wiebe, Acta Chem. Scand. B 37 (1983) 101

23. Y. Takasaki, O. Tanabe, and T. Shuntaro, Agric. Biol. Chem. 28 (1964) 605.

24. K. Schray and I.A. Rose, Biochemistry 10 (1971) 1058.

25. K.R. Hanson and I.A. Rose, Acc. Chem. Res. 8 (1975) 1.

26. Chapter 6 .

27. E. Lász1ó, A. Hoschke, and J. Holló, Starch 30 (1978) 242;

A. Hoschke, K. Balogh, E. László, and J. Holló, Starch 36 (1984) 26.

28. A.S. Mildvan, Bio-Inorganic Chemistry, R.F. Gould, Ed., American Chemical Society, Washington D.C. (1971) 404.

29. Gist Brocades N.V., Datasheet Maxazyme GI-Immob., Mgi-02-01/83.03.En.05.

30. Novo Industri A.S., Datasheet Sweetzyne Q, B 174d-GB 2000, Aug. 1981.

31. Miles Kali-Chemie, Advances in the Enzymatic Processing of the Starch Industry.

32. J.V. Hupkes and R. van Tilburg, Starch 28 (1976) 356.

33. L. Zittan, P.B. Poulsen, and S.H. Hemmingsen, Starch 27 (1975) 236.

34. Novo Industri A.S., Datasheet Sweetzyme Q, IB 175c-GB, Aug. 1981.

35. Brit. Pat. (1975) $1,399,408$.

36. Brit. Pat. (1976) 1,455,993.

37. Chapter 8.

38. M.W. Kearsley, S.H. Satti, and I. Tregaskis, Starch 32 (1980) 169.

39. T. Kasumi, K. Hayashi, N. Tsumura, and M. Tsuji, Agric. Biol. Chem. 41 (1977) 1865.

40. A.E. Martell and R.M. Smith, Critical Stability Constants, Vol. I, Amino Acids, Plenum Press, New York (1974) 204.

41. U.S. Pat. (1972) 3,689,362.

42. G. Tegge, Starch 31 (1979) 409.

43. H. Pelmore and P.J. Somers, Enzyme Microb. Technol. 4 (1982) 390.

44. S.A. Barker, H. Pelmore, and P.J. Somers, Enzyme Microb. Technol. 5 (1983) 121. 
45. Eur. Pat. (1980) 6313.

46. Chapter 3.

47. A.P.G. Kieboom, H.M.A. Buurmans, L.K. van Leeuwen, and H.J. van Benschop, Rec1. Trav. Chim. Pays-Bas 98 (1979) 393.

48. Chapter 7.

\section{MECBANISM OF THE ENZYMATIC ISOMERIZATION OF D-GLUCOSE AND D-FRUCTOSE*}

\section{Introduction}

Immobilized glucose isomerase (D-xylose ketol isomerase; E.C. 5.3.1.5) is applied on an industrial scale for the isomerization of D-glucose syrups into D-fructose containing syrups ${ }^{1-3}$. The D-glucose/Dfructose interconversion is thought to take place via a cio-enediol intermediate coordinated to a metal ion (Mg(II) or $\mathrm{Co}(\mathrm{II})$ ) of the enzyme ${ }^{4}$ (Fig. 1)

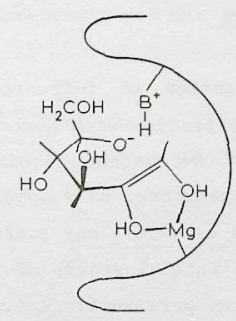

Fig. 1. Proposed cis-enediol intermediate ${ }^{4}$.

It has been assumed that a basic center of the enzyme is involved in the intramolecular hydrogen transfer from $\mathrm{C}-2$ of $\mathrm{D}-\mathrm{glucose}$ towards $\mathrm{C}-1$ of D-fructose and vice versa ${ }^{4,5}$. Experimentally, no exchange between the transferred hydrogen and water has been found ${ }^{5,6}$. The orientation of the side chain of the eis-enediol enzyme complex will induce, using the

\footnotetext{
Accepted for publication in 'Recl. Trav. Chim. Pays-Bas'.
} 
principle of least molecular motion, $\alpha-D$-glucopyranose formation by attack of $0-5$ at $\mathrm{C}-1$. This indeed has been recently verified by NMR spectroscopy ${ }^{5}$ and is in accord with earlier results for the D-xylose/Dxylulose interconversion by the same type of enzyme ${ }^{6}$.

With respect to the ketose reactant of the enzymatic isomerization, it is generally assumed that the $\beta$-furanose form of D-fructose is the reactive substrate ${ }^{5,7}$. Inspection of molecular models, however, shows that conversion of the cis-enediol intermediate (Fig. 1) into B-D-fructofuranose requires a substantial geometric reorientation. According to the principle of least molecular motion, $\alpha$-D-fructofuranose is expected to be the reactive species.

This consideration and the fact that the ${ }^{13} \mathrm{C}$ NMR data presented by Bock et al. ${ }^{5}$ with respect to the determination of the reactive D-fructose lie close to the experimental error, led us to reinvestigate the nature of the reactive species for the enzymatic D-glucose-D-fructose interconversion.

\section{Results and discussion}

The fast mutarotation of D-fructose at the optimum temperature $\left(65^{\circ} \mathrm{C}\right)$ for the isomerization with glucose isomerase and the absence of anomeric hydrogens of $\mathrm{D}$-fructose require the use of ${ }^{13} \mathrm{C} N \mathrm{NR}$ at short reaction times. We, therefore, have applied ${ }^{13} \mathrm{C}$ NMR together with $1-{ }^{13} \mathrm{C}-$ D-glucose in order to establish any preferential anomeric specificity of the enzyme during the initial stages of the isomerization reaction. Four transients per spectrum were sufficient. As the enzyme insoluble glucose isomerase (Optisweet P) from Miles Kali-Chemie was used. A selection of the data obtained from $115^{13} \mathrm{C}$ NMR spectra, recorded at intervals of 33 seconds of the enzymatic isomerization of mutarotated $1-{ }^{13} \mathrm{C}-\mathrm{D}-\mathrm{g}$ lucose are shown in Fig. 2 and in Table I (with $G p=$ glucopyranose, $F p=$ fructopyranose, $\mathrm{Ff}=$ fructofuranose).

First, there is a steep decrease of the $\alpha / \beta$ ratio of $D$-glucopyranose at short reaction times, i.e. from $0.61 \pm 0.02$ at $t=0$ to $0.45 \pm 0.01$ at $t=3.3 \mathrm{~min}$ (Fig. 3). This result proves that $\alpha-D-g 1$ ucopyranose is the reactive species, which is in accordance with the literature ${ }^{4-6}$.

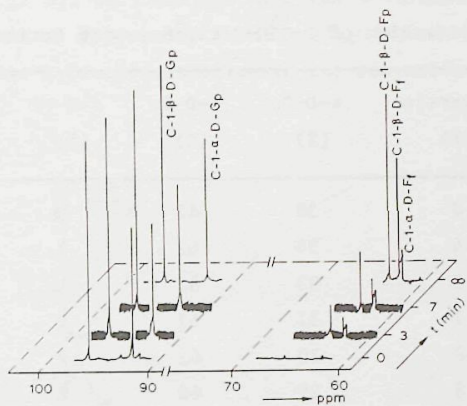

Fig. 2. Four of the $115^{13} \mathrm{C}$ NMR spectra taken during the enzymatic isomerization of mutarotated $1-{ }^{13} \mathrm{C}-\mathrm{D}-\mathrm{g}$ lucose towards a mixture of $1-{ }^{13} \mathrm{C}-\mathrm{D}-\mathrm{g} 1 \mathrm{ucose}$ and $1-{ }^{13} \mathrm{C}-\mathrm{D}-\mathrm{fructose}$ at different reaction times. Conditions: $\mathrm{D}_{2} \mathrm{O}-\mathrm{H}_{2} \mathrm{O}(1: 1), \mathrm{pH} \sim 7 ; 66{ }^{\circ} \mathrm{C}$; glucose isomerase (Optisweet P), $12.5 \mathrm{~g} / 1 ;\left[1-{ }^{13} \mathrm{C}-\mathrm{D}-\mathrm{g} 1\right.$ ucose $]=0.14 \mathrm{M}$ at $t=0$ (reaction times corrected for 5 min warming-up from $0-66^{\circ} \mathrm{C}$ ).

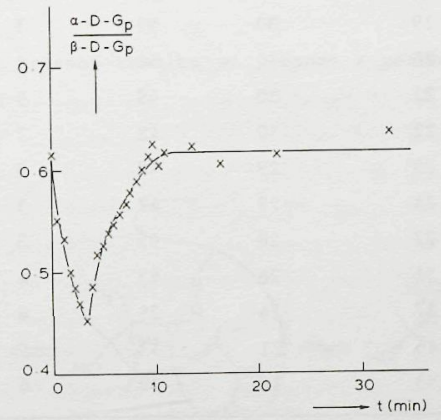

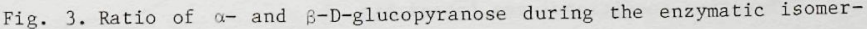
ization of $1{ }^{13} \mathrm{C}-\mathrm{D}-\mathrm{gl}$ ucose. Reaction conditions: see legend Fig. 
TABLE I

Enzymatic conversion of $1-{ }^{13} \mathrm{C}-\mathrm{D}-\mathrm{g}$ lucose with Optisweet $\mathrm{P}^{\mathrm{a}, \mathrm{b}}$.

\begin{tabular}{|c|c|c|c|c|c|c|}
\hline $\begin{array}{l}\text { Time } \\
(\min )\end{array}$ & $\begin{array}{c}\text { Conversion } \\
(\%)\end{array}$ & $\begin{array}{c}\alpha-D-G p \\
(\%)\end{array}$ & $\begin{array}{c}\beta-D-G P \\
(\%)\end{array}$ & $\begin{array}{c}\alpha-D-F f \\
(\%)\end{array}$ & $\begin{array}{c}\beta-D-F f \\
(\%)\end{array}$ & $\begin{array}{c}B-D-F P \\
(\%)\end{array}$ \\
\hline 0.00 & 0 & 38 & 62 & 0 & 0 & 0 \\
\hline 0.55 & 4 & 34 & 62 & 1 & 1 & 2 \\
\hline 1.10 & 5 & 33 & 62 & 1 & 1 & 3 \\
\hline 1.65 & 7 & 31 & 62 & 2 & 2 & 3 \\
\hline 2.20 & 8 & 30 & 62 & 2 & 2 & 4 \\
\hline 2.75 & 9 & 29 & 62 & 2 & 2 & 5 \\
\hline 3.30 & 10 & 28 & 62 & 2 & 3 & 5 \\
\hline 3.85 & 11 & 29 & 60 & 2 & 3 & 6 \\
\hline 4.40 & 12 & 30 & 58 & 2 & 4 & 6 \\
\hline 4.95 & 13 & 30 & 57 & 2 & 4 & 7 \\
\hline 5.50 & 14 & 30 & 56 & 2 & 4 & 8 \\
\hline 6.05 & 15 & 30 & 55 & 2 & 5 & 8 \\
\hline 6.60 & 16 & 30 & 54 & 3 & 5 & 8 \\
\hline 7.15 & 17 & 30 & 53 & 3 & 5 & 9 \\
\hline 7.70 & 18 & 30 & 52 & 3 & 5 & 10 \\
\hline 8.25 & 19 & 30 & 51 & 3 & 6 & 10 \\
\hline 8.80 & 20 & 30 & 50 & 3 & 7 & 10 \\
\hline 9.35 & 21 & 30 & 49 & 3 & 7 & 11 \\
\hline 9.90 & 22 & 30 & 48 & 3 & 7 & 12 \\
\hline 10.45 & 23 & 29 & 48 & 3 & 8 & I2 \\
\hline 11.00 & 24 & 29 & 47 & 3 & 8 & 13 \\
\hline 13.75 & 27 & 28 & 45 & 3 & 9 & 15 \\
\hline 16.50 & 31 & 26 & 43 & 4 & 10 & 17 \\
\hline 22.00 & 37 & 24 & 39 & 4 & 12 & 21 \\
\hline 33.00 & 46 & 21 & 33 & 5 & 17 & 24 \\
\hline$\infty$ & 53 & 18 & 29 & 6 & 18 & 30 \\
\hline
\end{tabular}

a Reaction conditions: see legend Fig. 2 .

b Percentages \pm 0.5 .

Secondly, mutual comparison of the peak heights of the $\alpha$ - and $B$-fructofuranoses at these short reaction times ( 5 measurements) indicate an

$\alpha / \beta$ ratio of about 1 , which then gradually decreases to the equilibrium value of 0.35 (Fig. 4). We conclude that the $\alpha$-furanose form (and not the $\beta$-furanose form as reported ${ }^{5}$ ) is initially formed and consequently is also the reactive $\mathrm{D}$-fructose species in the enzymatic isomerization.

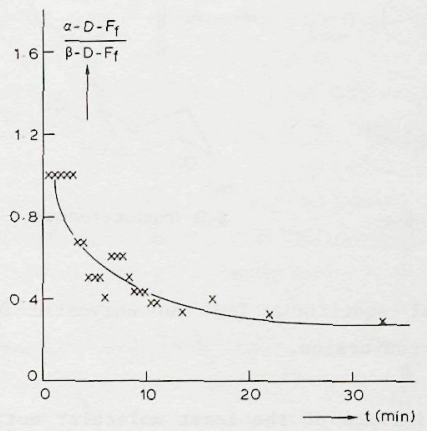

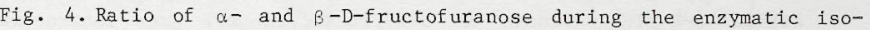
merization of ${ }^{1-13} \mathrm{C}-\mathrm{D}-\mathrm{glucose}$. Reaction conditions: see legend Fig. 2.

On the basis of the present results we propose a mechanism as illustrated in Figs. 5 and 6.

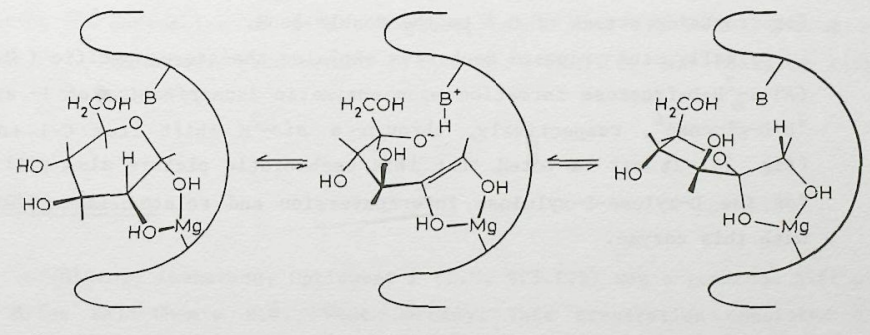

$\alpha-D$-glucopyranose

cis-enediol intermediate

$\alpha-D$-fructofuranose

Fig. 5. Mechanism of the interconversion of D-glucose and D-fructose by the enzyme glucose isomerase (E.C. 5.3.1.5). 


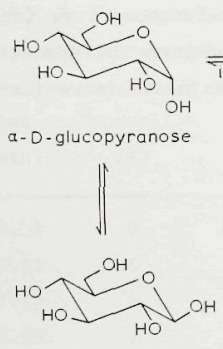

$\beta$ - D-glucopyranose

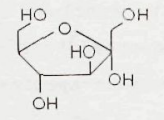

$a-D$-fructofuranose

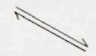

a-D-fructo

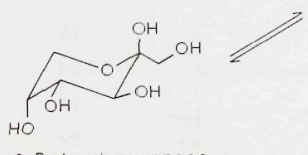

$\beta$ - D-fructopyranose

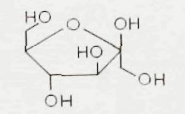

B-D-fructofuranose

Fig. 6. Actual equilibria for the enzymatic D-glucose and D-fructose interconversion.

Using the principle of the least molecular motion, ring closure by $0-5$ of the cis-enediol intermediate, accompanied by proton attack, gives either $\alpha$-D-glucopyranose or $\alpha-D$-fructofuranose. This interconversion requires almost no conformational change of the pseudo-cyclic enediol since the $0-5$ is favourably situated for backside attack of the $\mathrm{C}=\mathrm{C}$ bond on both $\mathrm{C}-1$ and $\mathrm{C}-2$. In this respect it may be noted that an $\alpha-\mathrm{D}-\mathrm{g} 1$ ucopyranose- $\beta-D-f$ ructofuranose interconversion would require a substantial reorientation of the $\mathrm{C}_{4}$ chain of the enediol intermediate, i.e. at least a rotation of $180^{\circ}$ around $\mathrm{C}-2-\mathrm{C}-3$ together with both a forward and backward rotation of $120^{\circ}$ around $\mathrm{C}-3-\mathrm{C}-4$. This to meet the required geometry for frontside attack of $0-5$ to the double bond.

Finally, the proposed mechanism explains the stereospecific (S) - and (R) $-1-{ }^{2} \mathrm{H}-\mathrm{D}-\mathrm{fructose}$ formation upon enzymatic isomerization of $1-$ and 2${ }^{2} \mathrm{H}-\mathrm{D}-\mathrm{glucose} \mathrm{C}^{4}$, respectively, through a $\mathrm{cis}^{2} \mathrm{H}$ shift from $\mathrm{C}-1$ to $\mathrm{C}-2$ (Fig. 7). It may be noted that this mechanistic picture also will hold for the D-xylose-D-xylulose interconversion and related isomerizations with this enzyme.
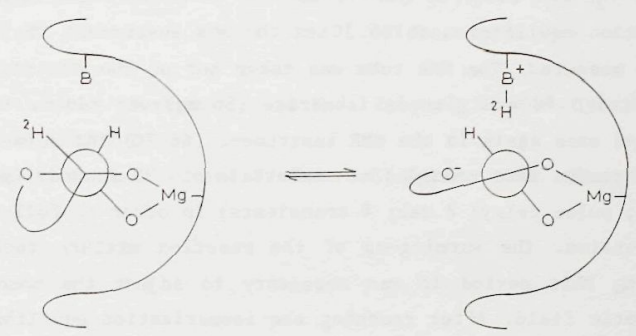

$a-D-G_{p}$
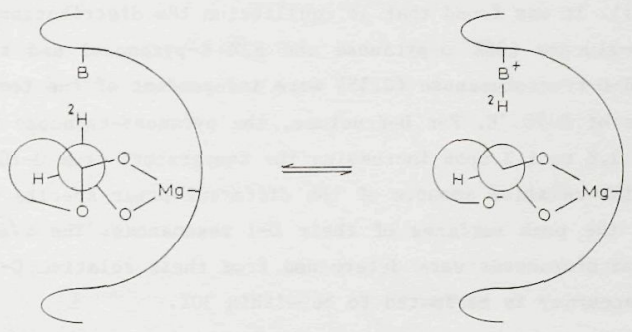

$\alpha-D-F_{f}$

Fig. 7. Mechanistic picture of the enzymatic stereoselective interconversion of $2-{ }^{2} \mathrm{H}-\alpha-\mathrm{D}-\mathrm{g} 1$ ucopyranose and $(R)-1-{ }^{2} \mathrm{H}-\alpha-\mathrm{D}-$ fructofuranose: concomitant frontside H-transfer and backside ring closure.

\section{Experimental}

Glucose isomerase, Optisweet P (E.C. 5.3.1.5) was a generous gift of Miles Kalí-Chemie K.G., West Germany. This preparation consisted of dried insoluble whole cells, containing glucose isomerase activity. $1-{ }^{13} \mathrm{C}-\mathrm{D}-\mathrm{Glucose}$, containing $99 \%{ }^{13} \mathrm{C}$, was obtained from C.E.A., France. The ${ }^{13} \mathrm{C}$ NMR experiments were carried out on a Nicolet NT-200 WB spectrometer, operated at $50.31 \mathrm{MHz} .1-{ }^{13} \mathrm{C}-\mathrm{D}-\mathrm{Glucose}(0.10 \mathrm{~g})$ was dissolved in 
$4 \mathrm{ml} \mathrm{D}_{2} \mathrm{O}-\mathrm{H}_{2} \mathrm{O}(1: 1)$ at $\mathrm{pH}-7$ in a $10 \mathrm{~mm}$ tube. After reaching the mutarotation equilibrium at $66{ }^{\circ} \mathrm{C}$ in the NMR instrument the ${ }^{13} \mathrm{C}$ NMR signals were measured. The NMR tube was taken out of the NMR instrument, cooled down to $0{ }^{\circ} \mathrm{C}$ and g1ucose isomerase $(50 \mathrm{mg})$ was added. The MMR tube was placed once again in the NMR instrument $\left(66^{\circ} \mathrm{C}\right)$ and subsequently $115^{13} \mathrm{C}$ NMR spectra were recorded at intervals of 33 seconds (pulse width: 20 usec; pulse delay: $8 \mathrm{sec} ; 4$ transients) in order to follow the enzymatic conversion. The warming-up of the reaction mixture took about $5 \mathrm{~min}$. During this period it was necessary to adjust the homogeneity of the magnetic field. After reaching the isomerization equilibrium the enzyme was removed by centrifugation and thereupon the anomeric distribution of mutarotated D-glucose and D-fructose determined as a function of temperature $\left(0.10 \mathrm{~g} 1-{ }^{13} \mathrm{C}-\mathrm{D}-\mathrm{g} 1 \mathrm{ucose} / 1-{ }^{13} \mathrm{C}\right.$ - D-fructose mixture in $4 \mathrm{ml} \mathrm{D}_{2} \mathrm{O}-\mathrm{H}_{2} \mathrm{O}$ $(1: 1))$. It was found that at equilibrium the distribution of the anomers of D-glucose ( $38 \% \quad \alpha$-pyranose and $62 \% \quad \beta$-pyranose) and the ratio of $\alpha$ and $\beta-D-f$ ructofuranose $(0.35)$ were independent of the temperature in the range of $0-70{ }^{\circ} \mathrm{C}$. For $\mathrm{D}$-fructose, the pyranose-furanose ratio decreased from 2.8 to 1.2 upon increasing the temperature from $0-70{ }^{\circ} \mathrm{C}$.

The relative amounts of the different sugar species were determined from the peak surfaces of their $c-1$ resonances. The $\alpha / \beta$ ratios of the D-fructofuranoses were determined from their relative $\mathrm{C}-1$ peak heights. The accuracy is estimated to be within $30 \%$.

\section{Acknowledgements}

Dr. J.A. Peters is acknowledged for recording the ${ }^{13} \mathrm{C}$ NMR spectra, Dr. G. Richter of Miles Kali-Chemie, Hannover, for providing the enzyme, and Dr. J.G. Batelaan of AKZO, Arnhem, for valuable discussions.

\section{$\underline{\text { References }}$}

1. United States Department of Agriculture, Sugar and Sweetener Outlook and Situation, (1981), Document No. 55RV6N2.

2. C. Bucke, Enzyme and Fermentation Biotechnology, A. Wiseman, Ed. Vol. I, Ellis Horwood Ltd., Chichester, England (1977) 147.

3. C. Bucke, Microbial Enzymes and Biotechnology, W.M. Fogarty, Ed. Applied Science Publishers, London, England (1983) 93.
4. K.R. Hanson and I.A. Rose, Acc. Chem. Res. 8 (1975) 1.

5. K. Bock, M. Meldal, B. Meyer, and L. Wiebe, Acta Chem. Scand. B 37 (1983) 101.

6. M.S. Feather, V. Deshpande, and M.J. Lybyer, Biochem. Biophys. Res. Commun. 38 (1970) 859.

7. Y. Takasaki, O. Tanabe, and T. Shuntaro, Agric. Biol. Chem. 28 (1964) 605. 
7. COMBINED ACTION OF ENZYME AND METAL CATALYST, APPLIED TO THE PREPARATION OF D-MANNITOL*

\section{Introduction}

Simultaneous action of a bio- and a chemo-catalyst is an attractive possibility for several catalytic processes in solution. For example, a starting compound is brought into equilibrium with a specific enzyme with an intermediate compound that is concomitantly and irreversibly transformed by the chemo-catalyst into the final product. Some problems to be faced with such a combined catalytic system are the narrow condition range of the enzyme, the preferential conversion of the intermediate compound by the chemo-catalyst, and the possible mutual poisoning of the two different catalysts.

As the first example of this approach we reported on the combined use of glucose isomerase and platinum in the preparation of the sugar substitute D-mannitol from D-glucose/D-fructose mixtures (e.g. invert sugar or isoglucose), leading to a D-mannitol yield of $46 \% 1,2$. Soon afterwards, Ruddlesden et at. ${ }^{3}$ applied glucose isomerase together with ruthenium loaded zeolite $Y$ in a similar approach in order to protect the hydrogenation catalyst against poisoning by the enzyme. The zeolite pores were thought to be inaccessible to inhibiting species. Starting from D-glucose a $29 \%$ yield of D-mannitol was realized with this system.

Another interesting approach, based on the combi-process procedure, involves the simultaneous enzymatic ( $\alpha$ - and $\beta$-amylase) hydrolysis and the catalytic (Raney-Nickel) hydrogenation of maize starch as reported by Kearsly et at. ${ }^{4}$. Their main goal was to bring about a faster and more complete enzynatic hydrolysis of starch upon withdrawal of D-glucose from the equilibrium by catalytic hydrogenation. Their combined hydroly-

\footnotetext{
* Accepted for publication in 'Carbohydrate Research'.
} 
sis-hydrogenation process was found to suffer from inhibition of the enzyme by the nickel catalyst.

The present chapter describes our further investigations towards the development of an improved combi production method for D-mannitol. Apart from its nice sweet taste and non-carious properties, D-mannitol is used in 'sugar free' chewing gums and pharmaceutical preparations due to its non-hygroscopicity property. Up to now, D-mannitol is commercially obtained in yields of less than $30 \%$ by the catalytic hydrogenation of D-glucose/D-fructose mixtures. The combination of either base- or molybdic acid-catalyzed isomerization of D-glucose and hydrogenation has been proposed as possible alternative chemical combi procedures. These, and possible other alternative preparation methods of $D$-mannitol have been reviewed by us in detail elsewhere ${ }^{5}$. Our combi-process is based on the enzymatic interconversion of the starting components D-glucose and D-fructose with concomitant and preferential hydrogenation of D-fructose, as depicted in Fig. ..

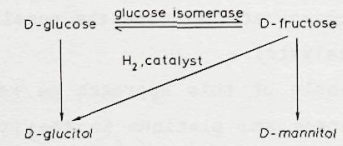

Fig. 1. Combi-process: simultaneous enzymatic isomerization and metal catalyzed hydrogenation of D-glucose/D-fructose mixtures.

Optimal D-mannitol formation in such an approach requires:

(i) preferential hydrogenation of D-fructose with respect to D-glucose;

(ii) selectivity towards D-mannitol for the D-fructose hydrogenation;

(iii) relatively fast $\mathrm{D}$-glucose $\rightleftharpoons \mathrm{D}$-fructose interconversion in order to maintain the $D$-fructose concentration at a maximum;

(iv) minimum interference of the two catalytic species, including their different demands for sufficient activity.

The requirements ( $i$ ) and ( $i$ ) were found to be best fulfilled with copper on silica as the hydrogenation catalyst ${ }^{6}$, showing an initial selectivity of 0.9 for the hydrogenation of D-fructose in a $1: 1$ D-glu-
cose/D-fructose mixture together with preferential (67-85\%) D-mannitol formation in the D-fructose hydrogenation. From the other catalysts investigated, platinum, ruthenium, osmium and iridium on carbon showed reasonable initial selectivities (0.8-0.9) for the preferential hydrogenation of $D$-fructose in the presence of D-glucose but showed lower values $(0.45-0.55)$ for the selective formation of $D$-mannitol in the D-fructose hydrogenation. For comparison, these catalysts have been included too in the present investigation. The hydrogenation conditions are largely determined by the narrow condition range of the glucose isomerase species $\left(50-70{ }^{\circ} \mathrm{C}, \mathrm{pH}=6 \cdot 5-8 \cdot 0\right)^{7}$. These moderate temperatures, however, restrict the hydrogenation rates. To meet the requirements (iii) and (iv) the enzyme glucose isomerase was used in an immobilized form. This possibly allows a simple separation of the enzyme from the reaction mixture and prevents serious interaction of the two catalyst systems. In this respect, we have investigated the behaviour of three commercially available immobilized glucose isomerases in combination with five different hydrogenation catalysts. Hydrogenations have been performed in aqueous solution in the presence of small amounts of $\mathrm{MgSO}_{4}$ (as enzyme stabilizing agent) and $\mathrm{CaCO}_{3}$ (as buffering agent) at $60-70{ }^{\circ} \mathrm{C}, \mathrm{pH}$ of $7.0-8.0$ and a hydrogen pressure of $20-50 \mathrm{~kg} / \mathrm{cm}^{2}$. As established before, immobilized glucose isomerase functions quite well under these high pressure conditions; there was only some decrease of enzyme activity due to the formation of D-mannitol and D-glucitol, which compete with D-glucose for the active site of the enzyme ${ }^{7}$.

\section{Experimental}

Materials

D-Glucose, D-fructose, calcium carbonate and sodium tetraborate were supplied by Merck. Magnesium sulfate, magnesium hydrogen phosphate and ethylenediaminetetraacetic acid were obtained from Baker. The catalysts $5 \%$ ruthenium and $5 \%$ platinum on carbon were obtained from Drijfhout Amsterdam. The preparations of $10 \%$ iridium on carbon, $5 \%$ osmium on carbon and $20 \%$ copper on silica are described elsewhere ${ }^{6}$. All the above mentioned catalysts were used without prior treatment. Maxazyme GIImmob., Sweetzyme $Q$ and Optisweet 22 were gifts of Gist Brocades N.V., Novo Industri A.S. and Miles Kali-Chemi K.G., respectively. Data of the 
enzyme preparations are given elsewhere ${ }^{7}$.

\section{Apparatus}

The simultaneous enzymatic isomerization and catalytic hydrogenation experiments were carried out in a $450 \mathrm{ml}$ Hastelloy B autoclave model 4562, manufactured by Parr. The autoclave was equipped with a motordriven impeller stirrer, sampling device and two needle valves. The autoclave was thermostatted by a water bath.

\section{Procedure}

The immobilized enzyme, the hydrogenation catalyst and the additives were transferred in the aqueous solution of D-glucose or a $1: 1$ D-glucose/D fructose mixture. The autoclave was sealed, flushed with hydrogen and placed in the water bath. After reaching the required temperature the autoclave was pressurized with hydrogen to the required level. The reaction was started by switching on the stirrer. The conversion was followed by HPLC analysis of samples withdrawn from the reaction mixture.

Analysis method

The HPLC system consisted of an M 6000 A pump (Waters Assoc.), Rheodyne 7125 injector, an $R 401$ differential refractometer (Waters Assoc.) and a cation-exchange resin column. Chromatographic conditions column dimensions: $30 \mathrm{~cm} * 7.0 \mathrm{~mm}$ ID; Aninex A $78 \%$ cross-linked resin $(7-11 \mu \mathrm{m})$ in the $\mathrm{Ca}(\mathrm{II})$-form; temperature: $85{ }^{\circ} \mathrm{C}$; flow rate: $0.6 \mathrm{ml} / \mathrm{min}$; eluent: degassed and deionized $\mathrm{H}_{2} \mathrm{O}$. The chromatographic procedure is described in more detail elsewhere ${ }^{8}$

\section{Results and discussion}

Glucose isomerase entrapped in cell material

We first studied Maxazyme GI-Immob. of Gist Brocades and Sweetzyme 0 of NOvO which consist of whole cells, containing the enzyme glucose isomerase immobilized in a gelatin-glutardialdehyde and in a glutardial- dehyde matrix, respectively ${ }^{7}$. Ruthenium, osmium, iridium, and platinum on carbon were applied in the hydrogenation of $1: 1 \quad \mathrm{D}-g$ lucose/D-fructose mixtures without enzyme (Table I) and in the presence of these enzyme systems (Tables II and III). The results clearly show a serious poisoning of the hydrogenation catalysts by the enzymes, except for the combination of Maxazyme GI-Immob. and ruthenium on carbon.

TABLE

Conversion and product composition for the 1:1 D-glucose/D-fructose hydrogenation ${ }^{a}$.

\begin{tabular}{rccccc} 
Catalyst & $\begin{array}{c}\text { Conversion } \\
\text { mole } \%\end{array}$ & $\begin{array}{c}\text { D-Glucose } \\
\text { mole } \%\end{array}$ & $\begin{array}{c}\text { D-Fructose } \\
\text { mole } \%\end{array}$ & $\begin{array}{c}\text { D-Mannitol } \\
\text { mole } \%\end{array}$ & $\begin{array}{c}\text { D-Glucitol } \\
\text { mole \% }\end{array}$ \\
\hline $5 \%$ Ru/C & 60 & 33 & 7 & 19 & 41 \\
$5 \%$ Os/C & 45 & 40 & 15 & 19 & 26 \\
$10 \%$ Ir/C & 20 & 48 & 32 & 10 & 10 \\
$5 \%$ Pt/C & 37 & 45 & 19 & 19 & 18 \\
\hline
\end{tabular}

a Conditions: $30.0 \mathrm{~g} \mathrm{D}-\mathrm{g}$ lucose, $30.0 \mathrm{~g}$ D-fructose, $1.0 \mathrm{~g}$ catalyst, $0.3 \mathrm{~g}$ $\mathrm{MgSO}_{4}, 0.5 \mathrm{~g} \mathrm{CaCO}_{3}, 250 \mathrm{ml} \mathrm{H} 20,60^{\circ} \mathrm{C}, 20 \mathrm{~kg} / \mathrm{cm}^{2} \mathrm{H}_{2}, \mathrm{pH}: 7.1-7.6, \mathrm{t}=$ $25 \mathrm{~h}$

TABLE II

Conversion and product composition for the $1: 1$ D-glucose/D-fructose hydrogenation in the presence of Sweetzyme $Q^{a}$.

\begin{tabular}{rccccc}
\hline Catalyst & $\begin{array}{c}\text { Conversion } \\
\text { mole } \%\end{array}$ & $\begin{array}{c}\text { D-Glucose } \\
\text { mole } \%\end{array}$ & $\begin{array}{c}\text { D-Fructose } \\
\text { mole } \%\end{array}$ & $\begin{array}{c}\text { D-Mannitol } \\
\text { mole } \%\end{array}$ & $\begin{array}{c}\text { D-Glucitol } \\
\text { mole } \%\end{array}$ \\
\hline $5 \% \mathrm{Ru} / \mathrm{C}$ & 16 & 43 & 41 & 6 & 10 \\
$5 \% \mathrm{OS} / \mathrm{C}$ & 13 & 45 & 42 & 6 & 7 \\
$10 \% \mathrm{Ir} / \mathrm{C}$ & 4 & 48 & 48 & 2 & 2 \\
$5 \% \mathrm{Pt} / \mathrm{C}$ & 9 & 44 & 45 & 5 & 6 \\
\hline
\end{tabular}

a Conditions: $30.0 \mathrm{~g}$ D-glucose, $30.0 \mathrm{~g}$ D-fructose, $3.0 \mathrm{~g}$ Sweetzyme Q, $1.0 \mathrm{~g}$ catalyst, $0.3 \mathrm{~g} \mathrm{MgSO}_{4}, 0.5 \mathrm{~g} \mathrm{CaCO}_{3}, 250 \mathrm{ml}, 60{ }^{\circ} \mathrm{C}, 20 \mathrm{~kg} / \mathrm{cm}^{2} \mathrm{H}_{2}$, $\mathrm{pH}=7.1-7.6, \mathrm{t}=25 \mathrm{~h}$. 
TABLE III

Conversion and product composition for the $1: 1$ D-glucose/D-fructose hydrogenation in the presence of Maxazyme GI-Immob. ${ }^{a}$.

\begin{tabular}{rcccccc}
\hline Catalyst & $\begin{array}{c}\text { Conversion } \\
\text { mole } \%\end{array}$ & $\begin{array}{c}\text { D-Glucose } \\
\text { mole } \%\end{array}$ & $\begin{array}{c}\text { D-Fructose } \\
\text { mole } \%\end{array}$ & $\begin{array}{c}\text { D-Mannitol } \\
\text { mole } \%\end{array}$ & $\begin{array}{c}\text { D-Glucitol } \\
\text { mole \% }\end{array}$ \\
\hline $5 \%$ Ru/C & 46 & 30 & 29 & 17 & 25 \\
$5 \%$ Os/C & 19 & 41 & 40 & 9 & 10 \\
$10 \% \mathrm{Ir} / \mathrm{C}$ & 8 & 46 & 46 & 4 & 4 \\
$5 \% \mathrm{Pt} / \mathrm{C}$ & 9 & 44 & 45 & 5 & 6
\end{tabular}

a Conditions: $30.0 \mathrm{~g}$ D-g1ucose, $30.0 \mathrm{~g}$ D-fructose, $10.0 \mathrm{~g}$ Maxazyme GIImmob., $1.0 \mathrm{~g}$ catalyst, $0.3 \mathrm{~g} \mathrm{MgSO}_{4}, 0.5 \mathrm{~g} \mathrm{CaCO}_{3}, 250 \mathrm{ml} \mathrm{H} \mathrm{H}_{2} \mathrm{O}, 60^{\circ} \mathrm{C}$, $20 \mathrm{~kg} / \mathrm{cm}^{2} \mathrm{H}_{2}, \mathrm{pH}=7.1-7.6, \mathrm{t}=25 \mathrm{~h}$.

The poisoning effect of these enzyme systems is further illustrated by comparison of Fig. 2 with Figs. 3 and 4 for copper on silica as the hydrogenation catalyst.

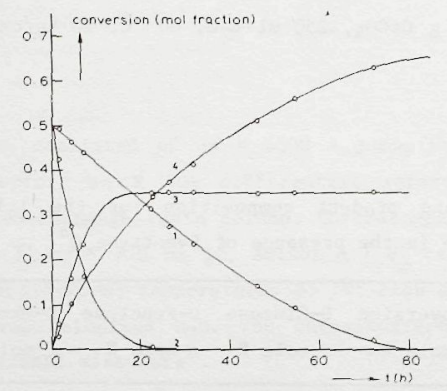

Fig. 2. Time course of $1: 1$ D-glucose/D-fructose hydrogenation over $\mathrm{Cu} / \mathrm{SiO}_{2}$.

$30.0 \mathrm{~g} \mathrm{D}$-glucose, $30.0 \mathrm{~g}$ D-fructose, $5.0 \mathrm{~g} 20 \% \mathrm{Cu} / \mathrm{SiO}_{2}, 0.3 \mathrm{~g}$ $\mathrm{MgSO}_{4}, 0.5 \mathrm{~g} \mathrm{CaCO}, 0.1 \mathrm{~g} \mathrm{Na} 2 \mathrm{~B}_{4} \mathrm{O}_{7} \cdot 10 \mathrm{H}_{2} \mathrm{O}, 0.05 \mathrm{~g}$ EDTA, $200 \mathrm{ml}$ $\mathrm{H}_{2} \mathrm{O}, 70{ }^{\circ} \mathrm{C}, 50 \mathrm{~kg} / \mathrm{cm}^{2} \mathrm{H}_{2}, \mathrm{pH} 7.1-7.6,800 \mathrm{rpm}$. D-Glucose (1), D-fructose (2), D-mannitol (3), D-glucitol (4).

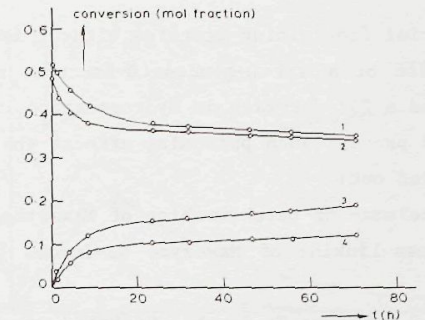

Fig. 3. The combi-process using $\mathrm{Cu} / \mathrm{SiO}_{2}$ and the enzyme Sweetzyme $\mathrm{Q}$. $30.0 \mathrm{~g} \mathrm{D}$-glucose, $30.0 \mathrm{~g} \mathrm{D}$-fructose, $5.0 \mathrm{~g}$ Sweetzyme $Q, 5.0 \mathrm{~g}$ $20 \% \mathrm{Cu} / \mathrm{SiO}_{2}, 0.3 \mathrm{~g} \mathrm{MgSO}, 0.5 \mathrm{~g} \mathrm{CaCO}_{3}, 0.1 \mathrm{~g} \mathrm{Na}_{2} \mathrm{~B}_{4} \mathrm{O}_{7} \cdot 10 \mathrm{H}_{2} \mathrm{O}$, $0.05 \mathrm{~g}$ EDTA, $200 \mathrm{mI} \mathrm{H} 0,70{ }^{\circ} \mathrm{C}, 50 \mathrm{~kg} / \mathrm{cm}^{2} \mathrm{H}_{2}$, $\mathrm{pH} 7.1-7.6,800$ rpm. D-Glucose (1), D-fructose (2), D-mannitol (3), D-glucitol (4)

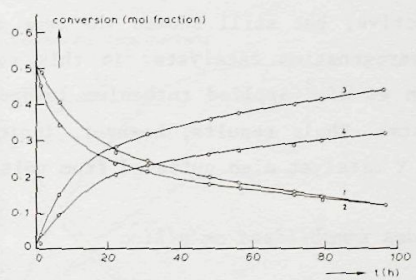

Fig. 4. The combi-process using $\mathrm{Cu} / \mathrm{SiO}_{2}$ and the enzyme Maxazyme GIImmob.

$30.0 \mathrm{~g}$ D-glucose, $30.0 \mathrm{~g}$ D-fructose, $15.0 \mathrm{~g}$ Maxazyme GI-Immob., $5.0 \mathrm{~g} 20 \% \mathrm{Cu} / \mathrm{SiO}_{2}, 0.3 \mathrm{~g} \mathrm{MgSO}_{4}, 0.5 \mathrm{~g} \mathrm{CaCO}_{3}, 0.1 \mathrm{~g} \mathrm{Na} \mathrm{B}_{4} \mathrm{O}_{7} .-$ $10 \mathrm{H}_{2} \mathrm{O}, 0.05 \mathrm{~g}$ EDTA, $200 \mathrm{mI} \mathrm{H} \mathrm{O}, 70{ }^{\circ} \mathrm{C}, 50 \mathrm{~kg} / \mathrm{cm}^{2} \mathrm{H}_{2}, \mathrm{pH} 7.1-7.6$, $800 \mathrm{rpm} . \mathrm{D}$-Glucose (1), D-fructose (2), D-mannitol (3), D-glucito1 (4).

This poisoning effect, which is more serious pronounced for Sweetzyme Q than for Maxazyme GI-Immob., is probably due to adsorption of mobile fragments from the immobilized glucose isomerase system onto the hydrogenation catalyst. For instance, column washing of Maxazyme GI-Immob. resulted in elution of $6 \%$ of the total enzyme material. Addition of 0.5 
g of this material (containing proteins without isomerizing activity) to the hydrogenation of a $1: 1 \mathrm{D}-\mathrm{glucose} / \mathrm{D}$-fructose mixture over ruthenium on carbon caused a $25 \%$ decrease in hydrogenation rate.

In order to prevent such poisoning effects the following experiments have been carried out:

(i) careful column- or batch-washing of Maxazyme GI-Immob. ${ }^{7}$;

(ii) extra cross-linking of Maxazyme GI-Immob. (with 5\% glutardialdehyde);

(iii) the use of Maxazyme Gi-Immob. which had functioned for $1050 \mathrm{~h}$ (its half-life time) in the industrial high $\mathrm{D}$-fructose corn syrup process;

(iv) the fixation of Maxazyme GI-Immob. in a metallic gauze during the hydrogenation reaction

(v) the addition of extra silica or activated carbon during the hydrogenation reactions in order to adsorb the mobile fragments;

(vi) some combinations of the above mentioned precautions.

The Maxazyme GI-Immob. preparations thus obtained and applied were stil sufficiently active, but still showed the same strong poisoning effect towards the hydrogenation catalysts. In this respect it may be noted that Ruddlesden et al. ${ }^{3}$ applied ruthenium loaded zeolite $Y$ in order to protect the metal. Their results, however, indicate that the ruthenium loaded zeolite $Y$ catalyst also suffered from poisoning effects.

Glucose isomerase immobilized on silica

Quite recently, Miles Kali-Chemie introduced a new type of immobilized glucose isomerase, Optisweet 22. This enzyme system consists of purified enzyme glucose isomerase anchored onto a silica support ${ }^{7}$. This purified enzyme system is more sensitive to species present in the hydrogenation formulation than the cellular enzyme preparations. For example traces of copper ions inhibit Optisweet $22^{7}$ as is shown from the slow D-glucose/D-fructose interconversion during the copper catalyzed hydrogenation (Fig. 5).

on the other hand, this inhibitory effect can easily be counteracted by the addition of trace (equimolar on copper ions) amounts of EDTA, which selectively forms a complex with copper ions. Fig. 6 clearly demonstrates the high activity of Optisweet 22 to maintain the D-glucose/D-fructose mixture at equilibrium, thus resulting in a $62 \%$ D-mannitol yield.

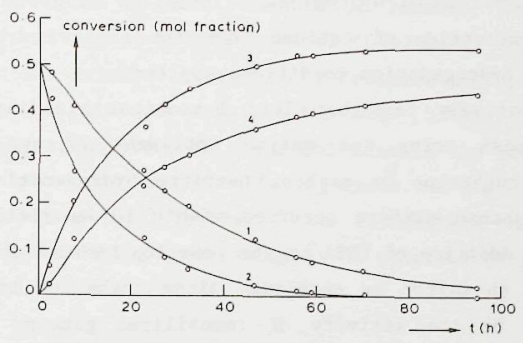

Fig. 5. The combi-process using $\mathrm{Cu} / \mathrm{SiO}_{2}$ and the enzyme optisweet 22 . $30.0 \mathrm{~g}$ D-glucose, $30.0 \mathrm{~g}$ D-fructose, $3.0 \mathrm{~g}$ Optisweet $22,5.0 \mathrm{~g}$ $20 \% \mathrm{Cu} / \mathrm{SiO}_{2}, 0.3 \mathrm{~g} \mathrm{MgSO}_{4}, 0.5 \mathrm{~g} \mathrm{CaCO}, 0.1 \mathrm{~g} \mathrm{Na} 2 \mathrm{~B}_{4} \mathrm{O}_{7} .1 \mathrm{H}_{2} \mathrm{O}, 200$ ml $\mathrm{H}_{2} \mathrm{O}, 70{ }^{\circ} \mathrm{C}, 50 \mathrm{~kg} / \mathrm{cm}^{2} \mathrm{H}_{2}, \mathrm{pH} 7.1-7.6,800 \mathrm{rpm}$. D-Glucose (1), D-fructose (2), D-mannitol (3), D-glucitol (4).

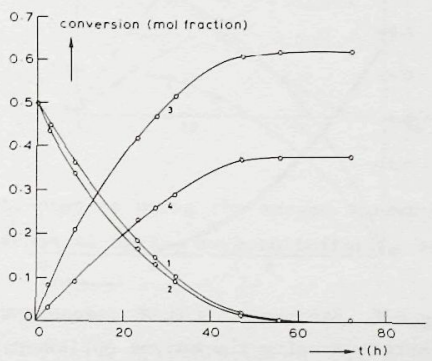

Fig. 6. Improvement of the activity of Optisweet 22 by EDTA in the combi-process using $\mathrm{Cu} / \mathrm{SiO}_{2}$ (compare with Fig. 5).

$30.0 \mathrm{~g}$ D-glucose, $30.0 \mathrm{~g}$ D-fructose, $3.0 \mathrm{~g}$ Optisweet $22,5.0 \mathrm{~g}$ $20 \% \mathrm{Cu} / \mathrm{SiO}_{2}, 0.3 \mathrm{~g} \mathrm{MgSO}_{4}, 0.5 \mathrm{~g} \mathrm{CaCO}_{3}, 0.1 \mathrm{~g} \mathrm{Na} 2 \mathrm{~B}_{4} 0_{7} .10 \mathrm{H}_{2} \mathrm{O}, 0.05$ $\mathrm{g}$ EDTA, $200 \mathrm{ml} \mathrm{H} \mathrm{H}_{2} \mathrm{O}, 70{ }^{\circ} \mathrm{C}, 50 \mathrm{~kg} / \mathrm{cm}^{2} \mathrm{H}_{2}, \mathrm{pH} 7.1-7.6,800 \mathrm{rpm}$. D-Glucose (1), D-fructose (2), D-mannitol (3), D-glucitol (4).

Comparison of Fig. 3 (Sweetzyme Q) and Fig. 4 (Maxazyme GI-Immob.) with Fig. 6 (Optisweet 22) shows that the poisoning effect exerted by optisweet 22 is less serious. It may be noted that EDTA has no influence 
on the carbohydrate hydrogenation reaction rate and that there was no further extraction of cations from the metal hydrogenation catalysts under the hydrogenation conditions applied.

A relatively fast but less D-mannitol yielding procedure is the combi-process using the enzyme optisweet 22 and the hydrogenation catalyst ruthenium on carbon. Complete hydrogenation of a $1: 1$ D-glucose/D-fructose mixture occurred within $10 \mathrm{~h}$, yielding $40 \%$ D-mannitol (Fig. 7). Addition of EDTA to the reaction mixture is not necessary with ruthenium on carbon as catalyst, since ruthenium ions show a positive influence on the activity of immobilized glucose isomerases ${ }^{7}$. Other hydrogenation catalysts under these hydrogenation conditions severely suffered from small amounts of mobile fragments exerted by optisweet 22 or from degradation products formed, causing a decrease in hydrogenation activity and stability.

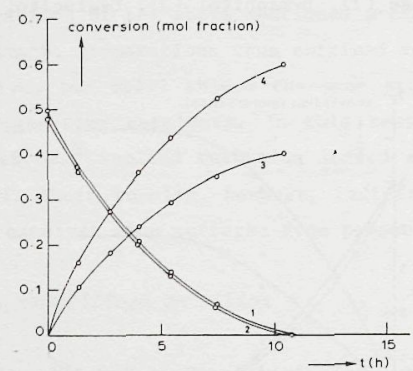

Fig. 7. The combi-process using the enzyme optisweet 22 and $\mathrm{Ru} / \mathrm{C}$.

$30.0 \mathrm{~g}$ D-glucose, $30.0 \mathrm{~g}$ D-fructose, $3.0 \mathrm{~g}$ Optisweet $22,1.0 \mathrm{~g}$ $5 \% \mathrm{Ru} / \mathrm{C}, 0.3 \mathrm{~g} \mathrm{MgSO}_{4}, 0.5 \mathrm{~g} \mathrm{CaCO}_{3}, 200 \mathrm{ml} \mathrm{H} \mathrm{H}_{2} \mathrm{O}, 70^{\circ} \mathrm{C}, 50 \mathrm{~kg} / \mathrm{cm}^{2}$ $\mathrm{H}_{2}, \mathrm{pH}$ 7.1-7.6, $800 \mathrm{rpm}$. D-Glucose (1), D-fructose (2), Dmannitol (3), D-glucitol (4).

As reported elsewhere ${ }^{6}$, an improvement of the selectivity of the D-mannitol formation from D-fructose by the hydrogenation over copper on silica is obtained by the addition of catalytic amounts of borates to the reaction mixture. The effect of borates on this selectivity, however, is suppressed when $\mathrm{CaCO}_{3}$ is used as buffer. We, therefore, applied magnesium hydrogen phosphate as both buffering and enzyme stabilizing agent in the presence of small amounts of borates, resulting in an increase in selectivity towards D-mannitol (0.67-0.72) from D-fructose, whereas the initial selectivity for the D-fructose hydrogenation in $1: 1$ D-glucose/D-fructose mixtures remained the same (0.92). The activity of the copper catalyst, however, is about $50 \%$ less in the presence of magnesium hydrogen phosphate as the buffering agent. On the other hand, the enzyme system (Optisweet 22) is really able to maintain the D-glucose/Dfructose equilibriun during the hydrogenation reaction (Fig. 8). In this case a D-mannitol yield of $66 \%$ was obtained.

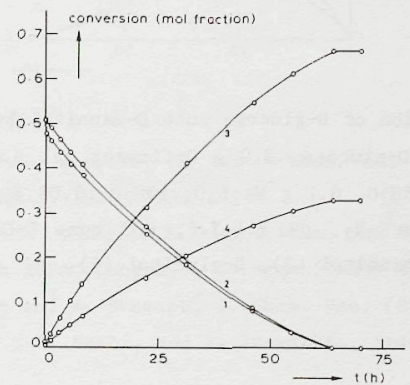

Fig. 8. The combi-process using the enzyme optisweet 22 and $\mathrm{Cu} / \mathrm{SiO}_{2}$ in the presence of $\mathrm{MgHPO}_{4}$ as both buffering and enzyme-stabilizing agent.

$30.0 \mathrm{~g} \mathrm{D}$-glucose, $30.0 \mathrm{~g}$ D-fructose, $3.0 \mathrm{~g}$ Optisweet $22,5.0 \mathrm{~g}$ $20 \% \mathrm{Cu} / \mathrm{SiO}_{2}, 1.0 \mathrm{~g} \mathrm{MgHPO}_{4} \cdot 3 \mathrm{H}_{2} \mathrm{O}, 0.1 \mathrm{~g} \mathrm{Na} 2 \mathrm{~B}_{4} \mathrm{O}_{7} \cdot 1 \mathrm{H}_{2} \mathrm{O}, 0.05 \mathrm{~g}$ EDTA, $200 \mathrm{~m} 1 \mathrm{H}_{2} \mathrm{O}, 70{ }^{\circ} \mathrm{C}, 50 \mathrm{~kg} / \mathrm{cm}^{2} \mathrm{H}_{2}, \mathrm{pH} 7.1-7.6,800 \mathrm{rpm}$. D-Glucose (1), D-fructose (2), D-mannitol (3), D-glucitol (4).

D-Glucose as starting material

It is shown in Fig. 9 that under these circumstances (magnesium hydrogen phosphate and borate addition) D-glucose can be used as starting material. in the combi-process, thus omitting prior enzymatic isomerization of D-glucose or the use of invert sugar.

The yield of D-mannitol ( $64 \%$ ) is about as high as in the case of a $1: 1$ D-glucose/D-fructose mixture as starting material. 


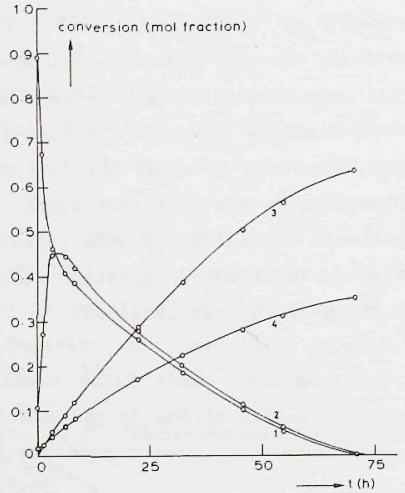

Fig. 9. Conversion of D-glucose into D-mannitol by the combi-process. $60.0 \mathrm{~g} \mathrm{D}$-glucose, $3.0 \mathrm{~g}$ Optisweet $22,5.0 \mathrm{~g} 20 \% \mathrm{Cu} / \mathrm{SiO}_{2}, 1.0 \mathrm{~g}$ $\mathrm{MgHPO}_{4} \cdot 3 \mathrm{H}_{2} \mathrm{O}, 0.1 \mathrm{~g} \mathrm{Na} 2 \mathrm{~B}_{4} \mathrm{O}_{7} \cdot 10 \mathrm{H}_{2} \mathrm{O}, 0.05 \mathrm{EDTA}, 200 \mathrm{ml} \mathrm{H} \mathrm{H}_{2} \mathrm{O}, 70{ }^{\circ} \mathrm{C}$, $50 \mathrm{~kg} / \mathrm{cm}^{2} \mathrm{H}_{2}, \mathrm{pH} 7.1-7.6,800 \mathrm{rpm}$. D-Glucose (1), D-fructose (2), D-mannitol (3), D-glucitol (4).

\section{Conclusions}

The results show that glucose isomerase immobilized on silica (Optisweet 22) in combination with a copper hydrogenation catalyst can be conveniently applied in the present combi-process. High yields of D-mannitol (62-66\%) have been obtained with D-glucose or 1:1 D-glucose/D-fructose mixtures as starting material. Small amounts of $\mathrm{CaCO}_{3}$ and $\mathrm{MgSO}_{4}$ or $\mathrm{MgHPO}_{4}$ have to be present in order to maintain sufficien enzyme activity (i.e. $\mathrm{pH} \sim 7$ and $\mathrm{Mg}$ (II) required by the enzyme), whereas the enzyme has to be protected against traces of $\mathrm{Cu}$ (II) from the copper catalyst by the addition of equimolar amounts of EDTA. Glucose isomerases entrapped in whole cell materials, Maxazyme GI-Immob. and Sweetzyme $Q$, result in a more serious poisoning of the hydrogenation catalyst and are, therefore, less applicable than optisweet 22 in a single batch procedure.

The combination of Optisweet 22 with ruthenium on carbon provides a faster method for the conversion of $1: 1 \quad \mathrm{D}$-glucose/D-fructose mixtures into D-mannitol and D-glucitol. The D-mannitol yield, however, is much lower $(40 \%)$.

The occurrence of non-enzymatic isomerization and degradation reactions is negligible under the reaction conditions used. As to the selectivity the present combi-process is a great improvement on other approaches reported in the literature in the production of D-mannitol.

\section{Acknowledgement}

Mr. E. Wurtz is acknowledged for technical assistance during the hydrogenation experiments.

\section{References}

1. M. Makkee, A.P.G. Kieboom, H. van Bekkum, and J.A. Roels, J. Chem. Soc., Chem. Commun. 1980, 930

2. M. Makkee, A.P.G. Kieboom, H. van Bekkum, and J.A. Roels, Abstracts of Papers, 29th IUPAC Congress, Cologne (1983) 434.

3. J.F. Rudd1esden and A. Stewart, J. Chem. Res. (S), 1981, 378.

4. M.W. Kearsley, S.H. Satti, and I. Tregaskis, Starch 32 (1980) 169.

5. Chapter 2.

6. Chapter 3.

7. Chapter 5.

8. Chapter 8. 
8. HPLC ANALYSIS OF REACTION MITITURES CONTAINING MONOSACCHARIDES AND ALDITOLS*

Introduction

The valuable nutritive sweetener D-mannitol is comnercially produced by high pressure hydrogenation of invert sugar with Raney-Nickel as the catalyst. As only D-fructose gives rise to partial D-mannitol formation the overall D-mannitol yield is less than $30 \%$. Searching for an alternative procedure for the preparation of D-mannitol, we have in study the combi-process depicted in scheme $\mathrm{I}^{1}$.

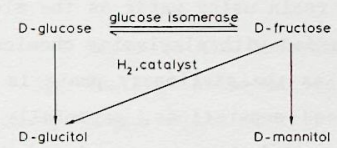

Scheme I. Combi-process for the preparation of D-mannitol: simultaneous enzymatic interconversion and metal catalyzed hydrogenation of D-g1ucose/D-fructose mixtures.

This combined single batch procedure involves the enzymatic interconversion of D-glucose and D-fructose (immobilized glucose isomerase) with concomitant and preferential hydrogenation of D-fructose (copper on silica as the catalyst). Up to $65 \%$ yields of D-mannitol have been obtained $^{1}$.

The investigation of the simultaneous isomerization and hydrogena-

\footnotetext{
* Accepted for publication in 'International Sugar Journal'.
} 
tion of D-glucose/D-fructose mixtures ${ }^{1}$ required a quantitative fast analysis technique for the determination of D-glucose, D-fructose, D-mannitol and D-glucitol. In addition, it was sometimes of importance to detect the formation of possible by-products as D-psicose, D-sorbose, D-tagatose and D-mannose.

Gas chromatography (GC) is a well-developed and accurate analytical tool for the analysis of carbohydrate mixtures. However, quantitative derivatization of the samples is required to obtain sufficient volatility of the carbohydrate components. Moreover, GC analysis shows separate peaks for the different anomeric furanose and pyranose forms of reducing sugars which complicates quantitative interpretation. Since the GC method is also rather time-consuming and cannot easily be automated because of the required derivatization step, we have chosen for HPLC as the analytical tool.

During the last decade HPLC has become a sophisticated and rapid method for the analysis of carbohydrate mixtures. At present, two types of stationary phases are commonly used in the HPLC analysis of carbohydrates and related compounds:

- alkylamine-modified silica using acetonitrile/water as the eluent ${ }^{2-5}$ - cation exchange resin using water as the eluent ${ }^{6-11}$.

Silica can be modified with alkylamine chemically as well as physically. A modified silica as the stationary phase is resistent to high pressure and results in good separations, especially of disaccharides, at room temperature. The carbohydrates are eluted in the order of increasing degree of polymerization, the monosaccharides first, subsequently the disaccharides and then oligosaccharides. For a routine analysis, there is the problem that both retention times and response factors are highly sensitive to small variations in the composition of the eluent acetonitrile/water and to small alterations in column temperature ${ }^{5}$. Furthermore, solubility problems of ten arise in the acetonitrile/water solvent system and the signal to noise ratio is rather poor using RI-detection. Finally, acetonitrile is expensive and toxic. The above mentioned reasons have, therefore, led us to choose cation exchange resins as the stationary phase together with water as the eluent for the present investigations. This despite of the fact that the pressure resistance of this system is less than that of modified silica.

\section{Cation exchange resins in carbohydrate HPLC-analysis}

The main task of the cation exchange resin is to immobilize the cation. In carbohydrate separation resins of the sulfonated polystyrenedivinylbenzene are most frequently used. These rigid gel type resins become porous on swelling, with the pore size depending on the degree of cross-linking (as indicated by the percentage of divinylbenzene in the copolymer). A resin with a lower percentage of cross-linking has a more open structure permeable to higher molecular weight substances than a higher cross-linked resin. It has, however, a lower physical resistance to shrinking and swelling. Because of high porosity and high concentration of functional groups within their chemical structure, ion exchange resins have a high effective capacity. Finally, the remarkable chemical stability of ion exchange resins makes them useful under a wide variety of conditions including temperature, organic solvents, reducing and oxidizing agents.

We will focus our attention on the sulfonated polystyrene-divinylbenzene cation exchange resin. The various carbohydrate-resin interactions which may play a role in the separation process have been summarized below:

- Ligand exchange: based on the interaction of the carbohydrate with the cation;

- Reverse phase partitioning: based on the distribution of carbohydrates between a polar mobile phase and the nonpolar resin backbone;

- Nomar phase partitioning: based on the distribution of sample molecules between intra-particle ('bound') mobile phase and the bulk mobile phase;

- Size exclusion based on the physical exclusion of carbohydrates which are too large to penetrate part of the effective pore structure of the resin.

In carbohydrate analysis the character of the cation of the exchange resin is a major factor in determining the quality of the separation. The separation is to a large extent due to differences in coordinating ability of the carbohydrate with the cation of the resin. It has been shown by MMR and electrophoresis studies, both carried out in the presence of metal ions ${ }^{6,11}$, that an ax-eq-ax sequence of three adjacent hydroxyl groups in cyclohexitol systems or in pyranose rings, or an all- 
cis arrangement of three vicinal hydroxyl groups in furanose rings gives rise to tridentate chelation with suitable metal cations ( $K_{\text {ass }}=1-5$ $\mathrm{mol}^{-1}$ in water at $25^{\circ} \mathrm{C}$ ). The same holds for a threo-threo arrangement of three adjacent hydroxyls in alditols ${ }^{12,13}$. In general, the strength of coordination of two vicinal hydroxyl groups is much weaker ( $K_{\text {ass }}$ < $0.1 \mathrm{~mol}^{-1}$ ). It has been reported by Grayll that an appropriate choice of the cation may easily result in a rapid baseline separation of a mixture of D-glucose, D-xylose, D-galactose, D-arabinose, and D-mannose.

The degree of cross-linking is also of importance. In particular, mixtures of oligosaccharides of different molecular weight are better separated with cation exchange resins with a lower degree of crosslinking, as the separation mechanism of size exclusion (molecular sieving) becomes of greater importance. This was shown by Scobell and Brobst ${ }^{9}$ for the analysis of acid hydrolyzed corn syrups over four $\mathrm{Ag}$ (I) resins with different degrees of cross-linking. Although the effect of partial $\mathrm{Ag}$ (I) loading is not yet clearly understood, it provides a much better method for the separation of oligosaccharides than the use of resins in other cationic forms ( $\mathrm{Ca}(\mathrm{II})$ and $\mathrm{Pb}(\mathrm{II})$ ). However, of the many cation exchange resins studied $6,10,11,14, \mathrm{Ca}$ (II) exchange resin gave the best overall performance for the separation of monosaccharides, which is of most importance for the present investigation.

It should be noted that mono- and disaccharides containing an anomeric hydroxyl (e.g. reducing sugars) of ten show broader peaks than those without an anomeric hydroxyl, in particular at lower temperature. This is caused by the rather slow rate of mutarotation and the different strengths of coordination of the various anomers of the former under the chromatographic conditions. Angyal et al. ${ }^{6}$ and Verhaar and Kuster ${ }^{14}$ have found that the addition of $0.001 \mathrm{M}$ triethylamine, which catalyzes the mutarotation reaction, results in an efficient separation of various carbohydrate mixtures over a resin in the $\mathrm{Ca}$ (II) form at $30-50{ }^{\circ} \mathrm{C}$.

On the basis of these literature data we have developed a convenient HPLC procedure for the quantitative analysis of reaction mixtures containing both monosaccharides and sugar alcohols. The effect of particle size, temperature and flow rate has been examined.

\section{Experimental}

Apparatus

The HPLC system consisted of an M 6000 A pump (Waters Ass.), a Rheodyne 7125 injector or a Dupont 834 autoinjector fitted with a Rheodyne 7010 injector and an R 401 differential refractometer (Waters Ass.).

Chromatographic grade tubings (SS 316 Lichroma) $25 \mathrm{~cm} * 4.0 \mathrm{~mm}$ ID and $30 \mathrm{~cm} * 7.8 \mathrm{~mm}$ ID with the appropriate Parker Hannifin end fittings were obtained from Bio-Rad Lab. Chromatographic grade tubing Apollo (SS 316 Lichroma) $30 \mathrm{~cm} * 7.0 \mathrm{~mm}$ ID with the appropriate valco end fittings were obtained from Betron and Chrompack, respectively.

Chromatographic conditions

Unless otherwise specified the following conditions were used throughout: Deionized and degassed water of $85^{\circ} \mathrm{C}$ as the eluent; colum temperature of $85{ }^{\circ} \mathrm{C}$; detector temperature of $35^{\circ} \mathrm{C}$; detector attenuation of $16 *$; recorder sensitivity of $10 \mathrm{mV}$ full scale; sample concentration of $1-3 \%(w / w)$ carbohydrates in water; sample volume of $20-50 \mu 1$.

Materials

The HPLC column Aminex HPX $87 \mathrm{C}$, obtained from Bio Rad Lab., had the following specifications: column ( $30 \mathrm{~cm} * 7.8 \mathrm{~mm}$ ID); chromatographic resin Aminex A 7 (particle size $7-11 \mu \mathrm{m}$ ) in the $\mathrm{Ca}(\mathrm{II})$ form. The chromatographic resins Aminex A 7 (particle size 7-11 $\mu \mathrm{m}$ ) and Aminex A 5 (particle size 10-15 $\mu \mathrm{m}$ ) were supplied by Bio Rad Lab. in the $\mathrm{Na}$ (I) form and were converted into the $\mathrm{Ca}$ (II) form (see column preparation). The resin matrix had the following specifications: sulfonic acid; exchange capacity: $1.7 \mathrm{meq} / \mathrm{ml}$; maximum allowable temperature: $150{ }^{\circ} \mathrm{C}$; maximum allowable pressure: 5000 psi.

D-Psicose was prepared by the oxidation of 1,$2 ; 4,5$-di-0-isopropy1idene- $\alpha-D-f$ ructopyranose and the subsequent reduction of $1,2: 4,5-\mathrm{di}-0-$ isopropylidene- $\alpha-D$-fructopyran-3-ulose ${ }^{15}$. The desired product was obtained by liquid chromatography, using the cation exchange resin Bio Rad AG $50 \mathrm{~W}-\mathrm{X} 8$ in the $\mathrm{Ca}$ (II) form and water as eluent. D-Psicose was identified by ${ }^{13} \mathrm{C}$ NMR ${ }^{16}$. D-Xylulose was prepared by the isomerization of 
D-xylose using glucose isomerase, followed by liquid chromatography ${ }^{17}$ over the anion exchange resin Bio Rad AG $1-X 8$ in the bisulfite form using a $3: 1$ propanol/water mixture as the eluent. All other chemicals used were of analytical grade and were commercially available.

Colum preparation

The procedure used for the column preparation is based on literature methods ${ }^{7,14}$ with some modifications.

- A suspension of cation exchange resin Aminex A 5 or Aminex A 7 (ca. $1.5 \mathrm{~g} / \mathrm{ml}$ column content) was boiled under reflux for $0.5 \mathrm{~h}$ in $6 \mathrm{M} \mathrm{HCl}$ $(50 \mathrm{ml})$. The resin was filtered off and the procedure was repeated. Then the resulting slurry was cooled to room temperature and diluted with an equal volume of deionized water. The resin was filtered of $f$, washed with deionized water $(500 \mathrm{ml})$, stirred with $0.5 \mathrm{M}$ calcium nitrate $(100 \mathrm{ml})$ for $0.5 \mathrm{~h}$, and filtered of $\mathrm{f}$. This procedure was repeated three times. The resulting resin was then stirred with deionized water $(100 \mathrm{ml})$. This washing was repeated three times.

- The analysis column was fitted with a stainless steel filter on top and a pre-column below. A filling reservoir was connected to the precolumn.

- The resin was slurried up in deionized water and put into the filling reservoir, which was subsequently filled up with deionized water and connected to the eluent pump.

- Deionized water was pumped through at a flow rate of $1.5 \mathrm{ml} / \mathrm{min}$. After reaching a pressure drop of 50 psi per $\mathrm{cm}$ bed height, deionized water was pumped through for one hour in such a way as to maintain this pressure drop.

- The analysis column was disconnected, filled off flatly and fitted with a stainless steel filter.

\section{Results and discussion}

The influence of the particle size of the cation exchange resin

The effect of the particle size on the chromatographic efficiency has been studied by comparison of the $\mathrm{Ca}$ (II) cation exchange resins Aminex A 5, Aminex A 7, which differ only in particle size, and the commercially available analysis column Aminex HPX $87 \mathrm{C}$ in the HPLC analysis of a mixture of D-g1ucose, D-fructose, D-mannitol and D-glu- citol (Fig. I and Table I).
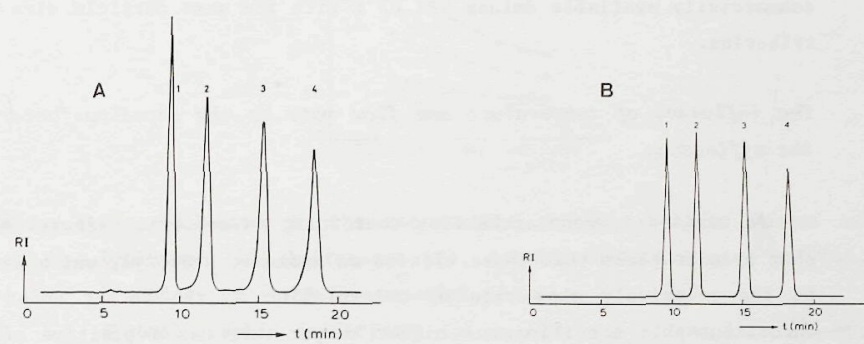

Fig. 1. Effect of particle size distribution on the efficiency of Dglucose (1), D-fructose (2), D-mannitol (3), and D-glucitol (4). Chromatographic conditions: column ( $30 \mathrm{~cm} * 7.8 \mathrm{~mm} \mathrm{ID})$; stationary phase: sulfonated polystyrene-divinylbenzene resin; eluent: $\mathrm{H}_{2} \mathrm{O}$; flow rate: $0.6 \mathrm{ml} / \mathrm{min}$; temperature: $85^{\circ} \mathrm{C}$.

A) Aminex $\mathrm{A} 5$ in $\mathrm{Ca}$ (II) form $(10-15 \mu \mathrm{m})$.

B) Aminex $\mathrm{A} 7$ in $\mathrm{Ca}(\mathrm{II})$ form $(7-11 \mu \mathrm{m})$.

TABLE I

Effect of particle size of $\mathrm{Ca}(\mathrm{II})$ resins on the efficiency ${ }^{\mathrm{a}}{ }^{\mathrm{b}}$

\begin{tabular}{lccc}
\hline $\begin{array}{c}\text { Ca(II) resin } \\
\text { Particle size (um) }\end{array}$ & $\begin{array}{c}\text { Aminex A } \\
10-15\end{array}$ & $\begin{array}{c}\text { Aminex A } 7 \\
7-11\end{array}$ & $\begin{array}{c}\text { Aminex HPX 87 C } \\
7-11\end{array}$ \\
\hline D-Glucose & 3600 & 4500 & 3100 \\
D-Fructose & 4900 & 7500 & 4800 \\
D-Mannitol & 6100 & 11000 & 7600 \\
D-Glucitol & 5800 & 10500 & 7300 \\
\hline
\end{tabular}

a Chromatographic conditions: colunn dimension $30 \mathrm{~cm} * 7.8 \mathrm{~mm}$ ID elvent: $\mathrm{H}_{2} \mathrm{O} ;$ flow rate: $0.6 \mathrm{~min}$ temperature: $85{ }^{\circ} \mathrm{C}$

b Efficiency: number of theoretical plates $\mathrm{N}=5.54 *$ $\left(t_{r} / w_{\frac{1}{2}}\right)^{2}$, in which $t_{r}=$ retention time and $\mathrm{w}_{\frac{1}{2}}=$ peak width at half height ${ }^{18}$. 
The results clearly show the favourable effect of smaller particles on the efficiency and peak form. It may also be concluded that the efficiency of the home-prepared column is about $50 \%$ higher than that of the commercially available Aminex HPX $87 \mathrm{C}$ with the same particle size distribution.

The influence of temperature and flow rate on the capacity factor and the efficiency

As mentioned, monosaccharides containing an anomeric hydroxyl of ten show broader peaks than those without an anomeric hydroxyl, which is due to the relatively slow rate of mutarotation of the former under the chromatographic conditions. A higher temperature has a positive effect on the efficiency since both the rate of mass transfer and the rate of mutarotation increase. On the other hand, the complexation strength of the carbohydrate with the cation will decrease at higher temperature. Therefore, the capacity factor

$$
k^{\prime}=\frac{t_{r}-t_{0}}{t_{0}}
$$

in which $t_{r}=$ retention time of a compound that coordinates to the cation, and $t_{0}=$ retention time of an unretained compound ${ }^{18}$, will also decrease at higher temperatures. Fig. 2 illustrates the influence of the temperature on the capacity factors with various flow rates and different particle size distributions of the cation exchange resins. At each temperature identical retention volumes were observed at different flow rates $(0.1-1.0 \mathrm{ml} / \mathrm{min}$ ). Also the particle size distribution (Aminex A 5 $(10-15 \mu \mathrm{m})$ and Aminex A $7(7-11 \mu \mathrm{m}))$ has no effect on the retention volume.

The temperature dependency D-glucitol (4) $>$ D-mannitol (3) $>$ D-fructose (2) > D-glucose (1) D-mannose (5) myo-inositol (6) clearly parallels the order of $\mathrm{Ca}$ (II) complexation strenghts ${ }^{6,11-13}$. The decrease in capacity factor at increasing temperature will therefore be due to a decrease of $\mathrm{Ca}$ (II) complexation of D-glucitol, D-mannitol and D-fructose.

The effect of flow rate on the efficiency at different temperatures is shown in Fig. 3.

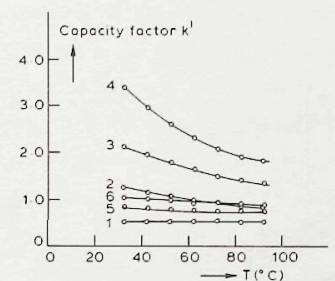

Fig. 2. The influence of the temperature on the capacity factor of D-glucose (1), D-fructose (2), D-mannitol (3), D-glucitol (4) D-mannose (5), and myo-inositol (6).

Chromatographic conditions: column ( $30 \mathrm{~cm} * 7.0 \mathrm{~mm}$ ID); eluent: $\mathrm{H}_{2} \mathrm{O}$; stationary phase: sulfonated polystyrene-divinylbenzene resin; Aminex A 5 in the $\mathrm{Ca}(\mathrm{II})$ form $(10-15 \mu \mathrm{m})$, and Aminex A 7 in the $\mathrm{Ca}(\mathrm{II})$ form $(7-11 \mu \mathrm{m})$; flow rates of $0.1,0.3,0.6$, and $1.0 \mathrm{ml} / \mathrm{min}$.

(Each point is a coincidence of eight measurements at different flow rates and particle size distributions (see text)).

The behaviour of both cyclic and acyclic carbohydrates without an anomeric hydroxyl, i.e. myo-inositol, D-glucitol and D-mannitol, is quite different from that of D-glucose, D-mannose and D-fructose. Clearly, this difference is due to mutarotation phenomena of the latter compounds during the chromotagraphic separation. At higher temperatures, the efficiency picture of these mutarotating monosaccharides shows more resemblance to that of the other polyhydroxy compounds, as is demonstrated by Fig. 4. This is clearly due to the increased rate of mutarotation.

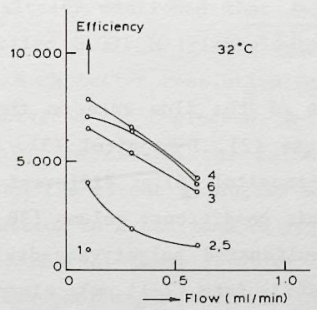



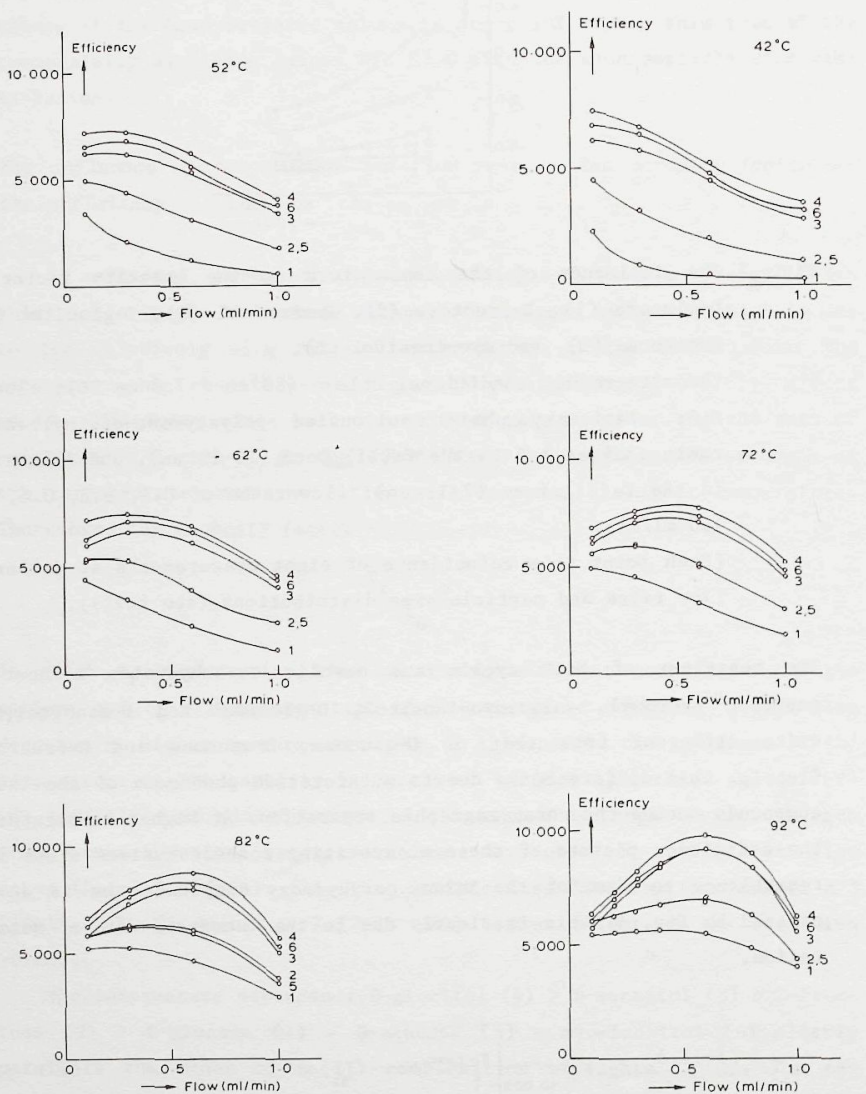

Fig. 3. The influence of the flow rate on the efficiency of $D-g l u c o s e$ (1), D-fructose (2), D-mannitol (3), D-glucitol (4), D-mannose (5), and myo-inositol (6) at different temperatures.

Chromatographic conditions: column ( $30 \mathrm{~cm} * 7.0 \mathrm{~mm} \mathrm{ID})$; stationary phase: sulfonated polystyrene-divinylbenzene resin; Aminex A 7 in the $\mathrm{Ca}(\mathrm{II})$ form $(7-11 \mu \mathrm{m})$; eluent: $\mathrm{H}_{2} \mathrm{O}$.
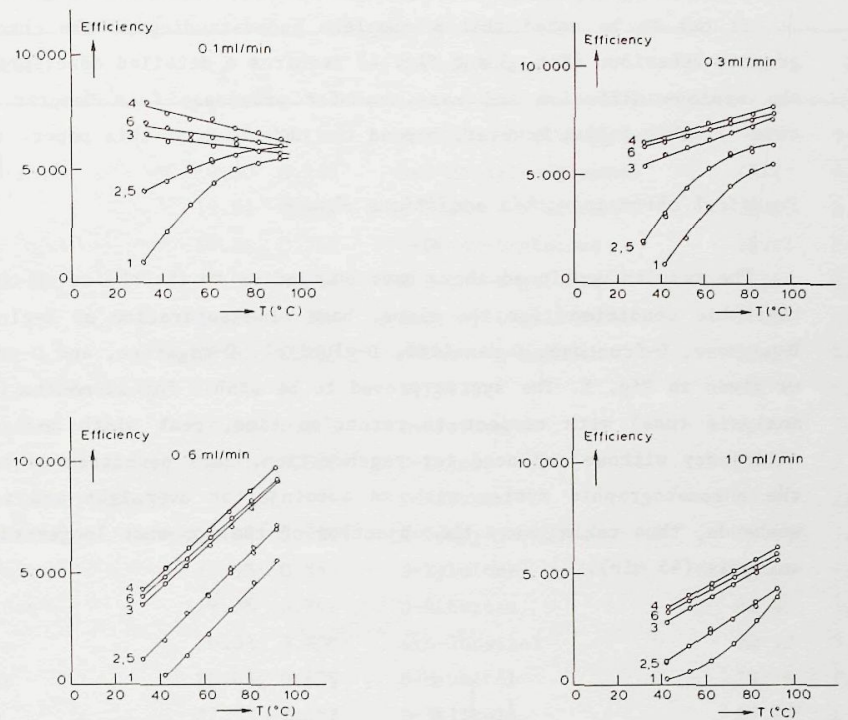

Fig. 4. The influence of the temperature on the efficiency of D-glucose (1), D-fructose (2), D-mannitol (3), D-glucitol (4), D-mannose (5), and myo-inositol at different flow rates.

Chromatographic conditions: column (30 cm * 7.0 mm ID); stationary phase: sulfonated polystyrene-divinylbenzene resin; Aminex $\mathrm{A} 7$ in the $\mathrm{Ca}(\mathrm{II})$ form $(7-11 \mu \mathrm{m})$; eluent: $\mathrm{H}_{2} \mathrm{O}$.

In this respect, we already mentioned that Angyal et al. ${ }^{6}$ and Verhaar and Kuster ${ }^{14}$ have applied $0.001 \mathrm{M}$ triethylamine (TEA) in water as the eluent. In this way a much better resolution (a higher capacity factor) and efficiency were obtained for D-glucose, D-fructose and D-mannose at lower temperature, which is due to the amine-catalyzed mutarotation. Unfortunately, TEA from the eluent gradually displaces $\mathrm{Ca}$ (II) from the cation exchanger, resulting in a decrease of retention times and separation efficiency in due course. Immobilization of TEA $(e . g$. in the form of a weak base ion exchanger) might overcome this disadvantage. Another 
possibility is a partly exchanged cation exchange resin, where free sulfonic acid groups might catalyze the rate of mutarotation.

It has to be noted that a complete understanding of the chromatographic behaviour (Fig. 3 and Fig. 4) requires a detailed description of the various diffusion and mass transfer processes (van Deemter equa$\left.\operatorname{tion}^{18}\right)$. This falls, however, beyond the objective of this paper.

Practical chromatographic conditions chosen

The results mentioned above have enabled us to the choice of chromatographic conditions for the almost base line separation of D-glucose, D-mannose, D-fructose, D-mannitol, D-glucitol, D-tagatose, and D-psicose as given in Fig. 5. The system proved to be stable for 12 months $(6,500$ analysis runs) with respect to retention time, peak width and colum efficiency without any need for regeneration. This permitted us to use the chromatographic system with an autoinjector overnight and in the weekends, thus taking away the objection of the somewhat longer time of analysis ( $45 \mathrm{~min}$ ).

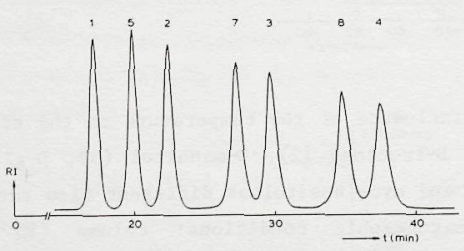

Fig. 5. HPLC analysis of an aqueous mixture of D-glucose (1), D-fructose (2), D-mannitol (3), D-glucitol (4), D-mannose (5), D-tagatose (7), and D-psicose (8).

Chromatographic conditions: column ( $30 \mathrm{~cm} * 7.0 \mathrm{~mm}$ ID); stationary phase: sulfonated polystyrene-divinylbenzene resin; Aninex A 7 in the $\mathrm{Ca}(\mathrm{II})$ form $(7-11 \mu \mathrm{m})$; eluent: $\mathrm{H}_{2} \mathrm{O}$; temperature: $62{ }^{\circ} \mathrm{C}$; flow rate: $0.3 \mathrm{ml} / \mathrm{min}$.

The retention times and the capacity factors of a number of mono- and disaccharides and sugar alcohols are summarized in Table II.
TABLE II

Retention times (min) and capacity factors for a number of carbohydrates ${ }^{a}$ b

\begin{tabular}{|c|c|c|c|c|c|}
\hline Carbohydrate & $t_{r}$ & $k^{\prime}$ & Carbohydrate & $t_{r}$ & $k^{\prime}$ \\
\hline Raffinose & 12.48 & 0.121 & Methyl $a$-D-glucopyranoside & 17.66 & 0.587 \\
\hline Cellobiose & 13.80 & 0.240 & 3-0-Methy1-D-glucose & 16.20 & 0.455 \\
\hline Sucrose & 13.92 & 0.251 & 2-Deoxy-D-glucose & 18.20 & 0.635 \\
\hline Maltose & 14.31 & 0.286 & 6-Deoxy-D-glucose & 18.62 & 0.673 \\
\hline Isomaltulose & 14.62 & 0.313 & 2-Deoxy-D-galactose & 20.64 & 0.854 \\
\hline Lactose & 14.86 & 0.335 & 6-Deoxy-D-galactose & 22.14 & 0.989 \\
\hline Lactulose & 16.62 & 0.493 & 6-Deoxy-D-mannose & 20.07 & 0.803 \\
\hline 6-0- $\alpha-D-G l u c o p y r a n o s y 1-$ & & & D-Xylose & 14.00 & 0.707 \\
\hline -D-mannitol & 18.66 & 0.676 & D-Arabinose & 22.47 & 1.019 \\
\hline Lactitol & 20.21 & 0.816 & D-Lyxose & 23.40 & 1.102 \\
\hline 6-0- $\alpha-D-G 1$ ucopyranosy1- & & & D-Ribose & 39.10 & 2.513 \\
\hline -D-glucitol & 22.04 & 0.980 & 2-Deoxy-D-ribose & 23.13 & 1.078 \\
\hline D-Glucose & 17.03 & 0.530 & $D$-Xylulose & 22.56 & 1.027 \\
\hline D-Galactose & 19.38 & 0.741 & D-Ribulose & 36.46 & 2.276 \\
\hline D-Mannose & 20.03 & 0.800 & myo-Inositol & 22.13 & 0.988 \\
\hline D-Altrose & 20.43 & 0.835 & D-Mannitol & 29.79 & 1.676 \\
\hline D-Allose & 27.35 & 1.457 & D-Talitol & 30.13 & 1.707 \\
\hline D-Talose & 36.09 & 2.242 & Galactitol & 35.57 & 2.196 \\
\hline L-Sorbose & 19.49 & 0.751 & D-Glucito1 & 37.33 & 2.354 \\
\hline D-Fructose & 22.51 & 1.022 & Ribitol & 24.47 & 1.198 \\
\hline D-Tagatose & 27.11 & 1.436 & D-Arabinitol & 30.05 & 1.700 \\
\hline \multirow[t]{3}{*}{ D-Psicose } & 34.70 & 2.117 & Xylitol & 39.05 & 2.508 \\
\hline & & & Pentaerythritol & 24.60 & 1.210 \\
\hline & & & Erythritol & 25.64 & 1.304 \\
\hline
\end{tabular}

a Chromatographic conditions: column ( $30 \mathrm{~cm} * 7.0 \mathrm{~mm}$ ID); Aminex A 7 in $\mathrm{Ca}($ II) form (7-11 $\mu \mathrm{m})$; eluent: $\mathrm{H}_{2} \mathrm{O}$; temperature: $62{ }^{\circ} \mathrm{C}$; flow rate: $0.3 \mathrm{ml} / \mathrm{min}$.

${ }^{b}$ Unretained $\mathrm{Ca}\left(\mathrm{ClO}_{4}\right)_{2}: \mathrm{t}_{0}=11.13 \mathrm{~min}$.

For the enzymatic isomerization of D-glucose the only reaction products are D-glucose and D-fructose, whereas the hydrogenation of D-glucose, $D$-fructose and invert sugar (D-g1ucose:D-fructose $=1: 1$ ) under mild conditions leads to a mixture of D-glucose, D-fructose, D-mannitol, and D-glucitol. In these cases a very rapid and quantitative analysis of 
the reaction mixture is obtained within 6 min over an HPLC column ( $25 \mathrm{~cm}$ 7 in the $C_{a}$ (II) form at higher tempera* $4.0 \mathrm{~mm}$ ID) containing Aminex A 7 in the Ca(II) ture $\left(85^{\circ} \mathrm{C}\right)$ and with a $\mathrm{flow}$ rate of $0.5 \mathrm{ml} / \mathrm{min}$ as given in Fig. 6 . The method is suitable for automation and operates with water as the eluent and RI detection.

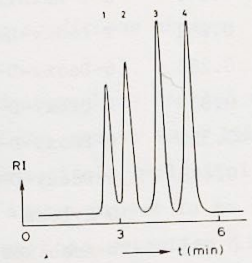

Fig. 6. HPLC analysis of an aqueous mixture of D-glucose (1), D-fructose (2), D-mannitol (3), and D-glucitol (4).

Chromatographic conditions: column $(25 \mathrm{~cm} * 4.0 \mathrm{~mm}$ ID); stationary phase: sulfonated polystyrene-divinylbenzene resin; Aminex ; A 7 in the $\mathrm{Ca}(\mathrm{II})$ form $(7-11 \mu \mathrm{m})$; eluent: $\mathrm{H}_{2} \mathrm{O}$; ${ }^{\circ} \mathrm{C}$; flow rate: $0.5 \mathrm{ml} / \mathrm{min}$.

\section{Acknowledgements}

Dr. F. van Rantwijk and Dr. C. Olieman are acknowledged for technical assistance.

\section{$\underline{\text { References }}$}

M. Makkee, A.P.G. Kieboom, H. van Bekkum, and J.A. Roe1s, J. Chem. Soc., Chem. Commun. 1980 930; A.P.G. Kieboom and H. van Bekkum, Rec1. Trav. Chim. Pays-Bas 103 (1984) 1.

2. R. Schwarzenbach, J. Chromatogr. 117 (1976) 206

3. E.C. Conrad and J.K. Palmer, Food Technol., October (1976) 84.

4. K. Aitzetmüller, Chromatographia 13 (1980) 432.

5. C. Brons and C. Olieman, J. Chromatogr. 259 (1983) 79.
6. S.J. Angyal, G.S. Bethell, and R.J. Beveridge, Carbohydr. Res. 73 (1979) 9.

7. M.R. Ladisch, A.L. Huebner, and G.T. Tsao, J. Chromatogr. 147 (1978) 185.

8. H.D. Scobell, K.M. Brobst, and E.M. Steele, Cereal Chem. 54 (1977) 905 .

9. H.C. Scobel1 and K.M. Brobst, J. Chromatogr. 212 (1981) 51.

10. R.W. Goulding, J. Chromatogr. 103 (1975) 229.

11. M.J. Gray, The Liquid Chromatographer 7 (1981) 3.

12. A.P.G. Kieboom, T. Spoormaker, A. Sinnema, J.M. van der Toorn, and H. van Bekkum, Rec1. Trav. Chim. Pays-Bas 94 (1975) 53.

13. A.P.G. Kieboom, H.M.A. Buurmans, L.K. van Leeuwen, and H.J. van Benschop, Recl. Trav. Chim. Pays-Bas 98 (1979) 393.

14. L.A.Th. Verhaar and B.F.M. Kuster, J. Chromatogr. 210 (1981) 279.

15. J.D. Stevens, Meth. Carbohydr. Chem. 6 (1972) 123.

16. S.J. Angyal and G.S. Bethell, Aust. J. Chem. 29 (1976) 1249.

17. R.S. Tipson and R.F. Brady, Carbohydr. Res. 10 (1969) 549.

18. R.J. Hamilton and P.A. Sewell, Introduction to high performance liquid chromatography, Wiley \& Sons, New York (1977), 1-36. 
This thesis describes investigations in the field of the combi-process: the combined action of an enzyme and a metal catalyst, applied to the preparation of D-mannitol.

Chapter 1. In the introduction the principles and the requirements of the combi-process are explained. The organization of this thesis is given.

Chapter 2. The present commercial production of D-mannitol, a valuable nutritive sweetener, takes place by hydrogenation of 1 : D-glucose/D-fructose mixtures over nickel. The low D-mannitol yield (25-30\%), however, asks for the development of alternative procedures. A literature survey of various production methods is given, including some other possible combinations of known procedures. It is concluded that the simultaneous use of glucose isomerase and copper on silica (combi-process) is a promising procedure for the preparation of D-mannitol from D-glucose or D-glucose/D-fructose syrups.

Chapter 3. D-Fructose and D-fructose/D-glucose mixtures have been hydrogenated in water at $60-80{ }^{\circ} \mathrm{C}$ and $20-75 \mathrm{~kg} / \mathrm{cm}^{2}$ hydrogen with $\mathrm{Ni}, \mathrm{Cu}, \mathrm{Ru}, \mathrm{Rh}, \mathrm{PD}, \mathrm{Os}$, Ir and $\mathrm{Pt}$ as the catalyst metals. The selectivity for D-mannitol formation from D-fructose as well as the selectivity for D-fructose hydrogenation in the presence of D-glucose with silica-supported $\mathrm{Cu}$ as the catalyst are substantially higher than those for the other catalysts investigated.

With $\mathrm{Cu} / \mathrm{SiO}_{2}$ as the catalyst, the hydrogenation of D-fructose is first order with respect to the amount of catalyst and the hydrogen pressure, whereas a shift from first to zero order kinetics occurs from low $(<0.3 \mathrm{M})$ to high $(>0.8$ M) D-fructose concentrations. D-Fructose is preferentiall hydrogenated via its furanose ring forms, presumably by attack of a copper hydride-like species on the anomeric carbon with inversion of configuration. Preferential adsorption of pyranose with respect to furanose forms occurs, whereas the furanose forms show a much higher reactivity. 
The mechanism proposed for the copper-catalyzed hydrogenation explains both the enhanced D-mannitol yield from D-fructose borate esters and the diastereoselectivity of the hydrogenation of seven other ketoses.

Chapter 4. The combination of ${ }^{11} \mathrm{~B}$ and ${ }^{13} \mathrm{C}$ NMR spectroscopy with several model compounds is used in order to elucidate the ester formation between borate and D-mannitol, D-glucitol, D-fructose and D-glucose in aqueous solution at $\mathrm{pH} \quad 6-12$ and $25{ }^{\circ} \mathrm{C}$. Under conditions which are comparable with those applied for the copper-catalyzed hydrogenation, the main borate ester species present are spirocyclic di-esters of borate in which the boron takes part of two 5-membered rings. The overall stability constant for the borate di-ester of D-mannitol, D-glucitol and D-fructose is about two orders of magnitude higher than that of D-glucose. At high carbohydrate/borate ratios D-mannitol shows the selective formation of bis(Dmannitol) 3,4;3'4'-borate, whereas D-glucitol results in a mixture of six different bis(D-glucitol) borate esters involving both 2,3- and 3,4-dihydroxyl moieties. Bis(D-fructose) and bis(D-glucose) borate esters consist of pairs of diastereomers of the $2,3-\beta-$ and $1,2-\alpha$-furanose moieties, respectively.

At low carbohydrate/borate ratios mono-, di- and, sometimes, triborate esters are formed, e.g. a mixture of $\alpha$-D-glucofuranose 1,$2 ; 3,5$-diborate and $\alpha$-D-glucofuranose 1,$2 ; 5,6$-diborate for $D$-glucose and a mixture of $\beta$-D-fructopyranose 1,$2 ; 4,5$-diborate and $\beta$-D-fructopyranose 2,3;4,5-diborate for D-f ructose.

Chapter 5. A survey is given of glucose isomerase (E.C. 5.3.1.5), its sources, its mechanism of isomerization and its data and properties in three different immobilized forms which are commercially available. In addition, the effect of a number of parameters on the activity of immobilized glucose isomerase has been investigated, e.g. hydrogen pressure, $\mathrm{Mg}$ (II) and $\mathrm{Ca}$ (II), transition metal ions, borate and sugar alcohols. Immobilized glucose isomerase, either in its entrapped cell environment or in its purified form, remains suffi- ciently active under the hydrogenation conditions (copper on silica, $70{ }^{\circ} \mathrm{C}$, up to $75 \mathrm{~kg} / \mathrm{cm}^{2}$ hydrogen pressure) to maintain D-glucose and D-fructose equilibrium. Essential additives are a buffering agent (e.g. $\mathrm{CaCO}_{3} ; \mathrm{pH}-7$ ), a magnesium salt (as the $\mathrm{Mg}$ (II) source for the enzyme) and, in the case of the purified enzyme preparation, a chelating agent (EDTA) for the protection of the enzyme against traces of copper ions. D-Glucitol, in contrast to D-mannitol, has some inhibiting effect on the enzyme action. It possesses the right geometry to mimic a D-glucose (or D-fructose) molecule at the active center. The D-glucose/D-fructose equilibrium constant is independent of the total sugar concentration (between $0.2-2.2 \mathrm{M}$ ).

Chapter 6 . The isomerization of $1{ }^{13} \mathrm{C}-\mathrm{D}-\mathrm{g} l$ ucose to an equilibrium mixture of $1-{ }^{13} \mathrm{C}-\mathrm{D}-\mathrm{g} 1 \mathrm{ucose}$ and $1-{ }^{13} \mathrm{C}-\mathrm{D}-\mathrm{f}$ ructose by the enzyme glucose isomerase (E.C. 5.3.1.5) has been followed by ${ }^{13} \mathrm{C}$ NMR spectroscopy. The results show that the $\alpha-D-g l u c o p y r a-$ nose and the $\alpha-D$-fructofuranose form are the reactive species for the enzyme.

Chapter 7. A combi-process involving co-operation of a bio- and a chemo-catalyst has been developed by simultaneous enzymatic interconversion and metal-catalyzed hydrogenation of D-glucose/D-fructose mixtures. High yields of D-mannitol (62-66\%) have been obtained with D-glucose or D-glucose/D-fructose mixtures as the starting material using glucose isomerase immobilized on silica in combination with a copper on silica hydrogenation catalyst (water, $\mathrm{pH} \sim 7,70{ }^{\circ} \mathrm{C}, 50 \mathrm{~kg} / \mathrm{cm}^{2}$ hydrogen, trace amounts of buffer, Mg(II), borate and EDTA). Non-enzymatic isomerization and degradation reactions are negligible under these reaction conditions.

Chapter 8. With respect to the above-mentioned investigations a quantitative HPLC analysis technique has been developed (using RI detection). Sulfonated polystyrene-divinylbenzene resin in the $\mathrm{Ca}$ (II) form as the stationary phase with water as the eluent at $65{ }^{\circ} \mathrm{C}$ gives almost base line separation of sucrose, D-glucose, D-mannose, D-fructose, D-tagatose, D-manni- 
tol, D-psicose and D-glucitol. Retention times and capacity factors have been determined for 44 mono-, di-, trisaccharides and alditols. The HPLC system proved to be stable for 12 months $(6,500$ analysis runs) without any need for regeneration. This allowed the use of an autoinjector overnight and the weekends. Dependent on the complexity of the carbohydrate mixture, analysis times vary from 6 to $60 \mathrm{~min}$.

\section{SAMENVATTING}

In dit proefschrift wordt het onderzoek beschreven aan het combi-proces: de gecombineerde samenwerking van een enzym en een metalkatalysator, toegepast voor de bereiding van D-mannitol.

Hoofdstuk 1. In de inleiding worden het principe van en de eisen aan het combi-proces uitgelegd. Tevens wordt de opbouw van het proefschrift weergegeven.

Hoofdstuk 2. De huidige commerciële productie aan D-mannitol, een wardevolle zoetstof, gebeurt door middel van de hydrogenering van een $1: 1$ mengsel van $D$-glucose en $D$-fructose over een nikkel katalysator. De lage D-mannitol opbrengst vraagt echter om de ontwikkeling van alternatieve werkwijzen. Uit een literatuuroverzicht van de verschillende productiemethodes, inclusief enige combinaties van bekende werkwijzen, kan worden geconcludeerd dat het combi-proces (de gelijktijdige werking van glucose isomerase en koperkatalysator) een veelbelovende werkwijze is voor de productie aan D-mannitol vanuit D-glucose of D-glucose/D-fructose stropen.

Hoofdstuk 3. In waterig milieu van $60-80{ }^{\circ} \mathrm{C}$ en een waterstofdruk van $20-75 \mathrm{~kg} / \mathrm{cm}^{2}$ zijn D-fructose en mengsels van D-fructose en D-glucose over $\mathrm{Ni}, \mathrm{Cu}, \mathrm{Ru}, \mathrm{Rh}, \mathrm{Pd}, \mathrm{Os}$, Ir en $\mathrm{Pt}$ als metaalkatalysator gehydrogeneerd. Zowel de selectiviteit naar D-mannitol uitgaande van D-fructose als de selectiviteit voor de hydrogenering van $D$-fructose in aanwezigheid van D-glucose $z i$ jn voor de $\mathrm{Cu} / \mathrm{SiO}_{2}$ katalysator beduidend hoger dan de gevonden selectiviteiten van de andere onderzochte katalysatoren. De hydrogenering van D-fructose over $\mathrm{Cu} / \mathrm{SiO}_{2}$ is eerste orde in de hoeveelheid katalysator en de waterstofdruk. Er treedt een verschuiving op van eerste naar nulde orde kinetiek gaande van lage $(<0.3 \mathrm{M})$ naar hoge (>0.8 M) D-fructose concentraties. D-Fructose wordt bij voorkeur via zijn furanose ringvormen gehydrogeneerd, waarschijnlijk door de aanval van een koperhydrideachtig deeltje op het anomere koolstofatoom met inversie 
van configuratie. De adsorptiesterkte van de pyranose vormen is hoger dan die van de furanose vormen, de reactiviteit van de furanose vormen daarentegen is aanzienlijk groter dan die van de pyranose vormen. Het voorgestelde mechanisme voor de hydrogenering over koperkatalysator verklaart zowel de verhoogde D-mannitol opbrengst voor de hydrogenering van $\mathrm{D}$-fructose in de aanwezigheid van boraten als de diastereoselectiviteit voor de hydrogenering van zeven andere ketosen.

Hoofdstuk 4. De combinatie van $11_{B}$ en ${ }^{13} \mathrm{C}$ NMR spectroscopie aan diverse modelstoffen is gebruikt om de estervorming tussen boraat en D-mannitol, D-glucitol, D-fructose en D-glucose in waterig milieu bij $\mathrm{pH} 6-12$ en $25{ }^{\circ} \mathrm{C}$ op te helderen. Onder omstandigheden die' vergelijkbaar zijn met de toegepaste hydrogeneringscondities, $z i j n$ de boraatesters hoofdzakelijk aanwezig als spirocyclische di-esters waarin het booratoom deel uitmakt van twee vijfringen. De stabiliteitsconstante voor de boraat di-ester van D-mannitol, D-glucitol en D-fructose is ongeveer honderd keer hoger dan die van D-glucose. D-Mannitol vormt bij hoge koolhydraat/boraat verhoudingen selectief het bis(D-mannitol)3,$4 ; 3^{\prime}, 4^{\prime}$-boraat. In het geval van D-glucitol wordt een mengsel van zes bis(D-glucito1)boraatesters gevormd, waarbij zowel de 2,3- als de 3,4-dihydroxygroepen van het D-glucitol betrokken zijn. Verder worden onder deze omstandigheden het bis( $\beta-D$-fructofuranose $)-(R)$ - en $(S)$ 2,$3 ; 2^{\prime}, 3^{\prime}$-boraat voor het $D$-fructose en het bis( $\alpha-D-g 1$ lucofuranose) $(R)$ - en $(S)-1,2 ; 1^{\prime}, 2^{\prime}$-boraat voor het D-glucose gevormd. Bij lage koolhydraat/boraat verhoudingen worden mono-, di- en soms triboraatesters gevormd, bijvoorbeeld een mengsel van $\alpha-D-g l$ ucof uranose-1,2;3,5-diboraat en $\alpha-D-$ glucofuranose- 1,$2 ; 5,6$-diboraat voor $D$-glucose en een mengsel van $\beta-D$-fructopyranose-2,3;4,5-diboraat en $\beta-D$-fructopyranose-1,2;4,5-diboraat voor $D$-fructose.
Hoofdstuk 5. In een overzicht over drie geimmobiliseerde glucose isomerases (E.C. 5.3.1.5), die commercieel verkrijgbaar zijn, worden achtereenvolgens de bronnen, het mechanisme van de isomerisatie en praktijkeigenschappen behandeld. Tevens wordt het effect van waterstofdruk, $\mathrm{Mg}$ (II) en $\mathrm{Ca}$ (II), overgangsmetaalionen, boraat en alditolen op de activiteit van geĩmmobiliseerd glucose isomerase onderzocht. Geİmmobiliseerde glucose isomerases, hetzij opgesloten in de eigen celomgeving, hetzij in zuivere vorm, blijven voldoende actief onder de condities van het combi-proces $\left(\mathrm{Cu} / \mathrm{SiO}_{2}, 70{ }^{\circ} \mathrm{C}, 50 \mathrm{~kg} / \mathrm{cm}^{2}\right.$ waterstofdruk) om het evenwicht van D-glucose en D-fructose in stand te houden. Een buffer $\left(\mathrm{CaCO}_{3}, \mathrm{pH} \sim 7\right)$, een $\mathrm{Mg}(\mathrm{II})$ bron en, in het geval van een gezuiverd enzympreparaat, een complexerend agens (EDTA) zijn echter noodzakelijk voor het optimaal functioneren van het enzym. D-Glucitol heeft, in tegenstelling tot D-mannitol, enigszins een remmende werking op het enzym. D-Glucitol beschikt over de juiste geometrie om het D-glucose- of het D-fructosemolecuul in het actieve centrum van het enzym na te bootsen. De D-glucose/D-fructose evenwichtsconstante is onafhankelijk van de totale suikerconcentratie $(0.2-2.2 \mathrm{M})$.

Hoofdstuk 6. Met behulp van ${ }^{13} \mathrm{C}$ NMR spectroscopie is de enzymatische isomerisatie van $1-{ }^{13} \mathrm{C}-\mathrm{D}-\mathrm{glucose}$ naar het evenwichtsmengsel van $1-{ }^{13} \mathrm{C}-\mathrm{D}-\mathrm{g} 1 \mathrm{ucose}$ en $1-{ }^{13} \mathrm{C}-\mathrm{D}$-f ructose onderzocht. De reactieve anomeren voor het enzym glucose isomerase (E.C. 5.3.1.5) blijken $\alpha-D-g l$ ucopyranose en $\alpha-D-$ fructofuranose te $z i j n$.

Hoofdstuk ?. De samenwerking tussen een bio- en een chemo-katalysator wordt in het combi-proces toegepast voor de gelijktijdige enzymatische interconversie en metaalgekatalyseerde hydrogenering van D-glucose/D-fructose mengsels. Het combi-proces leidt tot hoge opbrengsten aan D-mannitol (62-66\%) met D-glucose of mengsels van D-glucose en D-fructose als grondstoffen. Deze hoge opbrengst wordt bereikt door gebruik te maken van gezuiverd glucose isomerase geīmmobiliseerd op silica en koper op silica als hydrogeneringskatalysator. De optimale procescodities zijn een temperatuur 
van $70{ }^{\circ} \mathrm{C}$, een waterstofdruk van $50 \mathrm{~kg} / \mathrm{cm}^{2}$ en een $\mathrm{pH}$ van 7. Tevens moeten er sporen van een buffer, $M g(I I)$-zout, boraat en EDTA aan de waterige oplossing toegevoegd worden. Onder deze omstandigheden zijn de niet-enzymatische isomerisatie- en afbrakreacties te verwaarlozen.

Hoofdstuk 8. Voor het onderzoek aan het combi-proces is een kwantitatieve HPLC analysetechniek ontwikkeld. Door gebruik te maken van een gesulfoneerde polystyreen-divinylbenzeenhars in de $\mathrm{Ca}(\mathrm{II})$-vorm als stationaire fase bij $65^{\circ} \mathrm{C}$ met water als eluent, kan een mengsel van sucrose, D-glucose, D-mannose, D-fructose, D-tagatose, D-mannitol, D-psicose en D-glucitol zo goed als tot basislijn gescheiden worden. De retentietijden en de capaciteitsfactoren van 44 mono-, di-, trisacchariden en alditolen zijn bepaald. Het HPLC systeem blijkt gedurende een periode van 12 maanden (6500 analyses) stabiel te zijn. Regeneratie van de HPLC-kolom is niet noodzakelijk. Het gebruik van een auto-injector op het HPLC systeem gedurende de nachten en in het weekend is geen probleem. De analysetijd varieert afhankelijk van de ingewikkeldheid van het koolhydratenmengsel van 6 tot 60 minuten. 
GURRICUIUM VITAE

Michiel Makkee werd op 21 februari 1954 geboren te 's-Gravenhage. Na het behalen van het HBS-B diploma aan het Maerlant Lyceum te 's-Gravenhage, werd in 1972 begonnen met de studie voor scheikundig ingenieur aan de Technische Hogeschool Delft. Na een afstudeerperiode onder leiding van prof.dr.ir. H. van Bekkum en prof.ir. J.A. Roels werd deze studie in september 1980 met het doctoraal examen afgesloten. Per 1 oktober 1980 trad hij in dienst van de Nederlandse Organisatie voor Zuiver Wetenschappelijk Onderzoek (Z.W.O.) als wetenschappelijk assistent. Het promotieonderzoek werd onder leiding van prof.dr.ir. H. van Bekkum en dr.ir. A.P.G. Kieboom in het Laboratorium voor Organische Chemie van de Technische Hogeschool Delft uitgevoerd. Sinds 1 april 1984 is hij werkzaam bij Esso Chemie b.v. te Rotterdam. 


\section{DANKWOORD}

Graag wil ik mijn dank betuigen aan allen die aan de totstandkoming van dit proefschrift hebben bijgedragen en in het bijzonder:

- Herman van Bekkum en Tom Kieboom, mijn promotoren, voor de deskundige en enthousiaste wijze waarop $z i j$ mij tijdens het onderzoek hebben begeleid;

- Ernst Wurtz voor het assisteren bij alle autoclaafproeven en voor het oplossen van de vele experimentele problemen;

- Willem Jongeleen voor het snelle en accurate tekenen van de talloze figuren en de posters;

- Mieke van der Kooij-van Leeuwen voor het met grote snelheid en nauwgezetheid verzorgen van het typewerk en de lay-out van dit proefschrift;

- Jan Maarten de Bruijn voor de waardevolle discussies tijdens mijn verblijf op de T.H.;

- Fred van Rantwijk en Kees Olieman voor de deskundige aanwijzigingen voor de bediening van hun H.P.L.C.-troetelkinderen;

- Joop Peters en Anton Sinnema voor het opnemen van de talloze MMR spectra;

- Joop Roels voor zijn stimulerende begeleiding in de beginfase van het onderzoek. 